


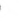








\section{THE ENGLISH WORKS OF}

GEORGE HERBERT

\section{IN THREE VOLUMES}

VOLUME III 




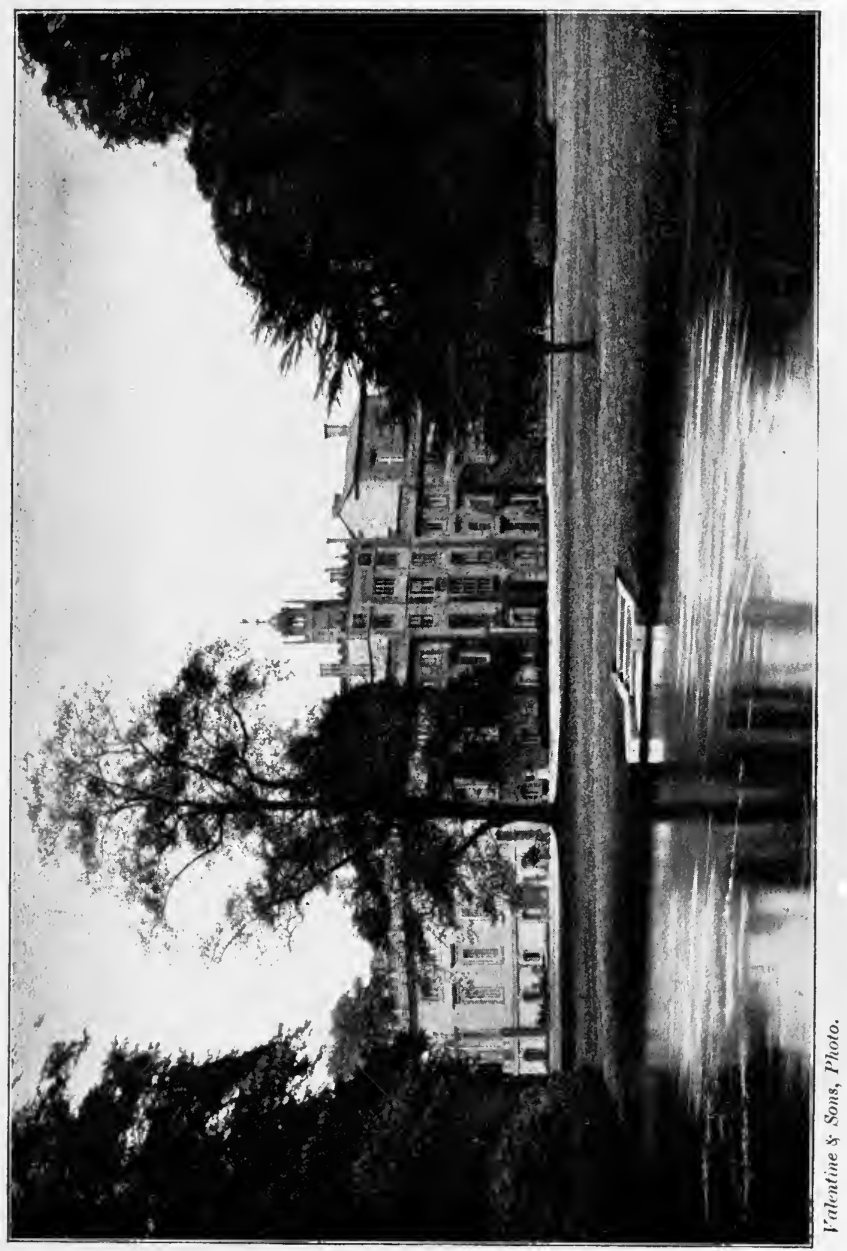




\title{
THE ENGLISH WORKS OF
}

\section{George 垩erbert}

NEWLY ARRANGED AND ANNOTATED AND CONSIDERED IN RELATION TO HIS LIFE

BY GEORGE HERBERT PALMER

\author{
VOLUME III \\ BEMERTON POEMS \\ W
}

BOSTON AND NEW YORK

HOUGHTON MIFFLIN AND COMPANY

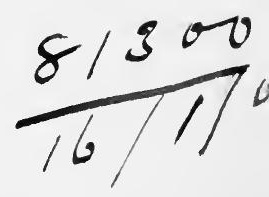
$\mathrm{MDCCCCV}$ 
COPYrIGHT 1905 BY GEORGE HERBERT PALMEr
ALL RIGHT RESERVED
Published October 1905

$$
\begin{aligned}
& P R \\
& 3507 \\
& A 2 P 3 \\
& V .3
\end{aligned}
$$




\section{TABLE OF CONTENTS}

VOLUME III

\begin{tabular}{lr}
\multicolumn{1}{l}{ GROUP } & PAGE \\
VII. THE HAPPY PRIEST & 1 \\
VIII. BEMERTON STUDY & 65 \\
IX. RESTLESSNESS & 169 \\
X. SUFFERING & 241 \\
XI. DEATH & 309 \\
XII. ADDITIONAL AND DOUBTFUL POEMS & 345 \\
VARIATIONS OF THE MANUSCRIPTS & 433 \\
INDEX TO POEMS & 439
\end{tabular} 



\section{LIST OF ILLUSTRATIONS}

\section{VOLUME III}

Wilton House

FRONTISPIECE

Herbert's Subscription at Institution page 6

Herbert's Subscription at Ordination 64

Rectory at Bemerton 74

Garden and River at Bemerton 168

Exterior of Bemerton Church 240

INTERIOR OF BeMERTON ChURCh 308

Fugaleston Church 344.

Salisbury Cathedral 432 



\section{VII}

\section{THE HAPPY PRIEST}





\section{PREFACE}

TTITH this Group begins the last and briefest period of Herbert's life, a period remarkable for its productivity. It extends from his coming to Bemerton in 1630 to his death in 1633. In it The Country Parson was written and most of the eighty-six poems which here follow. No poem printed in Groups VII-XI is found in the Williams Manuscript, which I have elsewhere shown to have been probably drawn up about 1628. Some of these poems may proceed from the last years of the Crisis, but as they contain no reference to the struggle there described, I have not included them in that Group. Some, especially among those printed under the heading Bemerton Study, were probably written at least in part during the Cambridge years, and then, either by accident or design, were not copied into the manuscript lent to Ferrar in 1627-9. But substantially the poems of these five Groups are Bemerton poems. Their omission from the Williams Manuscript is prima facie evidence of date. Nearly all of them, outside Group VIII, contain allusions to the priestly character of the writer. Emotional depth and individual experience will be found in them to a degree unknown in the Cambridge period, and 
they very generally look back to a past different . from that in which their author is now living.

The beginning of the Bemerton life brought to Herbert a joyful sense of attainment. The hopes of many years seemed now about to be realized. The great deed was done. He was no longer cumbered with political, social, or scholarly ties. He and God were to be alone, and his one interest henceforth was to be the priestly office. He set himself with characteristic energy to search out all the subtle significance which his present tasks might contain. His life should be as intellectually ordered, as coherent, as beautiful, as compact with rich suggestion, as his verse had been before. He codified his work; he studied from day to day what were the best ways of performing each petty portion of his stately office.

Walton gives a long account of Herbert's elaborate rationalization of the English ritual. This account is on its face open to doubt. How much of it proceeds from Herbert's mind, and how much from Walton's, is not clear. Walton had no acquaintance with Herbert, and this argumentative piece of history was written long after Herbert's death. Walton's Life, like that by Oley, was obviously intended to serve the useful purpose of an Anti-Puritan tract. But after all deductions, the argumentation seems well in keeping with Herbert's general temper. It is ever his way to make the most of what he finds at hand. He asks few 
ultimate questions, but turns all that tradition hands down to him into something rich and meaningful. Throughout this account he justifies the services of his Church because of their reasonableness, and not because they are authoritatively prescribed; and this is his method in his poems and The Country Parson. There, as here, he grounds the practices of the collective Church on the needs of the individual soul. On the whole, then, I believe Walton's pages on ritual may be accepted as a fair account of Herbert's disposition during the Bemerton years. He tried to bring into action and fill with ingenious, independent, and reverent intelligence all the resources of his little world. By this poetic development of ritual he sought to do for his people what he was at the same time doing for himself in The Country Parson. He "made it appear to them that the whole Service of the Church was a reasonable, and therefore an acceptable, Sacrifice to God." Always to his mind the way to render life glorious was to stuff every portion of it with thought, and delightedly to detect compacted reason where the dull mind contents itself with seeing only plain fact.

The present Group of poems is the expression of exuberant joy in at last reaching a long hoped for good. Few other Groups have so lyric a quality. After some study of the conditions of the priesthood, he sees that these are all summed up in the priest's abandonment of everything that can be 
called his own, and in his full absorption into the life of his Master. Such union, the realization of thoughts of love which had possessed him for many years, throws him into an intellectual ecstasy, and song after song is poured out expressing his delight. The ordinances of the Church, especially those connected with the Holy Supper, get a new meaning. The closing day is sacramental, and all the world resounds with God's praise. 


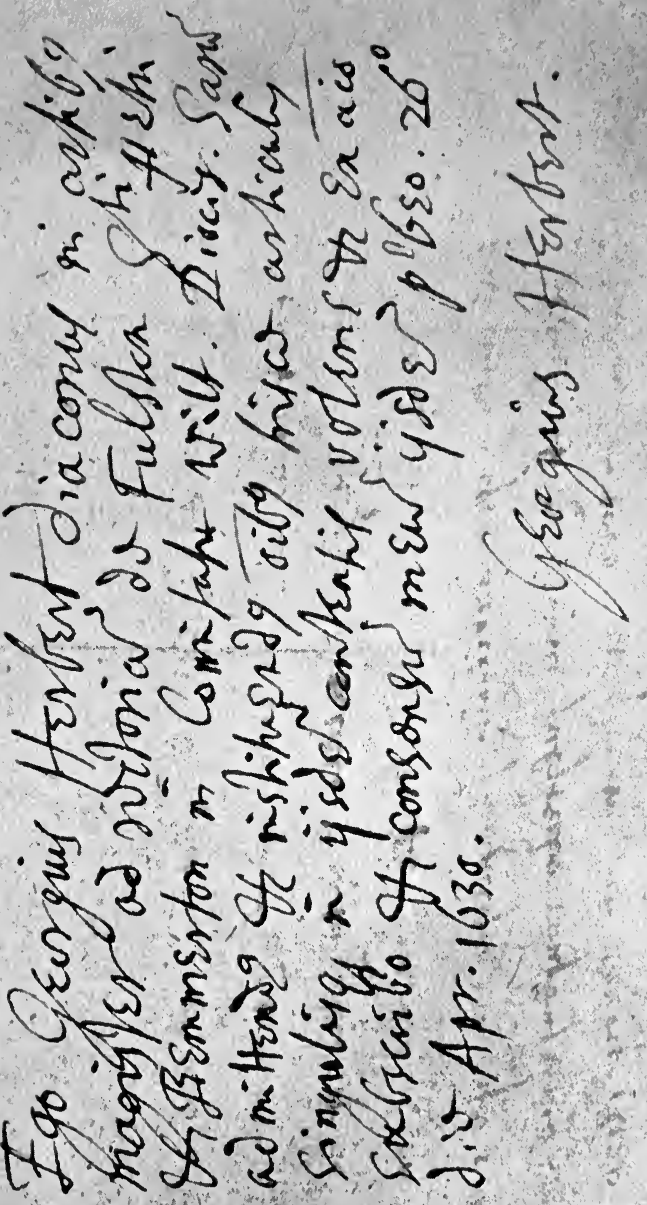



THE HAPPY PRIEST 


\section{Date:}

Not found in W. The first happiness either of taking orders or of settling at Bemerton.

Metre:

Used also in The Rose, II, 389. SubJect :

Having Thee, I have all.

Stanza i, What life will then be.

Stanza ii, What He will then be.

Stanza iii, What I shall then be.

Notes :

1. John xiv, 6.

2. A way or road usually deprives us of breath.

4. Ed. 1633 reads And such a, throwing the line out of rhythm and out of conformity to the plan of the poem. I substitute the reading of $B$. and of the later editions.

6. Thou art not only the feast, but the way to it: Country Parson, XXII. The same rhyme occurs again in FAITH, II, 233, 1. 6 and 8.

7. A feast, unlike common feasts, more enjoyable the longer it continues.

8. A strength which makes him who approaches strong.

10. As none can demand. Cf. Praise, II, 397, 1. 4; The Method, III, 197, 1. 6.

11. Romans viii, 35 . 


\section{THE CALL}

Coмe, my Way, my Truth, my Life:

Such a Way as gives us breath, Such a Truth as ends all strife, Such a Life as killeth death.

Come, my Light, my Feast, my Strength: 5 Such a Light as shows a feast, Such a Feast as mends in length, Such a Strength as makes his guest.

Come, my Joy, my Love, my Heart:

Such a Joy as none can move,

Such a Love as none can part, Such a Heart as joyes in love. 
INTRODUCTORY :

"When at his Induction he was shut into Bemerton Church, being left there alone to Toll the Bell (as the Law requires him) he staid so much longer than an ordinary time that his Friend Mr. Woodnot looked in at the Church-window and saw him lie prostrate on the ground before the Alter; at which time and place (as he after told Mr. Woodnot) he set some Rules to himself for the future manage of his life; and then and there made a vow to labour to keep them:" Walton's Life.-AARoN well illustrates the exquisite art of Herbert in allowing thought to dictate form. The standard of the priesthood being one, is fixed in five rhyming words: in his own head and heart the priest must be sound; from him music must go forth; it is his work to find rest for the sinful; his dress or exterior must express an inner purity. In successive stanzas, all having the same fixed rhyme, this scheme tests the divergent natures found in man. Swinburne, in his poem Eight Years Old, similarly employs a fixed set of rhymes for all the stanzas.

DATE:

Not found in W. Probably written after ordination at Bemerton.

Metre:

Unique.

SubJeCt:

The true priest. 


\section{AARON}

Holinesse on the head,

Light and perfections on the breast, Harmonious bells below, raising the dead To leade them unto life and rest;

Thus are true Aarons drest.

Profanenesse in my head, Defects and darknesse in my breast, A noise of passions ringing me for dead Unto a place where is no rest;

Poore priest thus am I drest. 
Notes:

1. Exodus xxviii, 36.

2. Light and perfections = Urim and Thummim, Exodus xxviii, 30.

3. In Exodus xxviii, 33-35, the robe of the High Priest is described. On its lower hem it had rows of bells and pomegranates. Herbert refers to Aaron's bell again in DecaY, III, 115, 1. 10.

8. Noise is again contrasted with music in THE FAMILIE, III, 185, 1. 1.

13. Live $=$ alive.

19. Old man. Colossians iii, 9. Vaughan in his Repentance rewrites thus:

"Profaneness on my tongue doth rest,

Defects and darkness in my breast;

Pollutions all my body wed,

And even my soul to Thee is dead;

Only in Him on Whom I feast

Both soul and body are well drest." 
Onely another head

I have, another heart and breast, Another musick, making live not dead, Without whom I could have no rest;

In him I am well drest.

Christ is my onely head,

My alone onely heart and breast, My onely musick, striking me ev'n dead,

That to the old man I may rest,

And be in him new drest.

So holy in my head,

Perfect and light in my deare breast,

My doctrine tun'd by Christ, (who is not dead, But lives in me while I do rest,)

Come people! Aaron's drest. 
Date:

Not found in W. Salisbury Cathedral is noted for the number of its windows, which are said to be as many as the days of the year.

Metre:

Unique.

SUBJECT :

The preacher's heavenly doctrine must shine through his own life before it can affect those who would see God.

Notes:

2. Brittle. So The Priesthood, II, 373, 1. 11.

3. Though Herbert often regards man as God's Temple (Man, II, 215, 1. 1-6; The Church-Floore, III, 167; Sron, III, 265), the word occurs in his poems only here, in The Church-Porch, II, 63, 1. 423, Sion, III, 265, 1. 2, The Church Miliuant, III, 375, 1. 225, and in the doubtful poem THE Convert, III, 397, 1. 18. It occurs again in his letter to his mother (1622), I, 405: God intends the soul to be as a sacred temple for Himself to dwell in. And in The Country Parson, XXI, the parson is to build up this knowledge to a spirituall Temple.

6. Anneal. Glass which has been painted is afterwards fired or annealed in order to fix the color. So Love-Joy, III, 163, 1. 3. 


\section{THE WINDOWS}

LoRD, how can man preach thy eternall word?

$\mathrm{He}$ is a brittle crazie glasse,

Yet in thy temple thou dost him afford

This glorious and transcendent place

To be a window, through thy grace. 5

But when thou dost anneal in glasse thy storie,

Making thy life to shine within

The holy Preachers, then the light and glorie

More rev'rend grows, and more doth win;

Which else shows watrish, bleak, and thin.

Doctrine and life, colours and light, in one

When they combine and mingle, bring

A strong regard and aw; but speech alone

Doth vanish like a flaring thing,

And in the eare, not conscience ring. 15 
INTRODUCTORY :

The true ground of confidence.

Date:

Not found in W.

Metre:

Of seventeen sonnets, six - like this - are in the Shakespearian form.

SubJeCT:

"It is God which worketh in you both to will and to do of his good pleasure:" Philippians ii, 13. Notes:

1. Strict decree, Matthew v, 48.

6. Was, instead of is, indicating quotation.

13. 1 Corinthians Xv, 22. 


\section{THE HOLDFAST}

I THREATNED to observe the strict decree Of my deare God with all my power and might.

But I was told by one it could not be, Yet I might trust in God to be my light. Then will I trust, said I, in him alone.

Nay, ev'n to trust in him was also his;

We must confesse that nothing is our own.

Then I confesse that he my succour is.

But to have nought is ours, not to confesse

That we have nought. I stood amaz'd at this,

Much troubled, till I heard a friend expresse

That all things were more ours by being his. What Adam had, and forfeited for all, Christ keepeth now, who cannot fail or fall. 


\section{INTRODUCTORY :}

For five other Psalms which are supposed to have been translated by Herbert, see III, 407-419.

\section{Date:}

Not found in W.

Metre:

Used again in Submission, III, 205. 


\section{THE 23 PSALME}

The God of love my shepherd is, And he that doth me feed. While he is mine and I am his, What can I want or need?

He leads me to the tender grasse,

Where I both feed and rest,

Then to the streams that gently passe;

In both I have the best.

Or if I stray, he doth convert

And bring my minde in frame. 10

And all this not for my desert,

But for his holy name. 
15. Thy rod is with me.

21-24. In this stanza one sees how sweetly and simply Herbert could write when he designed to do so. 
Yea, in death's shadie black abode

Well may I walk, not fear;

For thou art with me, and thy rod

To guide, thy staffe to bear.

Nay, thou dost make me sit and dine

Ev'n in my enemies' sight.

My head with oyl, my cup with wine Runnes over day and night.

Surely thy sweet and wondrous love Shall measure all my dayes;

And as it never shall remove, So neither shall my praise. 
INTRODUCTORY:

"The same night that he had his Induction he said to Mr. Woodnot: I have this day taken Jesus to be my Master and Governour; and I am so proud of his service that I will always observe and obey and do his Will, and alwaies call him Jesus my Master:" Walton's Life. - "To testifie his independencie upon all others, and to quicken his diligence in this kinde, he used in his ordinarie speech, when he made mention of the blessed name of our Lord and Saviour, Jesus Christ, to adde, My Master:" Ferrar, Preface to The Temple. Cf. also John xiii, 13. Date:

Not found in W.

Metre:

Used only here. The first and last line of each stanza rhyme on the same word, thus assisting the suggestion of a pervasive perfume.

SubJect :

Love should yield a reciprocal fragrance, both to lover and to loved.

\section{Notes:}

3. Gray amber, a secretion of the spermaceti whale, is found floating in lumps upon the sea, and is much prized in perfumery. Milton refers to it in his "Amber scent of odorous perfume:" Samson Agonistes, 1. 720. See, too, Sir T. Browne, Vulgar Errors, Bk. III, ch. xxvi.

6. So The Banquet, III, 55, 1. 24. 


\section{THE ODOUR}

(2 CORINTHIANS II, 15)

How sweetly doth My Master sound! My Master!

As Amber-greese leaves a rich sent Unto the taster,

So do these words a sweet content, An orientall fragrancie, My Master.

With these all day I do perfume my minde,

My minde ev'n thrust into them both,

That I might finde

What cordials make this curious broth, This broth of smells, that feeds and fats my minde.

My Master, shall I speak? $\mathrm{O}$ that to thee 11 My servant were a little so, As flesh may be,

That these two words might creep and grow

To some degree of spicinesse to thee! 
16. Pomander (more fully described in The Banquet, III, $55,1.25=$ a scent-ball, which when warmed in the hand or crushed (1. 20) yields odor. Shakespeare mentions it among a lady's trinkets; Winter's Tale, iv, 3: "A ribbon, glass, pomander, brooch.” And Bacon, Nat. Hist. Cent. 9, among medical appliances: "They have in physick use of pomanders and knots of powders for drying of rheums, comforting of the heat, provoking of sleep, \&c." In short, it served the double purpose of the modern smelling-bottle.

17. That fragrance which formerly attended my addresses to thee would now be reflected back from thee, and thus gain a double potency.

22. An uneven line is rare in Herbert.

25. Breathing =emission. 
Then should the Pomander, which was before

A speaking sweet, mend by reflection And tell me more;

For pardon of my imperfection

Would warm and work it sweeter then before.

For when My Master, which alone is sweet And ev'n in my unworthinesse pleasing, Shall call and meet

My servant, as thee not displeasing,

That call is but the breathing of the sweet. 25

This breathing would with gains by sweetning me (As sweet things traffick when they meet) Return to thee;

And so this new commerce and sweet Should all my life employ and busie me. 
Date:

Not found in W.

Metre:

UNIQUE.

SUBJECT:

A poem is the utterance of feeling; perfect, according to the completeness with which that feeling is expressed.

Notes:

2. Catches, proverbs, brief phrases saturated with meaning, frequently run in Herbert's mind. So, My Master, in The Odour, III, 23; Less then the least of all thy mercies, in The Posie, III, 29; Thou shalt answer, Lord, for me, in THE QUIP, III, 33; My God and King, in ANTIPHoN, III, 63; Thou art still my God, in The Forerunners, III, 317.

10. Campion in the Preface to his Divine and Moral Songs (1613) prettily writes: “In these English airs I have chiefly aimed to couple my words and notes lovingly together; which will be much for him to do that hath not power over both."

14. Behinde=lacking. So L'Evvor, III, 381, 1. 16.

15. In kinde $=$ according to the true nature of a hymn. Cf. Love, II, 85, 1. 25, and Nature, II, 303, 1. 10.

20. Similar cases where feeling may be conceived as interfering with rhyme are the last lines of JoRDAN, II, 89; The Sacrifice, II, 143, 1. 215; Deniall, II, 299; GrIEF, III, 323. 


\section{A TRUE HYMNE}

Mr joy, my life, my crown!

My heart was meaning all the day

Somewhat it fain would say;

And still it runneth mutt'ring up and down

With onely this, My joy, my life, my crown.

Yet slight not these few words.

If truly said, they may take part

Among the best in art.

The finenesse which a hymne or psalme affords

Is when the soul unto the lines accords.

He who craves all the minde, And all the soul, and strength, and time,

If the words onely ryme,

Justly complains that somewhat is behinde To make his verse, or write a hymne in kinde.

Whereas if th' heart be moved,

Although the verse be somewhat scant,

God doth supplie the want.

As when th' heart sayes (sighing to be approved)

$O$, could I love! and stops: God writeth, Loved. 


\section{INTRODUCTORY :}

Posie here means not a bunch of flowers, as in LrFe, III, 321, 1. 1, but a motto, as in Mrserie, II, 257, 1. 69. In this sense posie is a shortened form of poesie, and is sometimes spelled so by old writers. It is regularly used of inscriptions on glass, and loveverses engraved in rings. I append a few of the latter which I have met in old authors: I seek to be not thine but thee; There is a time; Caught and content; Let us be one till we are none; I would be glad if you I had; Not too fast, but to last; To live in love I love to live; Once mine, always thine; There is no other, and I am he, That loves no other, and thou art she; $M y$ joy $I$ do enjoy; Thy death is mine, my life is thine. Shakespeare uses posie in the same sense as Herbert. In The Merchant of Venice, v. 1, Gratiano says he had a ring from his mistress,

"Whose posy was

For all the world like cutler's poetry Upon a knife, Love me and leave me not."

A notable revival of posie in its ancient sense is that of Browning in his Introduction to The Ring and the Book. After stating the facts which give form to the Ring, he writes: "A ring without a posy, and that ring mine?" and so appends the love-verses of the Invocation. 


\section{THE HAPPY PRIEST}

\section{THE POSIE}

\section{LET wits contest,}

And with their words and posies windows fill.

Lesse then the least

Of all thy mercies, is my posie still. 
Just before his death, when Herbert sent his poems to Ferrar, he said: I and this book (The TeMPLE) are less than the least of God's mercies: Walton's Life. - "We conclude all with his own Motto, with which he used to conclude all things that might seem to tend any way to his honour: Lesse then the least of God's mercies:" Ferrar's Preface to The Temple.

Date:

Not found in W.

Metre:

Unique.

SubJect:

The lover's delight in his own unworthiness. Notes:

3. Cf. Genesis xxxii, 10, with Ephesians iii, 8. 9, 10. Cf. the two Jordans, II, 87 and 91. 
This on my ring,

This by my picture, in my book I write.

Whether I sing,

Or say, or dictate, this is my delight.

Invention rest,

Comparisons go play, wit use thy will. $\quad 10$

Lesse then the least

Of all God's mercies, is my posie still. 


\section{INTRODUCTORY :}

Quip =quid pro quo, a repartee, retort, or homethrust (1. 24), as in Shakespeare's "Quip modest," As You Like It, v, 4. So, too, Lyly, Campaspe, III, 2 .

“Ps. Why, what's a quip?

"Ma. Wee great girders call it a short saying of a sharpe wit, with a bitter sense in a sweet word."

Vaughan imitates this poem in The Ornament. DAte:

Not found in W.

Metre:

Used also in The Quidditie, II, 97.

\section{SUbJect :}

The same that Herbert has often treated in earlier periods of his career, - in The Quidditie, II, 97; The World, II, 225; The Pearl, II, 381. He recounts the appeals that Beauty, Pleasure, Ambition, Wit, have made, calling him from that service of God which he still feels to be a sufficient offset to them. "In this time of his decay he would often speak to this purpose: I now look back upon the pleasures of my life past, and see the content I have taken in beauty, in wit, in musick, and pleasant Conversation, are now all past by me like a dream, or as a shadow that returns not, and are now all become dead to me, or I to them:" Walton's Life. 


\section{THE QUIP}

The merrie world did on a day

With his train-bands and mates agree

To meet together where I lay,

And all in sport to geere at me.

First, Beautie crept into a rose;

Which when I pluckt not, Sir, said she, Tell me, I pray, whose hands are those?

But thou shalt answer, Lord, for me. 
Notes:

2. Train-bands=militia, soldiery; here, organized society.

7. Why do you not clutch at beauty? So, too, in THE Collar, III, 213, 1. 18.

8. The Prayer-Book version of Psalm xxxviii, 15, reads: "In thee, $O$ Lord, have I put my trust; thou shalt answer for me, O Lord, my God."

9. To Herbert money is not a serious temptation. His most important poem on it is Avarice, III, 113. He has also a few general precepts about it in THE Church-Porch, II, 33, 35, 1. 151-180, and occasional mention elsewhere.

15. I do not understand this to mean: He granted me only a glimpse; but, He declared that a person of my dull life could only half perceive what glory is.

23. Some late editions print Thine, with a capital, as if referring to God, and $I$ to man. As printed in ed. 1633, the overwhelming reply to every temptation promising gain is God's voice, saying: "I am thine. What gain is comparable?" 
Then Money came, and chinking still, What tune is this, poore man? said he, 10

I heard in Musick you had skill. But thou shalt answer, Lord, for me.

Then came brave Glorie puffing by In silks that whistled, who but he?

He scarce allow'd me half an eie.

But thou shalt answer, Lord, for me.

Then came quick Wit and Conversation, And he would needs a comfort be, And, to be short, make an oration. But thou shalt answer, Lord, for me. 20

Yet when the houre of thy designe

To answer these fine things shall come, Speak not at large, say, I am thine; And then they have their answer home. 
Date:

Not found in W.

METRE:

Unique. Throughout the poem only two rhymes are used, - mine, thine, and more, restore.

\section{SUBJECT:}

"Either was the other's mine." Shakespeare's The Phoenix and the Turtle, 1. 36. The subject requires that this poem shall have but two stanzas,-reporting Me and Thee,- that these two shall be fully identical in sense and sound, and only distinguishable through being approached from opposite points of view. This thought of "making two one" (The Search, III, 223, 1. 60) is also found in Judgement, II, 271, 1. 15; Artillerie, II, 363, 1. 30; The Holdfast, III, 17, 1. 12.

\section{Notes:}

1. Song of Solomon ii, 16.

6. Advantage=addition, like with gains, of THE Odour, III, 25, 1. 26. Cf. Shakespeare, King John, iii, 3:

"There is a soul counts thee her creditor, And with advantage means to pay thy love."

'This line forms the turn in each stanza; cf. 1. 16.

7. Being mine $=$ a verbal noun, with this as its adjective.

13. Then=than. 


\section{CLASPING OF HANDS}

LoRD, thou art mine, and I am thine, If mine I am; and thine much more Then I or ought or can be mine.

Yet to be thine doth me restore;

So that again I now am mine,

And with advantage mine the more. Since this being mine brings with it thine,

And thou with me dost thee restore.

If $I$ without thee would be mine,

I neither should be mine nor thine.

Lord, I am thine, and thou art mine;

So mine thou art that something more

I may presume thee mine then thine.

For thou didst suffer to restore

Not thee, but me, and to be mine,

And with advantage mine the more.

Since thou in death wast none of thine,

Yet then as mine didst me restore.

$O$ be mine still! Still make me thine!

Or rather make no Thine and Mine! 
INTRODUCTORY :

Herbert generally uses Paradise in this sense, referring to a garden, and primarily to the Garden of Eden. The only passages, I believe, in which the word is used in the sense of Heaven, are: SUNDAY, II, 179, 1. 56, The Flower, III, 307, 1. 23 and 49, and Perseverance, III, 395, 1. 10.-The CounTry Parson (XXXII) is to dresse and prune them, and take as much joy in a straight-growing childe or servant as a Gardiner doth in a choice tree.

Date:

Not found in W.

Metre:

Used also in Trinitie-Sunday, II, 161.

SubJect:

The careful pruning of the divine husbandman symbolized by the elimination of letters from a rhyme, - possibly suggested to Herbert by the trimming of trees in the artificial gardens of his time. Notes:

2. Thy trees. He writes as if he were already a priest. He alludes to the ordering of gardens again in SuNDAY, II, 177, 1. 27, and The FAMILIE, III, 185, 1. 12.

10. Spare probably means refrain from, as in GidDINESSE, III, 129, 1. 12, and elsewhere. The rhyme with are occurs in The British ChURCh, III, 101, 1. 10.

15. Touch=attain. So Donne, Forbidding Mourning, 1. 36: "And makes me end where I begun." 


\section{PARADISE}

I BLESSE thee, Lord, because I G R o w Among thy trees, which in a $\mathrm{R}$ ow To thee both fruit and order ow.

What open force or hidden C H A R M Can blast my fruit, or bring me H A RM, 5 While the inclosure is thine $A R M$ ?

Inclose me still for fear I s T A RT. Be to me rather sharp and $\mathbf{T A R} T$ Then let me want thy hand and A RT.

When thou dost greater judgements S P A R E, And with thy knife but prune and PARE, Ev'n fruitfull trees more fruitfull A R E.

Such sharpnes shows the sweetest FREND, Such cuttings rather heal then $R E N D$, And such beginnings touch their EN D. 15 


\section{DAte:}

Not found in W.

Metre:

Unique.

SUBJECT:

Grant - Thou who hast already granted so much

- grant rest in thyself and thankfulness.

"Would I could wish my wishes all to rest, And know to wish the wish that were the best!"

A. H. Clough's Love is Fellow-Service.

Notes:

2. Notes and Queries for November 2, 1850, quotes Shakespeare, 2 Henry VI, i, 1 :

"O Lord, that lends me life, Lend me a heart replete with thankfulness!"

13-16. A reckoning of what it would come to.

16. And though it is already much, keeps coming for more. 


\section{GRATEFULNESSE}

Thou that hast giv'n so much to me,

Give one thing more, a gratefull heart.

See how thy beggar works on thee By art.

He makes thy gifts occasion more, And sayes, If he in this be crost, All thou hast giv'n him heretofore

Is lost.

But thou didst reckon, when at first

Thy word our hearts and hands did crave, What it would come to at the worst

To save:

Perpetuall knockings at thy doore, Tears sullying thy transparent rooms, Gift upon gift, much would have more, 15 And comes. 
17. Thou wentst on, so Even-Sona, III, 61, 1. 17.

19. Sion, III, 265, 1. 18.

22. Cf. Donne, A Litanie, xxiii, 1:

$$
\text { To Thee }
$$

A sinner is more music when he prays Than spheres' or angels' praises be."

27. In Ungratefulnesse, II, 245, 1. 26, we learn that the only thing God demands of us is a grateful heart. This poem shows how even this must be accepted from Him.

30. Days of omission, containing no blessing. 
This notwithstanding, thou wentst on And didst allow us all our noise. Nay, thou hast made a sigh and grone Thy joyes.

Not that thou hast not still above Much better tunes then grones can make, But that these countrey-aires thy love Did take.

Wherefore I crie and crie again, 25

And in no quiet canst thou be Till I a thankfull heart obtain

Of thee.

Not thankfull when it pleaseth me, As if thy blessings had spare dayes, 30 But such a heart whose pulse may be Thy praise. 
INTRODUCTORY :

Two other poems with this title are given, II, 95, and 397.

DATE:

Not found in W.

Metre:

Unique.

SubJECT:

Praise of God for his watchful efficiency. Notes:

1. Mean =intend, aim at, - so Justice, III, 253, 1. 9.

5. Wring. So in Love Unknown, III, 179, 1. 17.

6. Cf. the refrain of Praise, II, 95.

9. Cf. The Elixer, II, 99, 1. 8.

13. $O n=$ against, adversely to.

15. Is Herbert here remembering the Chain of Zeus?

Homer, Iliad, VIII, 19-27.

17. Exodus xiv, 25. 


\section{PRAISE}

LoRD, I will mean and speak thy praise, Thy praise alone.

My busie heart shall spin it all my dayes;

And when it stops for want of store, Then will I wring it with a sigh or grone,

That thou mayst yet have more.

When thou dost favour any action,

It runnes, it flies;

All things concurre to give it a perfection.

That which had but two legs before,

When thou dost blesse, hath twelve. One wheel doth rise

To twentie then, or more.

But when thou dost on businesse blow,

It hangs, it clogs;

Not all the teams of Albion in a row

Can hale or draw it out of doore.

Legs are but stumps, and Pharaoh's wheels but logs,

And struggling hinders more. 
22. The sea his shore. So Providence, III, 83, 1. 48.

23. Stint $=$ bounds, restraint.

24. In a letter thanking King James for his book, he says of him: $O$ prudentiam incomparabilem, quae eodem vultu et moderatur mundum et nos respicit.

27. Psalm lvi, 8. Cf. Hope, III, 203, 1. 5.

30. In heaven provision is made for more repentance than I have shown.

33. Old battle-flags hung up within a church. - Which refers to drop, not to eye.

36. Referring back to the bottle of 1.27. A little of God's grief over my sin is weightier than all my own.

38. The pressure promised in 1. 5 .

40. At use =usury, interest. Cf. for the thought, OreDience, II, 387, 1. 42, and AN OfFering, II, 393, 1. 7-9. 
Thousands of things do thee employ In ruling all

This spacious globe: Angels must have their joy,

Devils their rod, the sea his shore,

The windes their stint. And yet when I did call, Thou heardst my call, and more.

I have not lost one single tear.

But when mine eyes

Did weep to heav'n, they found a bottle there

(As we have boxes for the poore)

Readie to take them in; yet of a size

That would contain much more.

But after thou hadst slipt a drop

From thy right eye,

(Which there did hang like streamers neare the top

Of some fair church, to show the sore

And bloudie battell which thou once didst trie) 35

The glasse was full and more.

Wherefore I sing. Yet since my heart, Though press'd, runnes thin,

$O$ that I might some other hearts convert,

And so take up at use good store;

That to thy chests there might be coming in

Both all my praise and more! 
Date:

Not found in W.

Metre:

Used also in the next poem, The Banquet. SUBJECT:

Ho, every one that thirsteth, - whether for food, wine, ease, joy, or love, - come to the banquet and find what will elsewhere be vainly sought. $\mathrm{Cf}$. Isaiah lv, 1.

Notes:

1. Taste $=$ appetite.

4. The Priesthood, II, 375, 1. 27.

8. Whose character wine determines, - as winebibbers, drunkards, - with possibly a play upon the word, i. e. it empties of fineness. Cf. Donne, Anatomie of the World, 37: "Her name defined thee, gave thee form and frame." And The Country Parson, XXVI: One act in these things is bad, but it is the custome and habit that names a glutton.

15. The same thought in Miserie, II, 253, 1. 22.

18. Fright. The terror one would naturally feel at his sin becoming visible is here felt for sin itself. 


\section{THE INVITATION}

Come ye hither all whose taste Is your waste.

Save your cost and mend your fare. God is here prepar'd and drest, And the feast,

God, in whom all dainties are.

Come ye hither all whom wine Doth define,

Naming you not to your good. Weep what ye have drunk amisse,

And drink this,

Which before ye drink is bloud.

Come ye hither all whom pain

Doth arraigne,

Bringing all your sinnes to sight.

Taste and fear not. God is here

In this cheer,

And on sinne doth cast the fright. 
23. Such delight as you have known hitherto.

26. Doves draw the celestial car of Venus.

28. This contrast between divine and human love is expounded at length in Two Sonners, II, 79, and in Love, II, 83.

31. Luke xiv, 13.

36. Where God is, there all people should be. 
Come ye hither all whom joy

$$
\text { Doth destroy, }
$$

While ye graze without your bounds.

Here is joy that drowneth quite

$$
\text { Your delight, }
$$

As a floud the lower grounds.

Come ye hither all whose love

Is your dove,

And exalts you to the skie.

Here is love which, having breath

Ev'n in death,

After death can never die.

Lord I have invited all,

$$
\text { And I shall }
$$

Still invite, still call to thee.

For it seems but just and right

$$
\text { In my sight, }
$$

Where is all, there all should be. 


\section{Date:}

Not found in W.

\section{Metre:}

Used also in the preceding poem, The Invitation. SubJect:

The marvellous delicacy of God's table.

\section{Notes:}

4. Neatnesse (cf. MAN, II, 221, 1. 42, and THE Famile, III, 185, 1. 8) is Herbert's frequent word for refined beauty. Dr. Willmott well quotes Milton's line in his Sonnet to Mr. Lawrence: "What neat repast shall feast us, light and choice?"

13. Sweetnesse here, as usually with Herbert, refers to the smell, not the taste. In five stanzas of the poem it is mentioned.

14. Made a head. We say made headway. Cf. The SACRIFICE, II, 123, 1. 5. 


\section{THE BANQUET}

Welcome sweet and sacred cheer,

Welcome deare!

With me, in me, live and dwell;

For thy neatnesse passeth sight,

Thy delight

Passeth tongue to taste or tell.

O what sweetnesse from the bowl

Fills my soul,

Such as is and makes divine!

Is some starre (fled from the sphere) 10

Melted there,

As we sugar melt in wine?

Or hath sweetnesse in the bread

Made a head

To subdue the smell of sinne;

Flowers, and gummes, and powders giving

All their living,

Lest the enemie should winne? 
19. The starre of the second stanza, the flower of the third.

24. So The Odour, III, 23, 1. 6.

25. Pomander = scent-ball. Cf. The Odour, III, 25, 1. 16.

26. Still $=$ at all times.

31. Cf. Vanitie, II, 357, 1. 13.

34. Took bloud=became man.

35. 2 Samuel xiv, 14. 
Doubtlesse neither starre nor flower Hath the power 20

Such a sweetnesse to impart.

Onely God, who gives perfumes,

Flesh assumes,

And with it perfumes my heart.

But as Pomanders and wood

Still are good,

Yet being bruis'd are better sented,

God to show how farre his love

Could improve,

Here, as broken, is presented.

When I had forgot my birth,

And on earth

In delights of earth was drown'd, God took bloud and needs would be Spilt with me,

And so found me on the ground. 
41. Farre from both the heavenly and the earthly courts.

43. Cf. Praise, II, 95, l. 5.

49. The pitie God has shown in the Incarnation.

50. My theme, as in The Forerunners, III, 317, 1. 11.

51. Lines and life $=$ verse and action, repeated in hands and breath of 1. 53. So, too, The Coldar, III, 211, 1. 4. Deed and storie of Complaining, III, 267, 1. 7 , is similar. 
Having rais'd me to look up,

$$
\text { In a cup }
$$

Sweetly he doth meet my taste. But I still being low and short,

Farre from court,

Wine becomes a wing at last.

For with it alone I flie

To the skie;

Where I wipe mine eyes, and see

What I seek, for what I sue,

Him I view

Who hath done so much for me.

Let the wonder of this pitie

Be my dittie,

And take up my lines and life.

Hearken, under pain of death,

Hands and breath,

Strive in this and love the strife. 
Date:

This poem is not in W., but in place of it appears the poem given, III, 391 .

Metre:

Unique. The stanzas are arranged in pairs, by making the second and eighth lines long.

SubJect:

Eyes, light, and power, and the cessation of all three, equally express the love of God. The poem is divided into two parts, by the employment in the fourth and eighth stanzas of a special rhyming system. The first part shows how little I bring to God; the second, how much He brings to me. Is it fanciful to suggest that the first two stanzas of each part discuss eyes and light; the third power?

Notes:

7. Psalm cxxx, 3. But I am now protected against his gaze.

8. His sonne. The double meaning is expanded and discussed in The Sonne, III, 161.

14. Cf. Nature, II, 303, 1. 9. 


\section{EVEN-SONG}

Blest be the God of love,

Who gave me eyes, and light, and power this day

Both to be busie and to play.

But much more blest be God above

Who gave me sight alone, 5

Which to himself he did denie;

For when he sees my waies, I dy,

But I have got his sonne, and he hath none.

What have I brought thee home

For this thy love? Have I discharg'd the debt 10

Which this dayes favour did beget?

I ranne, but all I brought was fome.

Thy diet, care, and cost

Do end in bubbles, balls of winde;

Of winde to thee whom I have crost, 15 But balls of wilde-fire to my troubled minde. 
17. So Gratefulnesse, III, 43, 1. 17. Possibly still here may have its modern meaning of notwithstanding, instead of its usual meaning in Herbert of always.

18. Cf. Man, II, 221, 1. 32.

26. The contrasts of day and night are those of activity and repose.

30. Eludes thy heart's care.

32. Then = than. Romans viii, 35 . 
Yet still thou goest on,

And now with darknesse closest wearie eyes,

Saying to man, It doth suffice.

Henceforth repose. Your work is done. 20

Thus in thy Ebony box

Thou dost inclose us, till the day

Put our amendment in our way,

And give new wheels to our disorder'd clocks.

I muse which shows more love, 25 The day or night: that is the gale, this th' harbour;

That is the walk, and this the arbour;

Or that the garden, this the grove.

My God, thou art all love.

Not one poore minute 'scapes thy breast

But brings a favour from above.

And in this love, more then in bed, I rest. 
INTRODUCTORY :

Antiphon is the chant or singing of a choir in church, in which strain answers strain. It is described in Christmas, II, 169, 1. 32. Another poem with this title is given, II, 107.

Date:

Not found in W.

Metre:

Unique.

SubJect :

A call for universal praise, from all above and all below. Psalm cxlviii.

Notes:

2. Cf. Jordan, II, 89, 1. 15, and The EuIxer, II, $99,1.1$. 


\section{ANTIPHON}

Cho. LET all the world in ev'ry corner sing, My God and King.

Vers. The heav'ns are not too high, His praise may thither flie.

The earth is not too low,

His praises there may grow.

Cho. Let all the world in ev'ry corner sing, My God and King.

Vers. The church with psalms must shout. No doore can keep them out. 10 But above all, the heart Must bear the longest part.

Cho. Let all the world in ev'ry corner sing, My God and King. 



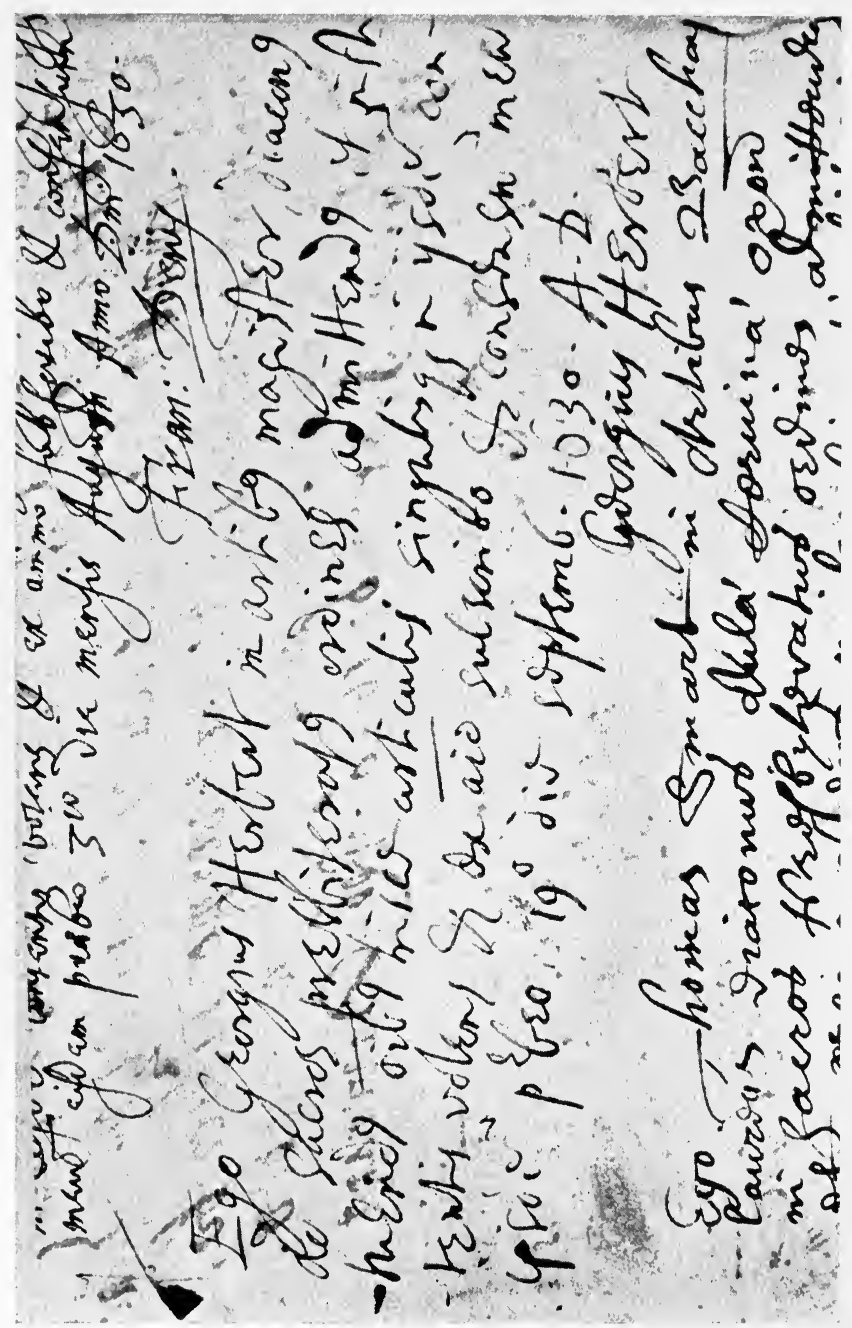



VIII

BEMERTON STUDY 



\section{PREFACE}

M ANY persons find the reflective poetry of 1 Herbert the most agreeable portion of THE Temple. The more personal poems call for larger historical and artistic imagination than most of ${ }^{\circ}$ us care to supply. To reconstruct their reality we must project ourselves into conditions of mind which belong to a bygone age; and few are willing, or even able, to detach themselves from their own time and feel the humanity in types of emotion which look fictitious because unfamiliar. Or if we take the very probable view that in these poems, as in Shakespeare's or Sidney's Sonnets, art is as much concerned as emotion, the chance that Herbert's eager songs will be understood becomes more slender still. For art is little known or honored among us. It interests but few to see a feeling taking its rise in some experience of a poet, then purged of whatever checks its coherence, and gradually furnished with all that can lend it fulness and precision, until it finally comes forth palpitating with fresh and irresponsible life, and exhibits with a completeness not otherwise possible an isolated section of the complex soul of man. Indeed, busy and matter-of-fact folk are disposed to suspect falsehood in anything which bears the 
marks of art, and to count only those emotions genuine which are poured out with the spontaneous disorderliness of nature. Where such instinctive presuppositions exist, the subtle adjustments and intricate accords by means of which Herbert idealizes passions which to-day are but slightly felt will to a considerable extent remove his personal poems from sympathy. Work which charms the lover of exquisite art, and beautiful records of earlier habits of mind which fascinate the imaginative student of spiritual history, will be easily discarded as artificial and full of conceits.

But even then the reflective poetry of Herbert remains. Art is not usually felt to be a disturber of meditation, but rather to be required in utterances of profound thought. Herbert's intellectual verse has accordingly been prized by many who have regarded his emotional with something like contempt. I do not myself think the two kinds can be fully parted. Herbert puts passion into everything, and everything he rationalizes. Yet $I$ have thought I might render him more accessible to all tastes if here among the Bemerton poems, as previously among those of the Cambridge years, I place in a special Group those which are least marked by the personal note. Here stand the compact pieces of wisdom which were shaped in the Wiltshire study. Some of them may have been brought over half-finished from Cambridge, Dauntsey, or Baynton. But in Bemerton they received their 
final form, and they appear only in the manuscript of Herbert's later years.

In this more abstract and contemplative species of verse Herbert is able to exhibit with fullest advantage one of his chief literary merits, I mean his power to charge a few common words with more meaning than they easily carry. The phrase strains; the thought obtrudes beyond the words. By audacity of dietion Herbert forces his reader his energetic reader - to approach at some strange angle new aspects of old truths. We all know the aphoristic force of the Elizabethan and Jacobean poets. They were no mere epigrammatists, like the Queen Anne's men. They cared nothing for propriety, and kept their thoughts on things rather than on words. But nobody has ever been able to/ fashion a phrase with greater certainty that it will| stick in the mind which it once enters. In this penetrative power Herbert stands among the foremost of his age. Few poets are more quotable. He abounds in those "jewels five words long which on the stretched forefinger of all time sparkle forever." Yet his sententious power is not satisfied with creating scattered phrases; these are but the material out of which a pathetic, gay, or sagacious whole is firmly fashioned. The general intellectual tone appropriate to each poem is to Herbert's mind a matter of much consequence, and the phrasing which would enter fitly into one is not allowed to disturb the poise of another. 
Let any reader compare Peace and Dotage, Constancie and The BAg, or either of these with VANitie or Vertue, and he will see how harmoniously selective is Herbert's craftsmanship, how free he is from anything like a single fixed style. All this is less felt because without special training on the reader's part Herbert is difficult to follow. He moves at great speed through strange and tangled regions. He loves "by indirection to find direction out." He does not concern himself with his reader, but with getting his own mind completely delivered.

I have set at the head of this Group Herbert's profoundest philosophic study, Providence. The first impression it will give is that it is queer. Certain lines will seem positively comic. I do not think this fact would have disturbed Herbert, or have brought him to admit the need of change, any more than similar facts in the poetry of Wordsworth, Browning, and Emerson ever worried those explorers of the human soul. Such poets write for themselves, and merely allow other men to listen while they think. Providence is a masterly survey of a closely ordered universe which culminates in man. While lacking modern scientific equipment, trusting too to Aristotelic methods more than would to-day be generally approved, and consequently often mistaking small things for great, Herbert shows a keenness of observation, an ability to group together similar but outwardly 
unlike facts, and a prevision even of modern evolutional points of view, which prove him to have been a man of real grasp in subjects lying outside his special religious themes. The wording is strong throughout, in parts rising to an easy majesty not reached by him elsewhere.

After Providence I place discussions of several features of the Church and its partially detached members, which lead to consideration of the differences between the Biblical Church and our own. Constancie and The Foil show how unshakable a man may become through righteousness; and then his complex and vacillating nature is shown in MaN's Medley, Giddinesse, VaNitie, Dotage, Businesse, Sinnes Round, and The Water-Course. The pessimistic view of man's condition is a favorite with Herbert both on religious and poetic grounds. It shows the need of Atonement, and lends itself to decidedly picturesque treatment. The Pulley and Marie Magdalene point out our way of delivery from restlessness. The Passion of our Lord is set forth in several poems which from style I should suppose to be written early, but which are not included in the Williams Manuscript. At the end of the Group I have placed half-a-dozen trifles in which the fancy of Herbert plays sweetly with its own ingenuities. 

BEMERTON STUDY 


\section{INTRODUCTORY :}

These lines, though not originally included in THE Temple, may well find a place here. They were first printed in Walton's Life: "He then proceeded to rebuild the greatest part of the Parsonage-house, which he did also very compleatly, and at his own charge; and having done this good work, he caus'd these Verses to be writ upon or ingraven in, the Mantle of the Chimney in his Hall." If this inscription ever existed at Bemerton, it long ago disappeared. In recent years it has again been inscribed on the side of the Parsonage facing the Church. Thomas Fuller gives a variant of it in his Holy and Profane State, 1642: “A clergyman who built his house from the ground wrote on it this counsel to his successor :

"If thou dost find

An house built to thy mind,

Without thy cost,

Serve thou the more

God and the poor;

My labour is not lost." 


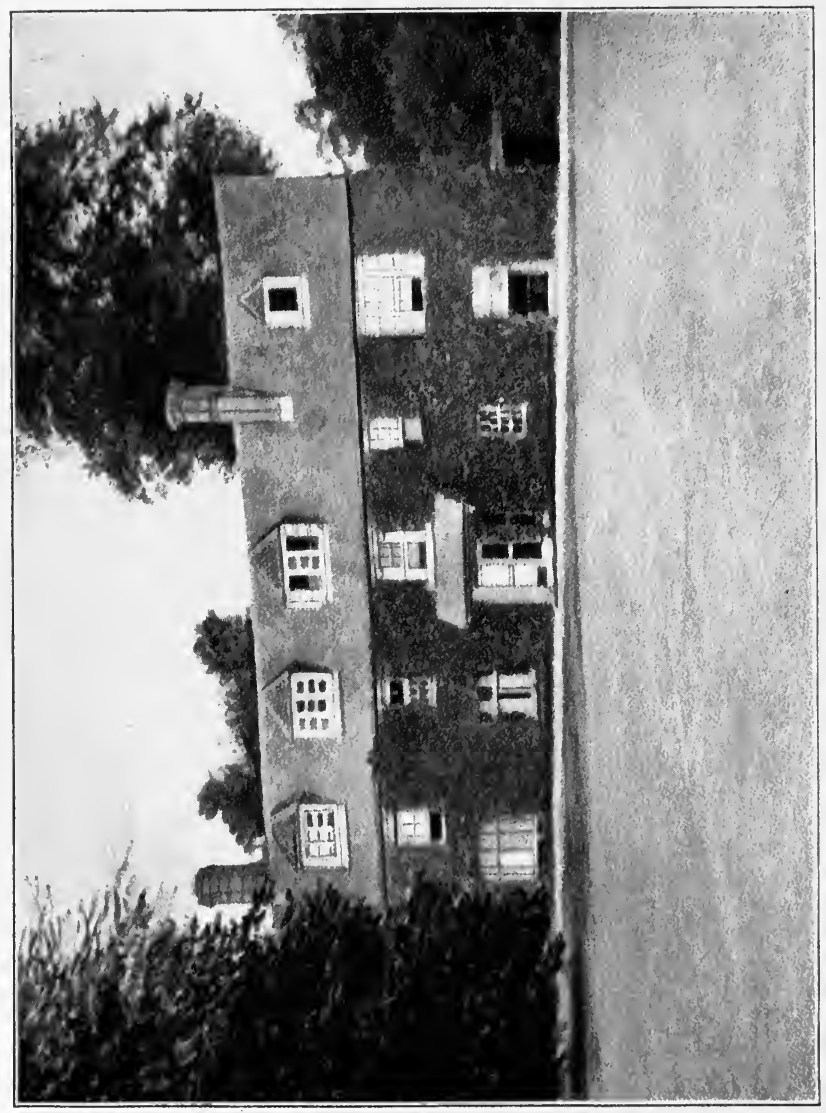





\section{TO MY SUCCESSOR}

If thou chance for to find

A new House to thy mind, And built without thy Cost, Be good to the Poor, As God gives thee store, And then my Labour's not lost. 


\section{PROVIDENCE}

Date:

Not found in W. This is the most considerable poem of the Bemerton years, in style far removed from The Church-Porch. Possibly it was begun at Cambridge, where MAN was written, but, being reserved for correction and addition, was on this account not included in W. It certainly was finished after Herbert's poetic powers had becomefully formed, and was intended, as its closing stanzas indicate, as a kind of climax and epitome of all his thought. Seldom elsewhere does he treat facts in so objective a fashion. Providence was translated into Latin in 1678 by William Dillingham.

Metre:

Unique in stanza form. But alternate rhyming pentameters are also used by Herbert in A WrEATH, II, 319, Love Unknown, III, 179, and Grief, III, 323. This stanza, the heroic quatrain, first used by Surrey, had been consecrated to philosophical reflection by Sir John Davies in his Nosce Teipsum. It was also used by Sylvester in his Urania, by Southwell in his Vale of Tears, and by Donne in several of his Epistles (among them one to Herbert's mother); subsequently by Beaumont in his Psyche, by Davenant in Gondibert, by Dryden in his Oliver Cromwell and Annus Mirabilis, and by Gray in his Elegy. 


\section{SUBJECT:}

"O Lord, how manifold are thy works! in wisdom hast thou made them all:" Psalm civ, 24. Throughout this poem Herbert has in mind the 104th Psalm, which in King James' Version is entitled, “An exhortation to bless the Lord for his mighty power and wonderful providence." But the Psalm merely sets forth the many marvels of the world; while the poem is a description of a world so ordered by evolutionary plan that the higher grades continually grow out of the lower and bring the significanoe of these to light. The conception of an organized universe with man as its crown (cf. MAN, II, 215) was first announced by Aristotle. Herbert may have derived his thought from some such passage as Metaph. XI, 10: "Whatever exists - fish, bird, or plant-has its special place in the scheme of things. There is nothing isolated and unrelated. All have reference to a common unity. While each part has its separate sphere, all also unite and contribute to the good of the whole." The poem has four parts: 1. An Introduction (1. 1-28) on man's supreme and priestly character; after which comes the Psalm itself in two divisions; 2, the first (1. 29-92), celebrating the fulness of God's house; and 3, the second (1. 93-140), pointing out God's curious art in marshalling his goods. 4. A conclusion follows (1. 141-152), announcing the obligation and inadequacy of praise. 
Notes:

1. Wisdom viii, 1. "Attingit a fine usque ad finem fortiter et disponit omnia suaviter." Wisdom reacheth from one end to another mightily; and sweetly doth she order all things.

4. Do thee right (one of Herbert's few puns) = do thee justice.

8. Donne had already written (Satire, 1. 6): "Here is Nature's Secretary, the philosopher;" and Walton in his Life of Herbert calls Lord Bacon "the great Secretary of Nature." When Sylvester in Urania is urging the poets to write on sacred instead of secular themes, he says that then " all would admire your rymes and do you honour As Secretaries of the Heav'nly Court,"' 1. 185.

9. Dittie, - seek to give words to their songs, as in The Sacrifice, II, 137, 1. 142, and The ForeRUNNERS, III, 317,1.11. The thought is repeated in Miserie, II, 255, 1. 55-60.

12. Psalm cxlv, 10.

13. On the publication of Bacon's Instauratio Magna Herbert addressed him in a Latin poem as Mundique et animarum Sacerdos unicus. 


\section{PROVIDENCE}

O SACRED Providence, who from end to end Strongly and sweetly movest! Shall I write, And not of thee through whom my fingers bend To hold my quill ? Shall they not do thee right?

Of all the creatures both in sea and land 5

Onely to Man thou hast made known thy wayes, And put the penne alone into his hand, And made him Secretarie of thy praise.

Beasts fain would sing; birds dittie to their notes; Trees would be tuning on their native lute 10 To thy renown; but all their hands and throats Are brought to Man, while they are lame and mute.

Man is the world's high Priest. He doth present The sacrifice for all; while they below

Unto the service mutter an assent,

Such as springs use that fall and windes that blow. 
21-24. A tongue exists in you, beasts, that you may eat, in me that I may praise; as your fingers, $O$ trees, can only offer fruit, while mine must write.

27. Rent $=$ recompense for use, not merely that derived from lands and houses as with us (cf. ConTent, II, $355,1.28)$, but here from reason and speech.

31. Repeated from 1. 2.

32. So The Church Militant, III, 359, 1. 8.

33-35. In Herbert's mind there is probably some correspondence between the pair of terms of this stanza, command and permission, and the pair of the previous one, power and love. But if so, it is far from clear what the nature of the correspondence is. It is not easy to see how loving permission should operate negatively as a curb, in contrast to the stimulating influence of command. In none of the four poems where power and love are coupled (Prayer, II, 185, 1. 20; The Temper, II, 317, 1. 27; The Method, III, 197, 1. 7; The Church Minitant, III, 359, 1. 10) is love represented as either permissive or restrictive. Perhaps this stanza may be explained thus: Action springs either from a sense of duty (divine command) or from natural instincts (permitted by God), which check that sluggishness and waste through indolence which are seldom absent from Herbert's thought of sin. (Cf. The Church-Ponch, II, 19, 1. 38-96, and 55, 1. 337-342; EMpLotMent, II, 103.) 
He that to praise and laud thee doth refrain Doth not refrain unto himself alone, But robs a thousand who would praise thee fain, And doth commit a world of sinne in one. 20

The beasts say, Eat me; but if beasts must teach, The tongue is yours to eat, but mine to praise. The trees say, Pull me; but the hand you stretch Is mine to write, as it is yours to raise.

Wherefore, most sacred Spirit, I here present 25

For me and all my fellows praise to thee. And just it is that I should pay the rent,

Because the benefit accrues to me.

We all acknowledge both thy power and love

To be exact, transcendent, and divine;

Who dost so strongly and so sweetly move,

While all things have their will, yet none but thine.

For either thy command or thy permission

Lay hands on all. They are thy right and left.

The first puts on with speed and expedition, 35

The other curbs sinne's stealing pace and theft. 
40. The mention of tuning and tempering in the preceding lines suggests to Herbert how deeply we should be affected if all divine concords could be rendered audible, as in the supposed music of the spheres. (Artillerie, II, 361, 1. 9.)

41-44. Cf. The Church Militant, III, 359, 1. 1-4.

42. Even=balanced, constant. An equally unusual use of uneven appears in FAITH, II, 235, 1. 32.

45. Psalm lxv, 7.

48. Jeremiah v, 22; Job xxxviii, 11.

49. Psalm civ, 27; Man, II, 219, l. 29.

51. The net of the fish is its wide mouth.

53. Nothing comes into the world before its fit food is provided.

56. Their, i. e. the creatures of the preceding line. 
Nothing escapes them both. All must appeare, And be dispos'd, and dress'd, and tun'd by thee, Who sweetly temper'st all. If we could heare Thy skill and art, what musick would it be! 40

Thou art in small things great, not small in any, Thy even praise can neither rise nor fall.

Thou art in all things one, in each thing many,

For thou art infinite in one and all.

Tempests are calm to thee. They know thy hand, And hold it fast, as children do their father's, Which crie and follow. Thou hast made poore sand

Check the proud sea, ev'n when it swells and gathers.

Thy cupboard serves the world. The meat is set Where all may reach. No beast but knows his feed.

Birds teach us hawking; fishes have their net; The great prey on the lesse, they on some weed.

Nothing ingendred doth prevent his meat: Flies have their table spread, ere they appeare; Some creatures have in winter what to eat, 55 Others do sleep, and envie not their cheer. 
58. Twist=cord. So The Pearl, II, 383, 1. 38.

61-72. In these three stanzas Herbert traces the economy of the universe, and shows how in each created thing there is a provision for maintaining its type. The old bird helps the young one, and so makes him strong enough to help himself. Nowhere does nature allow real loss, but through some circuitous process what has been spent is eventually restored. Bees draw food from flowers, but without harm to flower, bee, or man. Flowers are consumed by cattle, yet from cattle obtain their needed nutriment. Such nutriment feeds trees, which contribute their leaves to make soil for other trees. Out of the soil streams run into the sea, and from it, by way of the clouds, are themselves renewed. Clouds, produced by the sun's heat, become cooled and descend to form fresh springs. And springs can boil up in obedience to inner heat only when they at the same time send off from their cool upper surface that vapor from which they are ultimately resupplied. 
How finely dost thou times and seasons spin, And make a twist checker'd with night and day! Which as it lengthens windes, and windes us in, As bouls go on, but turning all the way. $\quad 60$

Each creature hath a wisdome for his good.

The pigeons feed their tender off-spring, crying, When they are callow; but withdraw their food When they are fledge, that need may teach them flying.

Bees work for man; and yet they never bruise

Their master's flower, but leave it, having done, As fair as ever and as fit to use;

So both the flower doth stay, and hony run.

Sheep eat the grasse and dung the ground for more.

Trees, after bearing, drop their leaves for soil, Springs vent their streams, and by expense get store.

Clouds cool by heat, and baths by cooling boil. 
75-76. That=for expression. Herbert, always longing for larger powers of expression (cf. PraIse, II, 95, Dulnesse, III, 207, and The Forerunners, III, 317), wonders if an herb may not one day be discovered which will quicken speech. The subtle influence of certain herbs over mental conditions was at that time attracting attention. Tobacco and tea had just been introduced. Macbeth already knows "the insane root that takes the reason captive;" and Othello "the poppy and mandragora and all the drowsy syrops of the world."

77-80. Herbert has great interest in the stars, and ever inclines to a belief in astrology. Such passages as The Pearl, II, 381, 1. 5, The Foil, III, 123, and VANITIE, III, 133, 1. 7, are frequent; and the three strange poems which are wholly dedicated to the stars - Artillerie, II, 361, The Starre, II, 365, and The Storm, III, 263 - suggest, whatever else, an easy access of celestial influence. The thought of this verse is compressed. A star, like the rose, is beautiful. Perhaps its virtues will eventually be directed, like those of the rose, to our healing. Undoubtedly there is in it abundant power for weal or woe, did we but know how to use it. Astrology is true, but the astrologist cannot find it: Jacula Prudentum. On the medicinal powers of the flower, see The Rose, II, 391, 1. 18.

83-84. Repeated in Avarice, III, 113, 1. 14. 
Who hath the vertue to expresse the rare And curious vertues both of herbs and stones? Is there an herb for that? O that thy care 75 Would show a root that gives expressions!

And if an herb hath power, what have the starres? A rose, besides his beautie, is a cure.

Doubtlesse our plagues and plentie, peace and warres

Are there much surer then our art is sure. 80

Thou hast hid metals. Man may take them thence, But at his perill. When he digs the place, He makes a grave; as if the thing had sense, And threatned man that he should fill the space. 
86. No creature is allowed through want of knowledge to be destroyed by poison or to miss the antidote it needs. With this and with 1.105 compare Herbert's Oration on the Return of Charles from Spain: Unamquamque regionem suam sibi sufficere, neque externis indigere auxiliis neque antidotis.

88. The fear $=$ the dreaded object.

96. South, where cool surfaces are welcome; North, where protection is needed against cold.

97. Good-cheap is dear: Jacula Prudentum.

100. The harsh but stimulating cold is as needful for man as the easily gathered fruits. 
Ev'n poysons praise thee. Should a thing be lost ? Should creatures want for want of heed their due?

Since where are poysons, antidots are most; $\quad 87$ The help stands close and keeps the fear in view.

The sea, which seems to stop the traveller,

Is by a ship the speedier passage made. 90 The windes, who think they rule the mariner, Are rul'd by him and taught to serve his trade.

And as thy house is full, so $I$ adore

Thy curious art in marshalling thy goods.

The hills with health abound; the vales with store;

The South with marble; North with furres and woods.

Hard things are glorious; easie things good cheap. The common all men have; that which is rare Men therefore seek to have and care to keep.

The healthy frosts with summer-fruits compare. 
102. Shade $=$ the shelter formed by overhanging branches. 103-4. Tall and low are contrasted, the one meaning far from the ground, the other near to it. Low is used in the same sense in The Banquet, III, 57, 1. 40.

104. Hawks are mentioned in 1. 51, in The SACRIFICE, II, 131, 1. 91, and alluded to in The Pearl, II, 383, 1. 32. Other sports named by Herbert are bowling, fencing, archery, and cards; but he nowhere mentions ball-play, hunting, or dancing.

112. In desire $=$ as much as he needs. Cf. 1. 105 .

114. Lay gather'd, i. e. into lakes and the ocean. Broach $=$ tap, so as to make streams run, as in Divinitie, III, 99, 1. 9.

118. Hony drops=drops which make honey. 
Light without winde is glasse; warm without weight

Is wooll and furres; cool without closenesse, shade;

Speed without pains, a horse; tall without height,

A servile hawk; low without losse, a spade.

All countreys have enough to serve their need. 105

If they seek fine things, thou dost make them run For their offence; and then dost turn their speed

To be commerce and trade from sunne to sunne.

Nothing wears clothes but Man; nothing doth need

But he to wear them. Nothing useth fire 110 But Man alone, to show his heav'nly breed. And onely he hath fuell in desire.

When th' earth was dry, thou mad'st a sea of wet.

When that lay gather'd, thou didst broach the mountains.

When yet some places could no moisture get, 115

The windes grew gard'ners, and the clouds good fountains.

Rain, do not hurt my flowers, but gently spend Your hony drops! Presse not to smell them here.

When they are ripe, their odour will ascend 119 And at your lodging with their thanks appeare. 
121-124. Good qualities are sometimes divided, as in this stanza; sometimes united, as in the next. 126. Indian $n u t=$ cocoanut.

127. $K a n=$ drinking-cup.

129-132. Besides the medical observations of this verse, others occur in $1.78,87,100$. For Herbert's general interest in medicine, see his Country Parson, XXIII; and for the similar interest of his brother, Lord Herbert, see Autobiography, Lee's ed., p. 52-59.

133. Leap not: "Natura non facit saltum." There is no gap in nature or unfilled gradation, all parts are interlinked. This and the following line well sum up the fundamental doctrine of the poem, viz. that creation is ordered, compact, full (1. 93), evolutional, as Aristotle had suggested. So MAN, II, 217, 1. 15; EMployment, II, 349, 1. 21; LoNGING, III, 285, 1. 53.

135. Marry = form a connecting link between.

136. Out of the earth come coal and diamonds, which once were plants. Perhaps there is also allusion to the popular fancy that minerals grow. 
How harsh are thorns to pears! And yet they make

A better hedge, and need less reparation.

How smooth are silks compared with a stake, Or with a stone! Yet make no good foundation.

Sometimes thou dost divide thy gifts to man, 125 Sometimes unite. The Indian nut alone Is clothing, meat and trencher, drink and kan, Boat, cable, sail and needle, all in one.

Most herbs that grow in brooks are hot and dry. Cold fruits' warm kernells help against the winde.

The lemmon's juice and rinde cure mutually.

The whey of milk doth loose, the milk doth binde.

Thy creatures leap not, but expresse a feast Where all the guests sit close, and nothing wants. Frogs marry fish and flesh; bats, bird and beast; Sponges, non-sense and sense; mines, th' earth and plants. 
138. Changest thy mode of action. Variation is as important a principle in nature as uniformity.

140. Donne, Progress of the Soul, First Song, 385, says of the elephant:

"Nature hath given him no knees to bend, Himself he up-props, on himself relies, Still sleeping stood."

Sir Thomas Browne in his Vulgar Errors, Bk. III, ch. i, examines at length the popular belief that the elephant has no joints in his legs and consequently "sleepeth against a tree."

141. Psalm cvi, 2.

144. Owes, for owns. But Herbert also uses own, THE Eurxer, II, 101, I. 23.

145-152. These last two stanzas are alternative renderings of a single theme, paralleling each other clause by clause. Probably at his death Herbert had not decided which of the two to keep as his ending; but though on the whole preferring 1. 145148, he still wished to preserve in his manuscript 1. 149-152 for future estimate. Ferrar, not noticing the duplicate character of the stanzas, printed them both.

148. Twice, i. e. for me and all my fellows, 1. 26. This poem, then, would seem to have been written later than a large body of his verse.

152. One waye more, i. e. as the world's high Priest, 1. 13. 
To show thou art not bound, as if thy lot

Were worse then ours, sometimes thou shiftest hands.

Most things move th' under-jaw; the Crocodile not.

Most things sleep lying; th' Elephant leans or stands.

But who hath praise enough? Nay who hath any? None can expresse thy works but he that knows them.

And none can know thy works, which are so many And so complete, but onely he that owes them.

All things that are, though they have sev'rall wayes,

Yet in their being joyn with one advise

To honour thee. And so I give thee praise

In all my other hymnes, but in this twice.

[Each thing that is, although in use and name

It go for one, hath many wayes in store 150

To honour thee. And.so each hymne thy fame

Extolleth many wayes, yet this one more.] 
Date:

Not found in W.

Metre:

Used also in Church-Musick, II, 199, and CoNTENT, II, 353.

SUBJECT:

We may easily be over-curious in theology, where in reality the plain truths are the important ones. Cf. VANITIE, III, 133. This sort of distinction between needless truth and practical truth nowhere appears in The Country Parson, but on the contrary, Ch. V says: The Countrey Parson hath compiled a book and body of Divinity, which is the storehouse of his Sermons and which he preacheth all his Life. Notes:

1. This stanza well illustrates the kind of intellectual humor of which Herbert is fond (I, 65). Men devise celestial globes to mark the courses of the stars, and books of divinity to mark the ways of God, - fantastic, mechanical representations, harder to comprehend than the realities which they interpret. On the nature of these spheres, see the note on Prayer, II, 183, 1.9.

8. Faith is maimed by the incisiveness of reason. 


\section{DIVINITIE}

As men, for fear the starres should sleep and nod And trip at night, have spheres suppli'd, As if a starre were duller then a clod, Which knows his way without a guide;

Just so the other heav'n they also serve, 5

Divinitie's transcendent skie, Which with the edge of wit they cut and carve. Reason triumphs, and faith lies by. 
9. To broach is to make an opening in a cask for liquid to run out, as in The Agonie, III, 153, 1. 15. The blood of Christ's wounded side is mentioned in seven other passages. See The BAG, III, 157.

11. Fine $=$ had it been a fashionably cut garment. "The metaphor was suggested, no doubt, by the quaintly carved, cut, slashed, and paned dresses of Herbert's time:" A. B. Grosart. - Jag=to cut into points. We still use it in the adjective jagged.

15. Which onely save = are the only ones which save.

24. And is not obscure.

25. A term of the Ptolemaic astronomy. Do not keep making finer and finer hypotheses to explain the subtleties of heavenly facts.

26. The spheres of 1. 2. Save yourself such mental strain, 1. 7.

27. The staffe may here be the surveyor's staff of THE Agonie, III, 153, 1. 3. 
Could not that wisdome which first broacht the wine

Have thicken'd it with definitions?

And jagg'd his seamlesse coat, had that been fine, With curious questions and divisions?

But all the doctrine which he taught and gave Was cleare as heav'n, from whence it came. At least those beams of truth which onely save 15 Surpasse in brightnesse any flame.

Love God and love your neighbour. Watch and pray.

Do as ye would be done unto.

O dark instructions! Ev'n as dark as day!

Who can these Gordian knots undo?

But he doth bid us take his bloud for wine.

Bid what he please! Yet I am sure

To take and taste what he doth there designe

Is all that saves, and not obscure.

Then burn thy Epicycles, foolish man.

Break all thy spheres and save thy head.

Faith needs no staffe of flesh, but stoutly can

To heav'n alone both go and leade. 
Date:

Not found in W.

Metre:

Unique.

SubJect:

The English Church, a beautiful mean between the tawdry Romish and barren Presbyterian. So Epigrammata Apologetica, XXVIII. Cf. Donne, Satire III, 43-62.

Notes:

5. It might be thought that Herbert is here approving the ecclesiastical practice of dating by the Church Year. But all his letters, even those from Bemerton, are dated by the secular month and day.

10. Outlandish = foreign and strange, as in FArTH, II, 233, 1. 9, and in the title of Jacula Prudentum, "Outlandish Proverbs."

11. Painted = artificial, unreal, as in JoRDAN, II, 87, 1. 5 . 


\section{THE BRITISH CHURCH}

I Joy, deare Mother, when I view Thy perfect lineaments, and hue Both sweet and bright. Beautie in thee takes up her place, And dates her letters from thy face

When she doth write.

A fine aspect in fit array,

Neither too mean, nor yet too gay,

Shows who is best.

Outlandish looks may not compare, For all they either painted are,

Or else undrest. 
14. The Church of Rome, throned on her seven hills, a world-church, was more attractive to ambitious men than the local church of England.

16. Rome has tolerated a sentimental artificiality in so many details of her worship that her whole system of religion has come to seem artificial, her face to be daubed with paint, 1. 11.

26. The mean=the middle path, Aristotle's $\mu \epsilon \sigma o ́ \tau \eta s$. Cf. The Country Parson, XIII : All this he doth not as out of necessity, or as putting a holiness in the things, but as desiring to keep the middle way between superstition and slovenlinesse.

29. To make thee as secure as a castle with two moats, protected against the twofold dangers of ostentation and disorder. The religious disturbances of his time Herbert discusses also in the next poem, in The Priesthood, II, 375,1. 33, and allegorically in Humilitie, II, 239. 
She on the hills which wantonly

Allureth all, in hope to be

$$
\text { By her preferr'd, }
$$

Hath kiss'd so long her painted shrines That ev'n her face by kissing shines, For her reward.

She in the valley is so shie

Of dressing that her hair doth lie

About her eares;

While she avoids her neighbour's pride, She wholly goes on th' other side, And nothing wears.

But dearest Mother, (what those misse,) 25 The mean, thy praise and glorie is And long may be.

Blessed be God, whose love it was To double-moat thee with his grace, And none but thee. 


\section{CHURCH-RENTS AND SCHISMES}

Date:

Not found in W.

Metre:

Unique.

SubJect :

Divisions within the church (schismes) are more serious than attacks from without (rents).

Notes:

1. Perhaps he is led to figure the Church, Christ's body, as a rose on account of the Rose of Sharon, (Song of Solomon ii, 1). But quite as likely the rose is employed merely as the object which is fairest; cf. The Rose, II, 391, 1. 17.-Chair=throne, stately place. So, too, 1. 10, and The Temper, II, 313, 1.9.

2. Triumph, accented on the last syllable as in DrvinITIE, III, 97, 1. 8.

5. So Peace, II, 377, 1. 17.

6. Perhaps bottome here means not the under part, but the stem. Cf. The Discharge, III, 191, 1. 45. 


\section{CHURCH-RENTS AND SCHISMES}

Brave rose, (alas!) where art thou? In the chair

Where thou didst lately so triumph and shine

A worm doth sit, whose many feet and hair Are the more foul the more thou wert divine. This, this hath done it, this did bite the root 5 And bottome of the leaves; which when the winde

Did once perceive, it blew them under foot, Where rude unhallow'd steps do crush and grinde

Their beauteous glories. Onely shreds of thee, And those all bitten, in thy chair I see. 
14. Martyrdoms. Foxe's Book of Martyrs was published thirty years before Herbert was born.

17. Cf. The World, II, 227, 1. 13.

22. North-winde; cf. 1. 6. The influence of Scotch Presbyterianism was continually increasing in England. Possibly we may find here an allusion to Melville's Anti-Tami-Cami-Categoria, which in early life Herbert had answered (I, 25).

23. Them=your sev'ral parts (1. 21).

27. When only this little spot of earth is awake to the Gospel, shall we here be disunited?

29. The thought of these two lines is expanded in GrIEF, III, 323, 1. 1-10. 
Why doth my Mother blush? Is she the rose And shows it so? Indeed Christ's precious bloud

Gave you a colour once; which when your foes

Thought to let out, the bleeding did you good, And made you look much fresher then before. 15

But when debates and fretting jealousies

Did worm and work within you more and more,

Your colour faded, and calamities

Turned your ruddie into pale and bleak.

Your health and beautie both began to break. 20

Then did your sev'rall parts unloose and start.

Which when your neighbours saw, like a northwinde

They rushed in and cast them in the dirt,

Where Pagans tread. O Mother deare and kinde,

Where shall I get me eyes enough to weep, 25

As many eyes as starres? Since it is night, And much of Asia and Europe fast asleep, And ev'n all Africk. Would at least I might With these two poore ones lick up all the dew Which falls by night, and poure it out for you! 


\section{INTRODUCTORY :}

Vaughan has enlarged this in his poem, The Jews.

There is a curious passage on the Jews in The Country Parson, XXXIV.

\section{DATE:}

Not found in W.

Metre:

Unique, but differs only in rhyming system from Justice, III, 253.

SubJECT:

Christianity grafted upon Judaism has absorbed the vitality of the Jews, and should now repay. Cf. Romans xi, 17-21.

Notes:

2. $C$ yens $=$ scions, grafts.

3. By Apostolic succession. Cf. Whitsunday, II, 157, 1. 17.

6. By keeping the letter, they lose it.

8. Revelation viii, 6.

12. Job xiv, 9. 


\section{THE JEWS}

Poore nation, whose sweet sap and juice Our cyens have purloin'd, and left you drie;

Whose streams we got by the Apostles' sluce And use in baptisme, while ye pine and die; Who, by not keeping once, became a debter, 5 And now by keeping lose the letter;

Oh that my prayers! mine, alas! Oh that some Angel might a trumpet sound, At which the Church falling upon her face Should crie so loud untill the trump were drown'd, And by that crie of her deare Lord obtain

That your sweet sap might come again! 
Date:

Not found in W.

Metre:

Unique.

SUBJECT:

The preferring of Barabbas (popularity with the multitude), or of Judas (gold), to Christ has not ceased in our day.

Notes:

6. That choice = the choosing of Barabbas. Thy storie $=$ the description of you. Storie is used five times by Herbert in this sense, and also rhyming with glorie: The Church-Porch, II, 21, 1.52, and 25, 1. 94, Complaining, III, 267, 1. 7, and A DiaLOGUe-ANtheme, III, 343, 1. 3. Cf., too, Crashaw's Wishes to his Supposed Mistress: "Be you my fictions, but her story."

10. John viii, 44.

12. Her where we should use its, which was hardly established in Herbert's time.

18. So Vaughan in his Rules and Lessons, p. 45: "Who sells Religion is a Judas-Jew." In The Country Parson, II, Herbert writes: They who for the hope of promotion neglect any necessary admonition or reproofe, sell (with Judas) their Lord and Master.

19. Prevent=anticipate. 1 Corinthians xi, 31.

20. That light=conscience, Proverbs xx, 27; John i, 9. 


\section{SELF-CONDEMNATION}

Tнол who condemnest Jewish hate For choosing Barabbas, a murderer,

Before the Lord of glorie,

Look back upon thine own estate,

Call home thine eye (that busie wanderer),

That choice may be thy storie.

He that doth love, and love amisse, This world's delights before true Christian joy, Hath made a Jewish choice.

The world an ancient murderer is; 10

Thousands of souls it hath, and doth destroy

-With her enchanting voice.

He that hath made a sorrie wedding Between his soul and gold, and hath preferr'd

False gain before the true,

Hath done what he condemnes in reading; For he hath sold for money his deare Lord, And is a Judas-Jew.

Thus we prevent the last great day, And judge our selves. That light which sin and passion

Did before dimme and choke,

When once those snuffes are ta'ne away, Shines bright and cleare, ev'n unto condemnation, Without excuse or cloke. 
Date:

Not found in W.

Metre:

Of seventeen sonnets, six - like this - are in the Shakespearian form.

SuBJEct:

Money, though created by man, has become his master.

Notes:

1. 1 Timothy vi, 10 .

9. Forcing; cf. The Pearl, II, 381, 1. 6.

10. The face of man=the king's head on the coin.

14. So, too, Providence, III, 87, 1. 82-84. 


\section{AVARICE}

Money, thou bane of blisse and sourse of wo, Whence com'st thou that thou art so fresh and fine?

I know thy parentage is base and low, Man found thee poore and dirtie in a mine. Surely thou didst so little contribute

To this great kingdome which thou now hast got

That he was fain, when thou wert destitute,

To digge thee out of thy dark cave and grot. Then forcing thee by fire, he made thee bright.

Nay, thou hast got the face of man, for we 10 Have with our stamp and seal transferr'd our right; Thou art the man, and man but drosse to thee. Man calleth thee his wealth, who made thee rich, And while he digs out thee, falls in the ditch. 
DAte:

Not found in W.

Metre:

Unique, but differs only in rhyming system from JORDAN, II, 87.

SuBJECT:

Throughout recorded history the field of intercourse between God and man has steadily narrowed. Cf. Whitsunday, II, 157.

Notes:

1-3. Genesis xix, 3; xxxii, 24; xviii, 33; Judges vi, 11.

4. To-day God silently endures human complaints; with Moses $\mathrm{He}$ was so intimate that $\mathrm{He}$ could speak and check them. Exodus xxxii, 14.

5. Exodus xxxii, 10.

7. Judges vi, 11; Exodus iii, 2; 1 Kings xix, 9; Genesis xxiv, 11.

9. Exodus xix, 20.

10. Exodus xxviii, 33-35. Cf. Aaron, III, 11, 1. 3.

12. Luke xvii, 21.

13. Sinne $=$ original sin; Satan may refer to present ill-doing. Cf. Self-Condemnation, III, 111, 1. 20.

15. The portion left by Sin and Satan, who are here figured as independent.

16. Whenas = since thy love - once widespread, but now forced back by sin-keeps itself hidden, awaiting the flames of the judgment day.

18. Closet up itself. Cf. Whitsunday, II, 159, 1. 21. 


\section{DECAY}

SwEET were the dayes when thou didst lodge with Lot,

Struggle with Jacob, sit with Gideon,

Advise with Abraham, when thy power could not

Encounter Moses' strong complaints and mone.

Thy words were then, Let me alone. 5

One might have sought and found thee presently At some fair oak, or bush, or cave, or well. Is my God this way? No, they would reply,

$\mathrm{He}$ is to Sinai gone as we heard tell.

List, ye may heare great Aaron's bell.

But now thou dost thy self immure and close

In some one corner of a feeble heart, Where yet both Sinne and Satan, thy old foes,

Do pinch and straiten thee and use much art

To gain thy thirds and little part.

I see the world grows old, whenas the heat Of thy great love once spread, as in an urn Doth closet up itself and still retreat, Cold sinne still forcing it, till it return, And calling Justice, all things burn. 20 
INTRODUCTORY :

Another poem with this title is given, III, 253. This much resembles DeATH, II, 263.

Date:

Not found in W.

Metre:

Unique.

SubJeCt:

The justice of God, as revealed by Christ, is friendly, not hostile.

Notes:

5. Discolour=take away the living color, make thee ghastly. The word is used again in Affuiction, III, 269, 1. 10.

7. The dishes are the pans of the scales of justice. The beam is the cross-piece from which the dishes hang; the scape, the upright part at right angles with the beam.

10. Tort'ring, thus spelled in ed. 1633, meaning torturing, has often been erroneously printed tottering.

13. 2 Corinthians iii, 14. - Pure $=$ transparent.

19, 21. The emphatic words are me and thee. 


\section{JUSTICE}

O DREADFULl Justice, what a fright and terrour Wast thou of old,

When sinne and errour

Did show and shape thy looks to me, And through their glasse discolour thee! 5 He that did but look up was proud and bold.

The dishes of thy ballance seem'd to gape,

Like two great pits.

The beam and scape

Did like some tort'ring engine show.

Thy hand above did burn and glow,

Danting the stoutest hearts, the proudest wits.

But now that Christ's pure vail presents the sight, I see no fears.

Thy hand is white, 15

Thy scales like buckets, which attend

And interchangeably descend,

Lifting to heaven from this well of tears.

For where before thou still didst call on me,

Now I still touch

And harp on thee.

God's promises have made thee mine.

Why should I justice now decline?

Against me there is none, but for me much. 
INTRODUCTORY:

Several writers of Herbert's time $-N$. Breton, Chapman, J. Earle, Bishop Hall, Sir T. Overbury, and, in modified form, Sir J. Davies - had made elaborate studies of single human traits, much in the manner of Theophrastus in his Characters. This poem, so unlike Herbert's other work, is an experiment in following the current fashion. Vaughan imitates it in his Righteousness. The Standard of Equality, by Philo-Decaeus, was dedicated in 1647 to Sir John Danvers, the stepfather of Herbert, in these words: "Lighting casually on the poems of Mr. George Herbert, lately deceased, (whose pious life and death have converted me to a full belief that there is a St. George,) and therein perusing the description of a constant man, it directed my thoughts unto yourself; having heard that the author in his lifetime had therein designed no other title than your character in that description." These are the words of a flattering dedicator. Few persons could be found less like Herbert's Constant Man than Sir John Danvers. See I, 24.

Date:

Not found in W.

Metre:

Unique.

SubJeCT:

The sturdy righteousness which is not prompted or checked by expediency. Perhaps he has in mind the 101st Psalm, which in The Country Parson, 


\section{CONSTANCIE}

Who is the honest man?

He that doth still and strongly good pursue, To God, his neighbour, and himself most true.

Whom neither force nor fawning can Unpinne or wrench from giving all their due. 5

Whose honestie is not

So loose or easie that a ruffling winde Can blow away, or glittering look it blinde.

Who rides his sure and even trot

While the world now rides by, now lags behinde.

Who, when great trials come,

Nor seeks nor shunnes them; but doth calmly stay

Till he the thing and the example weigh.

All being brought into a summe,

What place or person calls for, he doth pay. $\quad 15$ 
$\mathbf{X}$, he advises should be expressed in a fayre table as being the rule of a family, and hung upon the wall. Notes:

1. Cf. Psalm xv, and Horace's Integer Vitae. A vigorous paraphrase of the latter had just appeared in Campion's The Man of Life Upright. The virtue of Constancie was a favorite one with Herbert; cf. The Church-Porch, II, 27, 1. 115-120.

6. Vaughan has paraphrased this stanza in his Rules and Lessons, stanza ix.

8. Glittering look, a dazzling glance of the great cannot make the honest man shut his eyes to iniquity.

13. The thing and the example=the principle and its special application.

20. Cf. Donne, Letter to Lady Carey, 1. 34. The three words in Herbert's stanza which formerly rhymed are now all pronounced differently.

24. Others do right so long as eyes can see them. He regards only Virtue's all-observing eye.

26-30. I forget all things so I may do them good who want it. So I do my part to them, let them think of me what they will or can. If I should regard such things, it were in another's power to defeat my charity, and evil should be stronger than good: Herbert's letter to his brother Henry, 1630.

31 . When the world's game runs counter to his righteous purposes (cf. Affliction, II, 345, 1. 53), nothing can induce him to distort his movements away from his purpose into conformity with evil. 
Whom none can work or wooe To use in any thing a trick or sleight, For above all things he abhorres deceit.

His words and works and fashion too All of a piece, and all are cleare and straight. 20

Who never melts or thaws At close tentations. When the day is done, His goodnesse sets not, but in dark can runne.

The sunne to others writeth laws, And is their vertue. Vertue is his Sunne.

Who, when he is to treat

With sick folks, women, those whom passions sway,

Allows for that and keeps his constant way.

Whom others' faults do not defeat;

But though men fail him, yet his part doth play.

Whom nothing can procure,

When the wide world runnes bias, from his will To writhe his limbes, and share, not mend the ill.

This is the Mark-man, safe and sure, Who still is right, and prayes to be so still. 
INTRODUCTORY :

A foil is a piece of metal employed as a setting for a jewel, in order to give it richer color. Cf. Tо тнв Queene of Bohemia, III, 425, 1. 16. So Shakespeare, Lover's Complaint, 1. 153:

"Which remain'd the foil

Of this false jewel, and his amorous spoil."

DATE:

Not found in W.

Metre:

Unique.

SubJect:

Grief brings out the nature of sin as heaven does that of virtue.

Notes:

1. If we below could see.

8. Grief. Is this possibly a misprint for $\sin$ ? In 1.6 vertues and sinning are parallel. The sense seems to require that they should be so here. 


\section{THE FOIL}

IF we could see below

The sphere of vertue and each shining grace

As plainly as that above doth show,

This were the better skie, the brighter place.

God hath made starres the foil

To set off vertues, griefs to set off sinning.

Yet in this wretched world we toil

As if grief were not foul, nor vertue winning. 
INTRODUCTORY :

Translated into Latin in 1678 by William Dillingham, with the title GaUdiuM.

Date:

Not found in W.

Metre:

Unique.

SubJect :

"Man has double joys and sorrows, answering to his double nature; but the soul's joys are to be preferred, as lasting into the world beyond:" H. C. Beeching.

Notes:

8. Make their pretence = lay hold upon. See JoRdan, II, 93, 1. 16. 


\section{MAN'S MEDLEY}

Heark, how the birds do sing,

And woods do ring!

All creatures have their joy, and man hath his.

Yet if we rightly measure,

Man's joy and pleasure

Rather hereafter then in present is.

To this life things of sense Make their pretence;

In th' other Angels have a right by birth.

Man ties them both alone,

And makes them one,

With th' one hand touching heav'n, with th' other earth. 
15. A dark passage, the difficulties mainly connecting themselves with the significance of lace, the meaning of after, and the subject of should. The curious lace may represent that beauty (cf. Peace, II, 377, 1. 9; The Pearl, II, 381, 1. 16) which, everywhere fringing physical objects, seems never really to belong to them. Still further along in the spiritual direction, next after this beautiful trimming, rather than after, or in accordance with, his material stuff, - man (he of 1.15) should take his place or get his significance. So interpreted, the passage would be a characteristic bit of Herbert's Platonism. But the sense of after is severely strained. In Employment, II, 347, 1. 12, the stuff or material of our life is said to be with God.

30. Herbert uses the same rhyme in the second stanza, and often elsewhere. Throughout the seventeenth century the word one was pronounced not like our won, but like our own; as we still pronounce it in alone, and sometimes in none and only. See SePulchre, III, 155, 1. 3. 
In soul he mounts and flies,

In flesh he dies.

He wears a stuffe whose thread is coarse and round,

But trimm'd with curious lace,

And should take place

After the trimming, not the stuffe and ground.

Not that he may not here

Taste of the cheer;

But as birds drink and straight lift up their head,

So must he sip and think

Of better drink

He may attain to after he is dead.

But as his joyes are double,

So is his trouble.

He hath two winters, other things but one.

Both frosts and thoughts do nip

And bite his lip,

And he of all things fears two deaths alone. 30

Yet ev'n the greatest griefs

May be reliefs,

Could he but take them right and in their wayes.

Happie is he whose heart

Hath found the art

To turn his double pains to double praise. 


\section{GIDDINESSE}

\section{Date:}

Not found in W.

\section{Metre:}

Used also in Dulnesse, III, 207.

\section{SubJect:}

“Unite my heart to fear thy name:" Psalm Ixxxvi,

11. There is likeness of thought between this poem and Miserie, II, 251, where man's wretchedness is attributed to his instability.

\section{Notes:}

11. Snudge = to lie snug, to sleep. So Vaughan understands it in his Misery, 1. 65:

"The age, the present times, are not To snudge in and embrace a cot." 


\section{GIDDINESSE}

$\mathrm{OH}$, what a thing is man! How farre from power, From setled peace and rest!

$\mathrm{He}$ is some twentie sev'rall men at least

Each sev'rall houre.

One while he counts of heav'n as of his treasure;

But then a thought creeps in

And calls him coward who for fear of sinne

Will lose a pleasure.

Now he will fight it out and to the warres;

Now eat his bread in peace

And snudge in quiet. Now he scorns increase;

Now all day spares. 
12. Spares = saves his money, is sparing, - its usual meaning in Herbert. Spare in its other sense - to part with - occurs in Herbert only rarely. MonTIFICATION, II, 261, 1. 34.

15. It is partly true that a whirlwind blows, for his mind is like a whirlwind.

17. Cf. The Church-Porch, II, 17, 1. 23.

19. In dying the dolphin takes on a variety of colors, which Herbert attributes to its changing feelings. So Byron, Childe Harold, IV, stanza xxix:

"Parting day

Dies like the dolphin, whom each pang imbues With a new colour as it gasps away." 
He builds a house, which quickly down must go, As if a whirlwinde blew And crusht the building; and it's partly true, His minde is so.

$\mathrm{O}$ what a sight were Man if his attires

Did alter with his minde;

And like a Dolphin's skinne, his clothes combin'd With his desires!

Surely if each one saw another's heart, There would be no commerce, No sale or bargain passe. All would disperse, And live apart.

Lord, mend or rather make us. One creation 25 Will not suffice our turn.

Except thou make us dayly, we shall spurn Our own salvation. 
INTRODUCTORY :

Another poem with this title is given, II, 357. DATE :

Not found in $\mathbf{W}$.

Metre:

Unique.

SuBJECT:

Man's zeal and success in pursuing things remote and unimportant. Cf. Divinitie, III, 97.

Notes:

1. For the appropriateness of these words bore and thred see note on Prayer, II, 183, 1. 9.

3. Cf. The Agonie, III, 153, 1. 3.

7. "Aspects = the appearance of the planets in their relation to each other, and therefore in their supposed influence on earthly matters:" A. R. Waller. - Fulley'd is used again in The Glance, III, 331, 1. 20.

14. A similar thought appears in Providence, III, 87, l. 81 . 


\section{VANITIE}

The fleet Astronomer can bore And thred the spheres with his quick-piercing minde.

He views their stations, walks from doore to doore,

Surveys as if he had design'd 4

To make a purchase there. He sees their dances, And knoweth long before Both their full-ey'd aspects and secret glances.

The nimble Diver with his side Cuts through the working waves, that he may fetch

His dearely-earned pearl, which God did hide

On purpose from the ventrous wretch;

That he might save his life, and also hers

Who with excessive pride

Her own destruction and his danger wears. 
15. From any created object the chemist can strip the outward traits, and by analysis lay bare the ultimate elements, studying these in their detachment instead of in those composite forms in which they usually present themselves to our senses.

17. Callow=unfledged. Providence, III, 85, 1. 63.

23. So in The Сhurch-Porch, II, 15, 1. 9, we read of God's lesson written in the soul. Jeremiah xxxi, 33.

26. Romans $x, 6-8$. 
The subtil Chymick can devest

And strip the creature naked, till he finde The callow principles within their nest.

There he imparts to them his minde, Admitted to their bed-chamber, before

They appeare trim and drest

To ordinarie suitours at the doore.

What hath not man sought out and found, But his deare God? Who yet his glorious law Embosomes in us, mellowing the ground 24 With showres and frosts, with love and aw,

So that we need not say, Where's this command? Poore man, thou searchest round To finde out death, but missest life at hand. 
DATE.

Not found in W.

METRE:

Unique, but differs only in rhyming system from The Priesthood, II, 373.

SUBJECT:

Doting man mistakes nothing for something. Notes:

1. Glozing = flatteringly deceptive. So Milton, Paradise Lost, III, 93: "Man will hearken to his glozing lies." - Casks=empty barrels. Dr. Grosart proposes the emendation husks to correspond with rooted miseries in the next stanza.

2. Night-fires=ignes fatui, will-o'-the-wisps.

3. Chases in Arras=hunting-parties in silk, instead of in flesh and bone,-contrasted with the surefooted griefs of 1.9 .

4. Career $=$ full tilt, as in Joseph's CoAT, III, 301, 1. 6.

5. In Vanitie, II, 357, 1. 4, solid work is contrasted with false embroyderies. There is a Spanish proverb: "Nada entre duos platos."

7. Same phrase in Obedience, II, 387, 1. 28.

8. In grain= going through and through.-Ripe and blown $=$ in full flower.

14. In The Country Parson, XV, Herbert speaks of the miserable comparison of the moment of griefs here with the weight of joyes hereafter. 


\section{DOTAGE}

FaLSE glozing pleasures, casks of happinesse,

Foolish night-fires, women's and children's wishes,

Chases in Arras, guilded emptinesse,

Shadows well mounted, dreams in a career, 4

Embroider'd lyes, nothing between two dishes; These are the pleasures here.

True earnest sorrows, rooted miseries,

Anguish in grain, vexations ripe and blown, Sure-footed griefs, solid calamities,

Plain demonstrations, evident and cleare,

Fetching their proofs ev'n from the very bone;

These are the sorrows here.

But oh the folly of distracted men,

Who griefs in earnest, joyes in jest pursue;

Preferring, like brute beasts, a lothsome den 15

Before a court, ev'n that above so cleare,

Where are no sorrows, but delights more true

Then miseries are here! 
Date:

Not found in W.

Metre:

The couplets are like those of AntipHon, II, 107. The triplets are unique. The rhyming vowel at the beginning and near the end is $a$. All the other rhymes are in $e$ or $o$.

SubJect:

After sinning, there is only one business,-energetic repentance. Lines 3-14 (the human side of sin) correspond with lines 17-28 (the divine side). Notes:

1. Idle here and in $1.15=$ indifferent, doing nothing about it, the quality described at length in Miserie, II, 251.

3. Elsewhere waters know their work and seek their end. How is it with the waters of the eye?

8. The man of faults and fears will need tears.

9. Plot: it is their plan or scheme to be never at rest.

14. If you will not put yourself to the slight pain of repentance, it is a pity you have a body in which pungent effects of sin must be recorded. These lines correspond with 1.7 and 8. 


\section{BUSINESSE}

Canst be idle? Canst thou play, Foolish soul, who sinn'd to day?

Rivers run, and springs each one Know their home, and get them gone.

Hast thou tears, or hast thou none?

If, poore soul, thou hast no tears, Would thou hadst no faults or fears!

Who hath these, those ill forbears.

Windes still work; it is their plot, Be the season cold or hot.

Hast thou sighs, or hast thou not?

If thou hast no sighs or grones, Would thou hadst no flesh and bones! Lesser pains scape greater ones.

But if yet thou idle be,

Foolish soul, who di'd for thee? 
22. The death of the body and of the soul. Revelation xxi, 8. Cf. Man's Medley, III, 127, 1. 30.

24. Everything in this poem is antithetic: rivers and tears are offset against windes and sighs; Christ's life against his death; our losing gold against our finding silver; and all in illustration of the great antithesis of sin and salvation.

28. The present life, and the life of misery hereafter.

29. Can man properly take time to breathe between committing sin and accepting the new life offered by Christ's death?

32. $H$ is crosse $=$ his affliction.

33. Shall he not tell his Lord of his loss? 
Who did leave his Father's throne

To assume thy flesh and bone?

Had he life, or had he none?

If he had not liv'd for thee,

Thou hadst di'd most wretchedly,

And two deaths had been thy fee.

He so farre thy good did plot

That his own self he forgot.

Did he die, or did he not?

If he had not di'd for thee, Thou hadst liv'd in miserie.

Two lives worse then ten deaths be.

And hath any space of breath

'Twixt his sinnes and Saviour's death?

He that loseth gold, though drosse,

Tells to all he meets his crosse.

He that sinnes, hath he no losse?

He that findes a silver vein

Thinks on it, and thinks again.

Brings thy Saviour's death no gain?

Who in heart not ever kneels

Neither sinne nor Saviour feels. 
Date:

Not found in W.

\section{Metre:}

The same as that of The Church-Porch, except that this is a case of "link-verse," i. e. the last line of each stanza is the first line of the next, and the last line of the poem connects with the first. This structure, which at first seems merely ingenious, really expresses as no other could the selfperpetuating character of sin. Such beginnings touch their end. - Southwell in his St. Peter's Complaint, stanza cxiii (1595), has this stanza:

" My eye reades mournfull lessons to my hart,

My hart doth to my thought the greefes expound, My thought the same doth to my tongue impart,

My tongue the message in the eares doth sound; My eares back to my hart their sorrowes send; Thus circling greefes runne round without an end."

And Donne had already employed the device, though with far less delicacy and appropriateness, in his Corona or circlet of Divine Sonnets, where the last line of each is repeated as the first line of the next, and the last line of the seventh sonnet is the first line of the first. Several of Daniel's sonnets are similarly linked. In the following poem Herbert uses this metre with another fanciful modification of the last line.

SUBJECT:

Admit the beginnings of sin, and evil thoughts, words, and deeds follow in a never-ending round. 


\section{SINNES ROUND}

SorRIE I am, my God, sorrie I am

That my offences course it in a ring.

- My thoughts are working like a busie flame

Untill their cockatrice they hatch and bring. 4 And when they once have perfected their draughts,

- My words take fire from my inflamed thoughts. 
Notes:

4. For ancient beliefs about this fabulous monster, see Isaiah lix, 5, and xiv, 29. For both ancient and modern beliefs that "he proceedeth from a cock's egg, hatched under a toad or serpent, killeth at a distance and poisoneth by the eye," see Sir T. Browne's Vulgar Errors, III, 7. Spenser has him in The Amoretti, XLIX: "Kill with looks as cockatrices do."

8. Mount Aetna.

9. This rhyme occurs in three other poems.

10. To bring evil out into the air kindles its flame. anew. Cf. The Odour, III, 25, 1. 25.

12. So Jacula Prudentum: Sins are not known till they be acted.

15. Genesis xi, 4.

17. The same sinful sequence appears in Marie MagDALENE, III, 151, 1. 12. 
My words take fire from my inflamed thoughts, Which spit it forth like the Sicilian hill.

They vent the wares and passe them with their faults,

And by their breathing ventilate the ill.

But words suffice not where are lewd intentions;

My hands do joyn to finish the inventions.

My hands do joyn to finish the inventions. And so my sinnes ascend three stories high, As Babel grew before there were dissentions. 15 Yet ill deeds loyter not, for they supplie New thoughts of sinning. Wherefore, to my shame, Sorrie I am, my God, sorrie I am. 


\section{INTRODUCTORY :}

Dualism is deep in Herbert. His universe presents itself in antithetic pairs. Man and God, nature and spirit, pleasure and duty, death and life, - to these irreconcilable opposites his thought continually recurs. Between them he recognizes no inner kinship, as do Vaughan, Crashaw, and the Mystics. For him approach to the one is ever denial of the other. This pessimistic little poem, with its: two stanzas and contrasted endings, is an extreme exhibit of his temper.

Date:

Not found in W.

Metre:

A special adaptation of the metre of THE CHURCHPorch, II, 15, and Sinnes Round, III, 143. SubJect:

What befits affliction is not complaint, but repentance.

Notes:

6. Water pipes are mentioned also in WHITSUNDAY, II, 159, 1. 17. 


\section{THE WATER-COURSE}

Tноч who dost dwell and linger here below, Since the condition of this world is frail Where of all plants afflictions soonest grow,

If troubles overtake thee, do not wail;

For who can look for lesse that loveth $\left\{\begin{array}{l}\text { Life. } \\ \text { Strife. }\end{array}\right.$

But rather turn the pipe and water's course

To serve thy sinnes, and furnish thee with store Of sov'raigne tears, springing from true remorse; That so in purenesse thou mayst him adore 9 Who gives to man as he sees fit $\left\{\begin{array}{l}\text { Salvation. } \\ \text { Damnation. }\end{array}\right.$ 


\section{INTRODUCTORY :}

God's means of drawing us to himself. J. Churton Collins writes in his Treasury of Minor British Poetry: "This is the one poem of Herbert's which is not marred by his characteristic defects, affected quaintness, extravagance, prosaic baldness, and discordant rhythm." I cannot agree with this estimate. The poetry of Herbert does not seem to me in general to be marked with these characteristics, nor the present poem to be singularly free from them. Date:

Not found in W.

Metre:

Unique.

SuBJeCt :

"Thou hast made us for Thyself, and our heart is restless until it finds rest in Thee;" Augustine, Confessions, I, 1.

\section{Notes:}

7. These good gifts to man are often referred to by Herbert under slightly varying names: as in The World, II, 225; The Pearl, II, 381; The Quip, III, 33.

16, 17. Rest, restlessnesse. There are not above half-adozen puns in Herbert. Few poets of his day are so free from them. 


\section{THE PULLEY}

When God at first made man,

Having a glasse of blessings standing by,

Let us (said he) poure on him all we can.

Let the world's riches, which dispersed lie,

Contract into a span.

So strength first made a way,

Then beautie flow'd, then wisdome, honour, pleasure.

When almost all was out, God made a stay,

Perceiving that alone of all his treasure

Rest in the bottome lay.

For if I should (said he)

Bestow this jewell also on my creature,

He would adore my gifts instead of me, And rest in Nature, not the God of Nature.

So both should losers be.

Yet let him keep the rest,

But keep them with repining restlesnesse.

Let him be rich and wearie, that at least,

If goodnesse leade him not, yet wearinesse

May tosse him to my breast. 
Date:

Not found in $\mathbf{W}$.

Metre:

Unique. Rhyming system same as CHURCH-MonUMENTS, II, 201.

SubJECT:

The sinner must share, at least by tears, in his own cleansing.

Notes:

1. Luke vii, 38, and John xii, 3.

11. Tears like seas, again in The Size, III, 195, 1. 47.

12. This threefold aspect of $\sin$ is treated in SinNes Round, III, 143.

14. Dash = bespatter. 


\section{MARIE MAGDALENE}

When blessed Marie wip'd her Saviour's feet, (Whose precepts she had trampled on before,) And wore them for a jewell on her head, Shewing his steps should be the street

Wherein she thenceforth evermore

With pensive humblenesse would live and tread;

She being stain'd her self, why did she strive

To make him clean who could not be defil'd ?

Why kept she not her tears for her own faults,

And not his feet? Though we could dive 10

In tears like seas, our sinnes are pil'd

Deeper then they, in words, and works, and thoughts.

Deare soul, she knew who did vouchsafe and deigne

To bear her filth, and that her sinnes did dash Ev'n God himself; wherefore she was not loth, 15

As she had brought wherewith to stain,

So to bring in wherewith to wash.

And yet, in washing one, she washed both. 
Date:

Not found in W.

Metre:

Used also in The Crosse, III, 231.

SuBJECT:

The two greatest forces of the world and the least understood, Sin and Love, meet at their height in Christ's last hours; where the one had power to crush him in the Garden, the other to bring from his Cross life for all.

Notes:

3. Two strains of thought, as frequently with Herbert, blend in this expression: Scientific men have applied their measuring-rods to determine the distance of the earth from the stars. The use of the measuring-rod then suggests the staff in the hand of the traveller. Cf. Divinitie, III, 99, 1. 27. J. Howell, in a letter dated 1627, writes: “The philosopher can fathom the Deep, measure Mountains, reach the Stars with a Staff, and bless Heaven with a Girdle."

11. Perhaps an allusion to Isaiah lxiii, 3. Cf. Praise, III, 47, 1. 38.

15. Set abroach = set running. The word is used again in the same connection in Divinitie, III, 99, 1. 9.

18. John vi, 55. Cf. The Invitation, III, 49, l. 12. 


\section{THE AGONIE}

Philosophers have measur'd mountains,

Fathom'd the depths of seas, of states, and kings, Walk'd with a staffe to heav'n, and traced fountains;

But there are two vast, spacious things,

The which to measure it doth more behove, 5

Yet few there are that sound them: Sinne and Love.

Who would know Sinne, let him repair

Unto Mount Olivet; there shall he see

A man so wrung with pains that all his hair,

His skinne, his garments bloudie be.

Sinne is that presse and vice which forceth pain To hunt his cruell food through ev'ry vein.

Who knows not Love, let him assay

And taste that juice which on the crosse a pike

Did set again abroach; then let him say

If ever he did taste the like.

Love is that liquor sweet and most divine Which my God feels as bloud; but I, as wine. 
Date:

Not found in W.; but early in style.

Metre:

Unique.

SUBJECT:

The contrast between hearts and stones as regards their openness to Christ: the former should be tender, hospitable, clean, restful, impressible. Christ found only the latter so.

Notes:

5. I suppose this to mean, Our hearts have room enough, and to spare; and I so punctuate. But ed. 1633 reads our hearts good store, without comma or apostrophe.

9. Large, i. e. with room for sins and trifles by the score.

10. Whatever, the impatient interrogative $=$ what possible, what in the world, could the rock have done to need thee for its purification?

16. Order; a noun to be joined with quiet.

20. And therefore must employ stone. 2 Corinthians iii, 3.

23. Loving = from offering love to. 


\section{SEPULCHRE}

O BLESSED bodie! Whither art thou thrown? No lodging for thee but a cold hard stone? So many hearts on earth, and yet not one

Receive thee?

Sure there is room within our hearts-good store! For they can lodge transgressions by the score. Thousands of toyes dwell there, yet out of doore They leave thee.

But that which shews them large, shews them unfit. Whatever sinne did this pure rock commit, 10 Which holds thee now? Who hath indited it Of murder?

Where our hard hearts have took up stones to brain thee,

And missing this, most falsly did arraigne thee, Onely these stones in quiet entertain thee, And order.

And as of old, the law by heav'nly art Was writ in stone; so thou, which also art The letter of the word, find'st no fit heart

To hold thee.

Yet do we still persist as we began, And so should perish, but that nothing can, Though it be cold, hard, foul, from loving man Withold thee. 


\section{INTRODUCTORY :}

This curious piece is more like Giles Fletcher's work than anything else of Herbert's. It approaches its subject from the side of God and not of man, reporting heavenly events rather than - as is Herbert's way - human longings. Its style, too, is Fletcher's, treating the gravest matters sweetly and with a kind of sportive romance. Fletcher preceded Herbert both at Westminster School and Trinity College by only four years. His poem, Christ's Victories, was published in 1610. $-B_{A G}=$ mail-bag.

Date:

Not found in W.

Metre:

Unique.

SUbJeCt:

We cannot despair, since Christ is open to all our desires. Christ's wounded side seems greatly to have impressed Herbert. Allusions to it occur in The Sacrifice, II, 147, 1. 246; Prayer, II, 181, 1. 6; H. Baptisme, II, 191, 1. 6; Divinitie, III, 99, 1. 9; The Agonie, III, 153,1. 14; The Church Militant, III, 363, 1. 69.

\section{Notes:}

5. The reference of this stanza is to the storm on the Sea of Galilee. Matthew viii, 24 .

6. Well = possibly, as in H. Communion, II, 197, 1. 31. 


\section{THE BAG}

Away despair! My gracious Lord doth heare.

Though windes and waves assault my keel, He doth preserve it; he doth steer,

Ev'n when the boat seems most to reel.

Storms are the triumph of his art.

Well may he close his eyes, but not his heart.

Hast thou not heard that my Lord Jesus di'd ?

Then let me tell thee a strange storie.

The God of power, as he did ride

In his majestick robes of glorie,

Resolv'd to light; and so one day

He did descend, undressing all the way.

The starres his tire of light and rings obtain'd, The cloud his bow, the fire his spear, The sky his azure mantle gain'd.

And when they ask'd what he would wear, He smil'd and said, as he did go, He had new clothes a making here below. 
15. In early Christian art the outer mantle of Christ is always blue, his inner tunic red; the latter color signifying love, the former wisdom. This seems to be the reason for the employment of azure in Humilitie, II, 239, 1. 2.

18. Cf. Hebrews ii, 17.

20. Luke ii, 7.

26. John xix, 34.

28. $M a n=$ guard, attendant. This poem has inspired Vaughan's Incarnation and Passion.

42. So 1.1. 
When he was come, as travellers are wont,

He did repair unto an inne.

Both then and after, many a brunt

He did endure to cancell sinne.

And having giv'n the rest before,

Here he gave up his life to pay our score.

But as he was returning, there came one

That ran upon him with a spear.

He who came hither all alone,

Bringing nor man, nor arms, nor fear,

Receiv'd the blow upon his side;

And straight he turn'd and to his brethren cry'd,

If ye have anything to send or write,

(I have no bag, but here is room)

Unto my father's hands and sight

(Beleeve me) it shall safely come.

That I shall minde what you impart,

Look, you may put it very neare my heart.

Or if hereafter any of my friends

Will use me in this kinde, the doore

Shall still be open; what he sends

I will present, and somewhat more,

Not to his hurt. Sighs will convey

Any thing to me. Heark despair, away! 
Date:

Not found in W.

Metre:

Of seventeen sonnets, eleven - like this - depart in the third quatrain from the Shakespearian form. SubJect:

Similarities of language often correspond with similarities of meaning. See I, 165.

Notes:

3. The rising admiration for the vernacular had been expressed by Sidney in his Defence of Poesie: "Some will say ours is a mingled language: and why not so much the better, taking the best of both the other? For the uttering sweetly and properly the conceit of the mind, which is the end of speech, that hath it equally with any tongue in the world."

4. Cf. The Church-Ponch, II, 43, 1. 239.

8-10. When the light of life grows dim in parents, their fruit or issue takes it up, passing the flame along from Adam in Paradise to the latest generation among Western tribes. So in The Church MruTANT, III, 359, 365, 1. 17, 97. Is there an allusion here to Plato's torch-race? Repub. I, 328.

14. So, too, Even-Song, III, 59,1. 8. But Herbert shows forbearance in not playing on this double meaning in his Sunday, II, 175 - as did Vaughan afterwards. Donne, too, writes: "Joy at th' uprising of this Sunne and Son:" La Corona, VII, 2. 


\section{THE SONNE}

LET forrain nations of their language boast, What fine varietie each tongue affords,

I like our language, as our men and coast. Who cannot dresse it well, want wit, not words. How neatly doe we give one onely name

To parents' issue and the sunne's bright starre!

A sonne is light and fruit; a fruitful flame

Chasing the father's dimnesse, carri'd farre

From the first man in th' East to fresh and new

Western discov'ries of posteritie.

So in one word our Lord's humilitie

We turn upon him in a sense most true:

For what Christ once in humblenesse began, We him in glorie call, The Sonne of Man. 
Date:

Not found in W.

Metre:

Unique.

SubJeCt:

Wherever love and gladness are, there too is Christ. But the association of Christ with the vine is also in Herbert's mind.

Notes:

1, 3. Window and anneal'd. The conditions assumed in this poem are these: A church window of stained glass (for anneal'd, see The Windows, III, 15, 1. 6) bears the design of the True Vine (John xv, 1). A section of the repeated pattern (cf. every, 1.3) shows a group of stem, leaves, and drooping grapes. The tendrils, curling in opposite directions, suggest by their forms to Herbert's eye the opposed curves of the letters $J$ and $C$; while the bodie, or material suggestion of the vine, brings to his mind thoughts of festivity and human fellowship. This double suggestion is confirmed by him who understands both the window and the sources of joy.

5. This forward trait of Herbert's character is again referred to in The Answer, II, 351, 1. 6. 


\section{LOVE-JOY}

As on a window late $I$ cast mine eye,

I saw a vine drop grapes with $J$ and $C$ Anneal'd on every bunch. One standing by Ask'd what it meant. I (who am never loth

To spend my iudgement) said, It seem'd to me To be the bodie and the letters both

Of Joy and Charitie. Sir, you have not miss'd, The man reply'd: It figures JESUS CHRIST. 
INTRODUCTORY :

In B. this is placed between CHURCH-Musick and Church-Lock AND KEY. R. Southwell writes in Our Ladies Salutation:

"Spell Eva backe, and ave shall you finde.

The first beganne, the last reversed our harmes."

"An anagram is the transposition of the letters of a word so as that, without the omission or repeating of any letter, they compose another of quite different signification. Poets have been generally fond of this scrap of ingenuity and have always used it to the improvement or disgrace of what the word primarily signified:” G. Ryley (1714).

DATE:

Not found in W.

Notes:

2. Perhaps a reminiscence of Hebrews viii, 2 . 


\section{ANA- $\left\{\begin{array}{l}\text { MARY } \\ \text { ARMY }\end{array}\right\}$ GRAM}

How well her name an Army doth present In whom the Lord of hosts did pitch his tent! 
DATE:

Not found in W.

METRE:

Unique. With wide rhymes, $-1.3,9$, and 6, 12. SubJECT:

"Ye are the temple of God:" 1 Corinthians iii, 16. Notes:

1. Floore, the groundwork of religion.

7. This poem cannot have been suggested by Salisbury Cathedral, whose choir is on a level with the nave.

10. Colossians iii, 14.

14. Neat $=$ delicate.

15. The marble weeps. So Grieve Not, III, 257, 1. 23, and a variation in The Church Porch, II, 63, 1. 417. Cf. Milton's Hymn on Christ's Nativity, 1. 195: "And the chill marble seems to sweat."

16. A modification of this figure is used in CHurchMonuments, II, 201, 1. 4. 


\section{THE CHURCH-FLOORE}

Mark you the floore? That square and speckled stone,

Which looks so firm and strong,

Is Patience.

And th' other black and grave, wherewith each one

Is checker'd all along,

Humilitie.

The gentle rising, which on either hand

Leads to the Quire above,

Is Confidence.

But the sweet cement, which in one sure band 10 Ties the whole frame, is Love And Charitie.

Hither sometimes Sinne steals, and stains

The marble's neat and curious veins;

But all is cleansed when the marble weeps.

Sometimes Death, puffing at the doore,

Blows all the dust about the floore;

But while he thinks to spoil the room, he sweeps.

Blest be the Architect whose art

Could build so strong in a weak heart. 20 


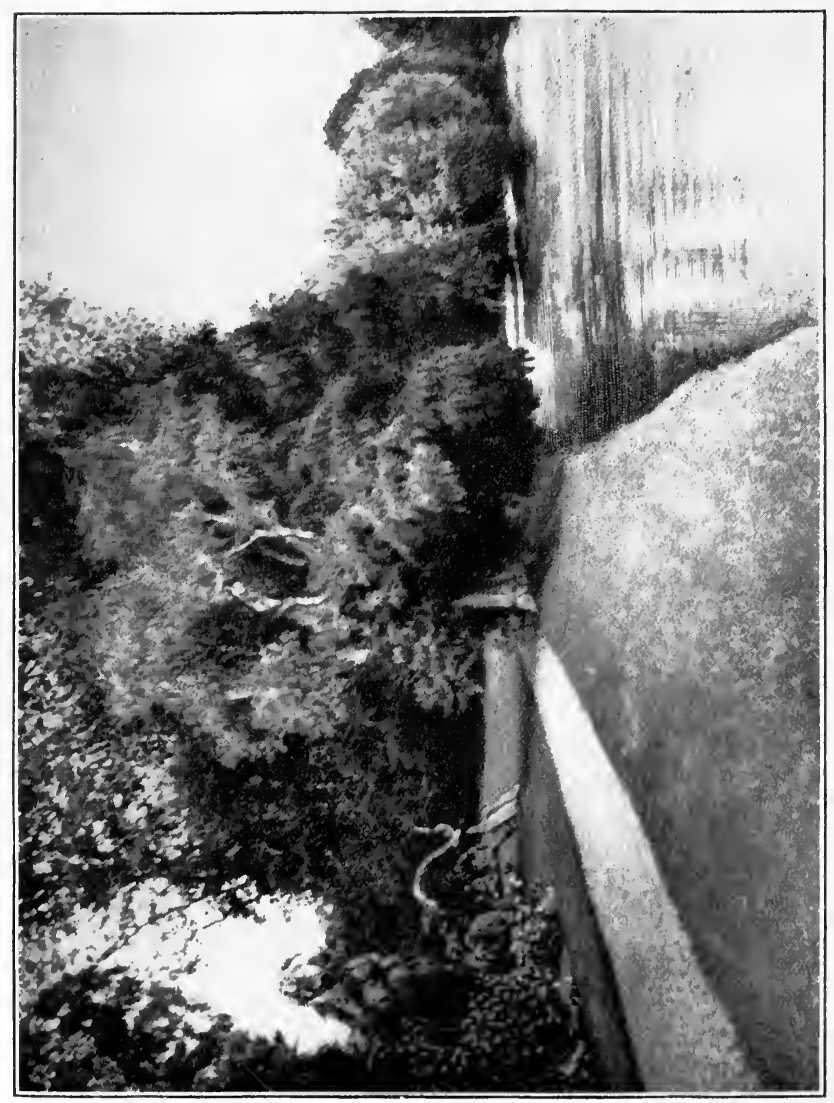





\section{IX}

\section{RESTLESSNESS}





\section{PREFACE}

THERE came a reaction. The little parish ' 1 which had seemed so attractive in its isolation, and into which Herbert had thrown himself with such joyful eagerness, proved painfully small. • For thirty-seven years he had lived in the full tide of affairs. Born in high station, he had found his associates among the leaders of the day. With the gayest, the most learned, the most widely influential men of his time, Herbert had long been living on terms of intimacy, and from them had derived much of that ability to write fine and wittie on which to the last he prided himself. Inaction had . always been in his eyes the most dreaded of evils. Yet for the rest of his life he was to be cut off from society. He was to minister to a small group of farm laborers in a village remote from city, court, and university. His predecessor had not endured such conditions; but leaving church and parsonage in decay, had lived "at a better Parsonage house sixteen or twenty miles from this place."

At first the restrictions of Herbert's surroundings were not irksome. After the storms of the Crisis period he found peace in sacred tasks and in what he supposed to be a settled mind. It seemed as if 
at length he past changing were, Fast in God's Paradise, where no flower can wither. According to Walton, he remarked to a friend just after his Induction: I now look back upon my aspiring thoughts, and think myself more happy than if I had attain'd what then I so ambitiously thirsted for. In God and his service is a fulness of all joy and pleasure, and no satiety. Vóluntarily cut off from outward activities, we have seen him joyfully . developing every possibility within his own narrow bounds. He explores his priestly duties; he calls on the services of his Church to disclose their inmost significance; he records with double diligence the moods of his soul. While it is not necessary to suppose that a majority of his poems were produced in these three years, still the early manuscript contains only a minority; and a large proportion of those which first appear in the later manuscript allude to the priestly office. Herbert's art must, therefore, have been busily pursued during this time of seclusion. A kindred art he also had. "His chiefest recreation was Musick, in which heavenly Art he was a most excellent Master, and did himself compose many divine Hymns and Anthems which he set and sung to his Lute or Viol. And though he was a lover of retiredness, yet his love of Musick was such that he went usually twice every week on certain appointed days to the Cathedral Church in Salisbury; and at his return would say that his time spent in 
Prayer and Cathedral Musick elevated his Soul and was his Heaven upon Earth. But before his return thence to Bemerton, he would usually sing and play his part at an appointed Musick-meeting."

Such were the occupations accessible in his small parish. For one who had always lived at the centre of men and things, the change experienced could not fail to be great. It had its welcome and unwelcome sides, corresponding to the diversities in Herbert's own nature. With one side of himself - the Elizabethan and Renaissance side - he loved gayety, pleasure, great place, intellectual companionship, the stir and glitter of the world. With the other side, which connected him with the early half of the seventeenth century, he loved - profoundly and tenderly loved - an abstract and exclusive God, the guardian of unity, order, obedience, silence, one hostile to every species of earthly attachment. We have seen how on entering the priesthood he anticipated that in this divine love there could be no satiety. He did not find it so. The conflicts of the Crisis were renewed. Human . interests, personal desires, had never died in Herbert. They never did die. That is what makes him so attractive a figure. He is ever a struggling soul, eager for God and unity, but only less eager to make the wealthy world his own. He is no calm saint. Nobody can read the stormy poems of this Group and find the epithet appropriate which has 
been connected with his name by loose admirers in his and our age. Herbert is not holy. There was always a noise of thoughts within his heart. However closely joy was locked up, some bad man would let it out again. He was continually asking of God whether it were not better to bestow some place and power on him; and years spent in cold dispute of what is fit and not were apt to appear as only lost. Many will feel that this failure of inward unity was due to the separatist notions under which Herbert for the most part thought of God, conceiving Him not as immanent in human affairs, but as detached and hostile. No doubt this is true; but it does not make the conflict in Herbert's soul less real or instructive. Some readers, remembering the literary habits of Herbert's age and the sonnets of its love-poets, may suspect that the extent of the conflict is exaggerated in the interests of dramatic art. But even so he paints a conflict judged appropriate to the situation. However we approach these most human of Herbert's songs, we shall find that in them justice is done to sides of life from which the saint instinctively turns. Man is a Medley; and Herbert, never the simple and "holy" person of popular tradition, depicts that medley with sympathetic vividness.

The Group begins with one of the greatest of his autobiographic poems; and ends with another, more allegoric, but even more detailed and confessional in character. In Love Unknown Her- 
bert treats imaginatively the three periods of his manhood. Though he knew himself destined for the priesthood, his heart was first centred on Academic and royal honors. A dish of such fruit he gained, intending eventually to offer it to the Lord. (This dignity hath no such earthiness in it but it may very well be joined with heaven: Herbert to Sir J. Danvers, 1619.) But his heart needed to be detached from these things and cleansed. Then came the deaths of his friends and mother (a sacrifice out of his fold, 1. 30), the resignation of his Oratorship, and his severe illness. These afflictions fell upon him when cold toward God,-hard of heart as regards his own appointed work. Becoming supple through affliction and through a taste of God's forgiving love, he turned to that priesthood and home where he had always expected rest. But even in Bemerton he finds dull conditions and goading thoughts. According to this interpretation, the present poem would resurvey at a later date the career already sketched in AfFuiction, II, 339, which is here referred to in 1.28. A more detailed but similar account is given in ThE PILgrimage. In The Familie, The Discharge, The Size, and The Method he considers reasons for contentment; in HOPE he perceives how inadequate these are; in Submission we hear of the painful contrast between the empty life at Bemerton and that to which he had aspired, a contrast resulting in the Dulnesse of the next poem 
and the rebellious mood of The Collar. The sense that in the service of God there is little rewarding joy suggests in the next three poems that God has withdrawn his favor, and gives rise to tender lament. Conscience insists on obedience. But in one of the most pathetic poems of the series, The Crosse, we learn how partly through illness, and partly through a restless heart, the priesthood is proving a disappointment. 
RESTLESSNESS 
INTRODUCTORY:

"This poem is a striking example and illustration that the characteristic fault of our elder poets is the reverse of that which distinguishes too many of our recent versifiers: the one conveying the most fantastic thoughts in the most correct and natural language; the other in the most fantastic language conveying the most trivial thoughts. The latter is a riddle of words, the former an enigma of thoughts:" Coleridge, Biog. Lit. XIX.

\section{DAte:}

Not found in W.

Metre:

Used also in A Wreath, II, 319, and Grief, III, 323.

SubJect :

Unperceived by us, the severities of God express his love and wisdom. John xiii, 7.

\section{Notes:}

1. This is the only poem in which Herbert professes to speak with a friend; and the friend is but another mood of Herbert himself (1. 11).

3. Complie=join, sympathize.

4. Cf. Redemption, II, 237, 1. 1.

5. For the two lives see MaN's Meduex, III, 125.

6-18. Cf. An Offering, II, 393, 1. 3-5.

6. The Cambridge scholarship and poetry.

8. A similar partition of a poem by refrains occurs in The Church Militant, III, 361, 1. 48. 


\section{LOVE UNKNOWN}

Deare Friend, sit down, the tale is long and sad, And in my faintings I presume your loue

Will more complie then help. A Lord I had, And have, of whom some grounds which may improve

I hold for two lives, and both lives in me. 5 To him I brought a dish of fruit one day, And in the middle plac'd my heart. But he

(I sigh to say).

Lookt on a servant who did know his eye

Better then you know me, or (which is one) 10 Then I my self. The servant instantly,

Quitting the fruit, seiz'd on my heart alone And threw it in a font wherein did fall

A stream of bloud which issu'd from the side Of a great rock. I well remember all

And have good cause. There it was dipt and di'd,

And washt and wrung; the very wringing yet

Enforceth tears. Your heart was foul, I fear.

Indeed ' $t$ is true. I did and do commit

Many a fault more then my lease will bear, 20 Yet still askt pardon and was not deni'd.

But you shall heare. After my heart was well, And clean and fair, as I one even-tide

(I sigh to tell) 
14. Here, as in the popular hymn, Rock of Ages, there appears to be a double allusion to the striking of the rock by Moses and the piercing of Christ's side. Numbers xx, 11, and John xix, 34: A similar blending occurs in The Sacrifice, II, 139, 1. 170.

22. Was well. Cf. Affliction, II, 343, 1. 31. When my heart was cleansed of desire for worldly honor and I had decided on the priesthood.

25. Walkt by my self abroad, the Crisis period.

28. Herbert has five poems with this title. The reference here is to the one in II, 341, written after the death of his mother.

40. Matthew xxvi, 28.

42. Cf. The Invitation, III, 49, 1. 12.

43. For good=for my good. The church ordinances, which to those around me were routine matters, had gained for me an inner meaning, in which as a priest I hoped now to rest. 
Walkt by my self abroad, I saw a large

And spacious fornace flaming, and thereon

A boyling caldron round about whose verge

Was in great letters set AFFLICTION.

The greatnesse shew'd the owner. So I went

To fetch a sacrifice out of my fold,

Thinking with that which I did thus present

To warm his love, which I did fear grew cold.

But as my heart did tender it, the man

Who was to take it from me slipt his hand

And threw my heart into the scalding pan-

My heart, that brought it (do you understand?)

The offerer's heart. Your heart was hard, I fear.

Indeed ' $t$ is true. I found a callous matter

Began to spread and to expatiate there;

But with a richer drug then scalding water

I bath'd it often, ev'n with holy bloud, Which at a board, while many drunk bare wine,

A friend did steal into my cup for good, Ev'n taken inwardly, and most divine

To supple hardnesses. But at the length 45

Out of the caldron getting, soon I fled

Unto my house, where to repair the strength

Which I had lost, I hasted to my bed.

- But when I thought to sleep out all these faults (I sigh to speak) $\quad 50$ 
51. Home and the quiet of Bemerton brought restless thoughts.

55. Cf. Church-Lock and Key, II, 301, 1. 1.

56. The dulnesse which is lamented in the poem of that name, III, 207.

59. So The Method, III, 197, 1. 15.

60. The Bag, III, 159, 1. 24.

70. In these adjectives are summed up some of the most constant desires of Herbert and of his age,to be ever fresh, sensitive, and alert,- desires which in Herbert's case were continually thwarted by feeble health. 
I found that some had stuff'd the bed with thoughts, I would say thorns. Deare, could my heart not break,

When with my pleasures ev'n my rest was gone? Full well I understood who had been there, For I had giv'n the key to none but one. 55

It must be he. Your heart was dull, I fear. Indeed a slack and sleepie state of minde Did oft possesse me, so that when I pray'd, Though my lips went, my heart did stay behinde. But all my scores were by another paid, 60 Who took the debt upon him. Truly, Friend,

For ought I heare, your Master shows to you More favour then you wot of. Mark the end:

The Font did onely what was old renew, 64 The Caldron suppled what was grown too hard,

The Thorns did quicken what was grown too dull, All did but strive to mend what you had marr'd.

Wherefore be cheer'd, and praise him to the full Each day, each houre, each moment of the week, Who fain would have you be new, tender, quick. 
Date:

Not found in W. He finds murmurings lurking in his priestly heart.

Metre:

Unique.

SubJeCt:

Peace, Silence, Order, Obedience, Joy, Grief, are the true members of God's Household.

Notes:

2. A part, a musical part; as noise in the preceding line is probably intended for jarring music. So Aaron, III, 11, 1. 8.

4. Rule or eares. Rule refers to pulling, in the previous line, and eares to loud.

5. Cf. MaN, II, 215, 1. 2-4.

7. Mark xi, 15-17.

8. Neat=refinedly beautiful. So MAN, II, 221, 1. 42.

10. Plaies. The preposition is omitted, as when we speak of playing the harp.

12. The rank growths of the soul are brought into order. Cf. Paradise, III, 39.

20. Shrill=penetrating. Milton's "Shrill matin song," Par. Lost, V,7. But that the expression was a daring one, even for Herbert, is plain from Vaughan's repeating it in the first line of his Admission: "How shrill are silent tears!" 


\section{THE FAMILIE}

What doth this noise of thoughts within my heart, As if they had a part?

What do these loud complaints and pulling fears, As if there were no rule or eares?

But, Lord, the house and familie are thine,

Though some of them repine.

Turn out these wranglers which defile thy seat,

For where thou dwellest all is neat.

First Peace and Silence all disputes controll, Then Order plaies the soul;

And giving all things their set forms and houres,

Makes of wilde woods sweet walks and bowres.

Humble Obedience neare the doore doth stand,

Expecting a command;

Then whom in waiting nothing seems more slow,

Nothing more quick when she doth go.

Joyes oft are there, and griefs as oft as joyes,

But griefs without a noise;

Yet speak they louder then distemper'd fears.

What is so shrill as silent tears?

This is thy house, with these it doth abound.

And where these are not found,

Perhaps thou com'st sometimes and for a day,

But not to make a constant stay. 
Date:

Not found in W. He finds himself reprehensibly wondering if he has been wise in taking orders.

Metre:

Unique, but differs only in rhyming system from JUDGEMENT, II, 271.

SUBJECT:

Having now committed myself to God, let anxieties cease. Away, distrust! Matthew vi, 25-34. . Notes:

3. "Licorous, probably from the licking of the lips of men and animals when slavering and greedy-desirous; and is metaphorically applied to the eyes. Lecherous is in fact the same word, but more confined by present custom to one form of desire:" A. B. Grosart. He that for quality is licorous after dainties is a glutton: Country Parson, XXVI.

8. Depart=dispense, part with. Cf. Oredience, II, 385,1 . 8. Throughout this poem there is constant reference to OBEDIEnce, where his decision to become a priest was originally reached.

11. Is gone $=$ is determined already by your past act.

13. Exodus xiii, 21.

16. This = the disasters and comforts of the Crisis time. He made thee a priest, as in 1.11 . 


\section{THE DISCHARGE}

BusIE enquiring heart, what wouldst thou know? Why dost thou prie, And turn, and leer, and with a licorous eye Look high and low, And in thy lookings stretch and grow? 5

Hast thou not made thy counts and summ'd up all?

Did not thy heart

Give up the whole and with the whole depart?

Let what will fall, That which is past who can recall? 10

Thy life is God's, thy time to come is gone, And is his right.

$\mathrm{He}$ is thy night at noon, he is at night Thy noon alone.

The crop is his, for he hath sown. 15

And well it was for thee, when this befell, That God did make Thy businesse his, and in thy life partake; For thou canst tell, If it be his once, all is well. 
22-25. Fortunate to know what the present demands, without cudgelling your brains over the future.

30. It will grow fast enough without your digging for it. 31. Provide =look forward. .

32. "The reverse of going upon or acting on the square =acts disloyally, breaks the agreement that the present is his and the future his God's:" A. B. Grosart. John the Baptist squared out [i. e. assigned] to every one what to do: Country Parson, XXXII.

34. Same use of wide in H. Baptisme, II, 191, 1. 8.

39. Those grounds=the future, separated from us by death. 
Onely the present is thy part and fee.

And happy thou

If, though thou didst not beat thy future brow,

Thou couldst well see

What present things requir'd of thee. 25

They ask enough. Why shouldst thou further go?

Raise not the mudde

Of future depths, but drink the cleare and good.

Dig not for wo

In times to come, for it will grow. 30

Man and the present fit; if he provide,

He breaks the square.

This houre is mine; if for the next I care,

I grow too wide,

And do encroach upon death's side. 35

For death each houre environs and surrounds.

He that would know

And care for future chances, cannot go

Unto those grounds

But through a Church-yard which them

bounds. 
45. "The phrase is taken from tilting a cask on end to get all out of the tap:" A. B. Grosart. This does not fit the context, which requires that an end shall mean at great length. The explanation is found in an early use of bottom in the sense of a spool or holder on which thread is wound. So Herbert uses it in 1622 in a letter to his mother in her sickness: I have alwaies observ'd the thred of life to be like other threds or skenes of silk, full of snarles and incumbrances. Happy is hewhose bottome is wound upand laid ready for work in the New Jerusalem. The New English Dictionary cites an example from Ralegh's History of the World: "He receiveth from her [Ariadne] a bottom of thread." The meaning here accordingly is that, by anticipating, men pull an end from the spool of grief and unroll the whole ball. And this, so far from putting away the trouble, gives length to it. The same figure is applied in a different way in The Church-Porch, II, 29, 1. 124. The word may possibly have a similar meaning in Church-Rents and Schismes, III, 105, 1. 6.

46. Causes of fear are tied up in the future. Do not release them, 1.48 , nor make to-morrow sad. Our proverb says: "Let sleeping dogs lie."

54. So The BAg, III, 157 1. 1. 
Things present shrink and die. But they that spend

Their thoughts and sense

On future grief, do not remove it thence,

But it extend,

And draw the bottome out an end.

God chains the dog till night. Wilt loose the chain, And wake thy sorrow?

Wilt thou forestall it, and now grieve tomorrow,

And then again

Grieve over freshly all thy pain?

Either grief will not come, or if it must,

Do not forecast.

And while it cometh it is almost past.

Away distrust!

My God hath promis'd, he is just. $\quad 55$ 


\section{INTRODUCTORY :}

How great may one be who would also be a servant of God? Size is used in this sense in FaITH, II, 235, 1. 28, and in The Rose, II, 389, 1. 4.

\section{DATE:}

Not found in W. He is trying to adjust himself to narrow conditions.

METRE:

Unique.

\section{SuBJECT:}

In this world there come to the Christian small joys, - and it is well.

Notes:

5,6 . As streams in the lowlands are kept alive by waters higher up, so let your gentle joys be stirred by those on high.

7. Fraught=freight.

9. Enough pleasure to render grief endurable.

21. Those have. The great joys are already in possession of their hopes.

22. On score, i. e. on trust, as in THE BAG, III, 159, 1. 24. 


\section{THE SIZE}

Content thee, greedie heart.

Modest and moderate joyes to those that have

Title to more hereafter when they part,

Are passing brave.

Let th' upper springs into the low

Descend and fall, and thou dost flow.

What though some have a fraught

Of cloves and nutmegs, and in cinamon sail;

If thou hast wherewithall to spice a draught,

When griefs prevail,

And for the future time art heir

To th' Isle of spices, is't not fair?

To be in both worlds full

Is more then God was, who was hungrie here.

Wouldst thou his laws of fasting disanull? 15

Enact good cheer?

Lay out thy joy, yet hope to save it?

Wouldst thou both eat thy cake and have it?

Great joyes are all at once,

But little do reserve themselves for more.

Those have their hopes; these what they have renounce,

And live on score. .

Those are at home, these journey still

And meet the rest on Sion's hill. 
25. Luke vi, 24-26.

29. Cf. Affliction, II, 339, 1. 10.

35. The split infinitive is rare in Herbert's verse. I have not found another instance.

36. Like one still in pursuit, not in assured and happy possession. Pretend is used in this sense in UNKINDNESSE, II, 309, 1. 16.

38. 1 Timothy vi, 10.

40. An absent line here, omitted both in 1632 and in B., is thus supplied by Dr. Grosart: At all times fall. Ernest Rhys proposes: Did always fall.

41. Instead of reckoning time from the last great storm, some joy would mark our epoch.

42. Dr. Grosart thinks seam is used here in the sense of pocket. Do not expect to pocket up blessings.

46. An emblem, like those described by Quarles, or like that of Hope, III, 203. 
Thy Saviour sentenc'd joy,

And in the flesh condemn'd it as unfit,

At least in lump, for such doth oft destroy;

Whereas a bit

Doth tice us on to hopes of more, And for the present health restore.

A Christian's state and case

Is not a corpulent, but a thinne and spare

Yet active strength; whose long and bonie face

Content and care

Do seem to equally divide -

Like a pretender, not a bride.

Wherefore sit down, good heart.

Grasp not at much, for fear thou losest all.

If comforts fell according to desert,

They would great frosts and snows destroy;

For we should count, Since the last joy.

Then close again the seam

Which thou hast open'd. Do not spread thy robe

In hope of great things. Call to minde thy dream,

An earthly globe,

On whose meridian was engraven,

These seas are tears, and heav'n the haven. 
Date:

Not found in W. He questions why he is not nearer God.

Metre:

Used also in Good Friday, II, 149, but with different rhyming system.

SubJect :

Our method of treating God, and his of treating us. A slight early sketch of this theme is found in Church-Lock AND KeY, II, 301.

Notes:

3. $R u b=$ hindrance. Hamlet's, "Ay, there's the rub:" iii, 1.

6. $M o v e=$ propose, used much as in parliamentary proceedings. So motion is used in 1.19 and 23. Cf. Praise, II, 397, 1. 4, The Call, III, 9, 1. 10, and Perseverance, III, 395,1.3. Lord Herbert entitles one of his poems An Ode on a Question Moved Whether Love Should Continue For Ever.

10. Tumble thy breast; so СHurch-Porch, II, 31, 1. 148.

15. So Love Unknown, III, 183, 1. 59. 


\section{THE METHOD}

Poore heart, lament.

For since thy God refuseth still,

There is some rub, some discontent,

Which cools his will.

Thy Father could

Quickly effect what thou dost move,

For he is Power; and sure he would,

For he is Love.

Go search this thing,

Tumble thy breast and turn thy book.

If thou hadst lost a glove or ring,

Wouldst thou not look?

What do I see

Written above there? Yesterday

I did behave me carelesly

When I did pray. 
18. Indifferents $=$ careless persons.

23. I conceive the restraining motions are much more frequent to the godly then inviting motions : To THE 49th Consideration of Valdesso.

27. The rhyme was already used in 1. 19. 
And should God's eare

To such indifferents chained be

Who do not their own motions heare?

Is God lesse free?

But stay! What's there?

Late when I would have something done, $I$ had a motion to forbear,

$Y$ et I went on.

And should God's eare,

Which needs not man, be ty'd to those

Who heare not him, but quickly heare

His utter foes?

Then once more pray.

Down with thy knees, up with thy voice. 30 Seek pardon first, and God will say,

Glad heart rejoyce. 


\section{HOPE}

INTRODUCTORY :

Emblems, both of word and picture, were much in fashion in Herbert's day. Quarles' Emblems (1635) well met the current taste. An emblem engraved upon a ring similar to the emblems mentioned here was sent to Herbert by Dr. Donne. It is described in Walton's Life, and in Herbert's verses of acknowledgment, III, 401. According to the prints of it that have come down to us, it had on one side an anchor used as a cross, and on the other side a growing plant bearing a few green eares. If this poem was in any way suggested by Donne's seal, its date is not earlier than 1630-31. Walton says the seals were engraved a little before Donne's death in 1631. About the interpretation of this poem there are discussions in Notes and Queries, IX, 154; X, 18, 333.

Date:

Not found in W.

Metre:

Unique. 


\section{SUBJECT:}

Herbert's constant subject, the contradictions of love, which may here be entitled The Weariness of Hope. It is the theme of The Colluar, III, 211, but does not, like that poem, find a conclusion in the acceptance of love.

To Love I gave my time, prayers, tears. Serving Love long and getting small return, I remind him of time passing, prayers offered, tears shed. Still he gives only hopes, visions, immature fruit. I despair. Translating into abstract terms Herbert's imagery of things, the sequence of his thought might be represented thus:

To Love I said, "Hast thou forgotten Time?"

"Time counts for naught with Love, for Love is Hope." But I prayed still the prayer I ever prayed.

"Look far away," said Love, "Not on things near." I wept.

"Nay, here and now is fruit," he said. "Unripe, indeed." "Why such delay?" cried I. "Give all or none!" 
Notes:

2. Hebrews vi, 9.

4. Optick=telescope. The word occurs again in the lines To the Queene of Bohemia, III, 425, l. 13. Milton, remembering Galileo, speaks of "The moon whose orb Through optic glass the Tuscan artist views:" Par. Lost, I, 287.

5. Cf. Praise, III, 47, 1. 27. 


\section{HOPE}

I GAVE to Hope a watch of mine; but he An anchor gave to me.

Then an old prayer-book I did present;

And he an optick sent.

With that I gave a viall full of tears;

But he a few green eares.

Ah Loyterer! I'le no more, no more I'le bring.

I did expect a ring. 
DATE:

Not found in W. His hopes of greatness blighted in Bemerton parish.

Metre:

Used also in The 23 Psalme, III, 19. SuBJECT:

The ambitious heart, knowing its blindness, reluctantly accepts the small appointed work. Notes:

2. My power and right of judgment are given up to God.

4. My designe, i. e. of political preferment.

10. My private judgment, 1. 2.

12. Disseize = dispossess. Love, II, 85, 1. 26.

17. Gift; cf. 1.2 and 11.

19. The same thought occurs again in OBedience, II, 387, 1. 23-25. Psalm exxxix, 10. 


\section{SUBMISSION}

BUT that Thou art my wisdome, Lord,

And both mine eyes are thine,

My minde would be extreamly stirr'd

For missing my designe.

Were it not better to bestow

Some place and power on me?

Then should thy praises with me grow,

And share in my degree.

But when I thus dispute and grieve,

I do resume my sight,

And pilfring what I once did give,

Disseize thee of thy right.

How know I, if thou shouldst me raise,

That I should then raise thee?

Perhaps great places and thy praise

Do not so well agree.

Wherefore unto my gift I stand;

I will no more advise.

Onely do thou lend me a hand,

Since thou hast both mine eyes. 


\section{Date:}

Not found in W. Mental inertness deplored. Metre:

Used also in Giddinesse, III, 129.

\section{SubJect:}

Why, when gay wits celebrate their mistresses on every trivial occasion, have I such torpor in honoring my love? A first sketch of The ForenuNNERS, III, 317.

Notes:

3. Quicknesse = vivacity of mind (1. 25).

7. The phrase is repeated in Jordan, II, 91, 1. 5.

12. As truly as the fairest fair (1. 6). 


\section{DULNESSE}

Why do I languish thus, drooping and dull, As if I were all earth?

$O$ give me quicknesse, that I may with mirth Praise thee brim-full!

The wanton lover in a curious strain 5

Can praise his fairest fair, And with quaint metaphors her curled hair Curl o're again.

Thou art my lovelinesse, my life, my light,

Beautie alone to me. 10

Thy bloudy death and undeserv'd makes thee Pure red and white. 
13. Taking up again 1.10.

14. A parenthetic line - And that perfection those which, etc.

18. For a window-song, Dr. Grosart refers to Sidney's Astrophel and Stella, LIII.

19. Pretending = stretching forth, aspiring, as in JoRDAN, II, 93, 1. 16.

21. Sugred lyes. The phrase is used also in The Rose, II, 389, 1. 2 . 
When all perfections as but one appeare That, those thy form doth show The very dust where thou dost tread and go Makes beauties here.

Where are my lines then? My approaches? Views?

Where are my window-songs?

Lovers are still pretending, and ev'n wrongs Sharpen their Muse.

But I am lost in flesh, whose sugred lyes Still mock me and grow bold. Sure thou didst put a minde there, if $I$ could Finde where it lies.

Lord, cleare thy gift, that with a constant wit

I may but look towards thee.

Look onely; for to love thee, who can be,

What angel fit? 
INTRODUCTORY :

THE COLLAR = restraint.

Date:

Not found in W. Herbert has already entered the priesthood, but finds the experience of it irksome. Metre:

Unique. Rhymes irregular and very widely spaced, those of 1. 3-10 and 13-23 being the widest in Herbert.

SubJect :

The irritating restraints of righteousness only appeased by love.

Notes:

4. Lines and life; cf. The Banquet, III, 57, 1. 51.

5. Store $=$ amplest abundance. So The Pearl, II, 383, 1. 26. Dr. Grosart gives the amazing explanation, "As abounding in choice vanities as a store."

6. Shall I always be a petitioner, never a master? 


\section{THE COLLAR}

I sTRUCK the board, and cry'd, No more !

$$
\text { I will abroad. }
$$

What? Shall I ever sigh and pine?

My lines and life are free, free as the rode,

Loose as the winde, as large as store.

Shall I be still in suit?

Have I no harvest but a thorn

To let me bloud, and not restore

What I have lost with cordiall fruit?

Sure there was wine

Before my sighs did drie it. There was corn Before my tears did drown it.

Is the yeare onely lost to me?

Have I no bayes to crown it?

No flowers, no garlands gay? All blasted?

All wasted? 
18. The same turn in The QuIP, III, 33, 1. 7.

24. Of binding power, though really only a rope of sand.

26. $W$ ink $=$ intentionally shut the eyes. So MISERIE, II, 257, 1. 62, and Acts xvii, 30 .

29. Take away the scarecrows. Manufactured fears shall no longer stop my breaking away.

33-36. Dr. Grosart well refers to Parentalia, VIII, 1. 7-10:

Tandem prehensa comiter lacernuila Susurrat aure quispiam,

Haec fuerat olim potio Domini tui. Gusto proboque dolium.

35. Me thoughts: so ARtillerie, II, 361, 1. 2. 
Not so, my heart! But there is fruit,

And thou hast hands.

Recover all thy sigh-blown age

On double pleasures. Leave thy cold dispute 20 Of what is fit and not. Forsake thy cage,

\section{Thy rope of sands,}

Which pettie thoughts have made, and made to thee Good cable, to enforce and draw,

And be thy law,

While thou didst wink and wouldst not see.

Away! Take heed!

I will abroad.

Call in thy death's head there. Tie up thy fears.

He that forbears

To suit and serve his need

Deserves his load.

But as I rav'd and grew more fierce and wilde

At every word,

Me thoughts I heard one calling, Childe ! 35

And I reply'd, My Lord. 


\section{INTRODUCTORY :}

The grapes of Eshcol. Numbers xiii, 23.

DATE:

Not found in W. See notes on 1.4 and 9.

METRE:

Unique.

Subject:

We experience all that the Israelites did in the wilderness, except the welcome clusters at the journey's end. But no: instead of the refreshment which those who were under the Law from time to time obtained, we have continually the new wine of Christ's blood.

Notes:

4. Sev'n may be used merely as a round number. Yet if, as is probable, this poem was written somewhere near the middle of his Bemerton life, the time here indicated would fall before the death of King James, of Herbert's mother, and of those other friends lamented in Affuction, II, 343, 1. 31-36. This was Herbert's last period of secular employment. Whatever the special reference of this date may be, it places the poem late in his life. - "Vogue $=a$ free course with a full sail; and hence aire in line 5:" A. B. Grosart.

7. Numbers xxxiii, 10. 


\section{THE BUNCH OF GRAPES}

Joy, I did lock thee up, but some bad man Hath let thee out again;

And now, me thinks, I am where I began Sev'n yeares ago. One vogue and vein, One aire of thoughts usurps my brain. 5 I did toward Canaan draw, but now I am Brought back to the Red sea, the sea of shame. 
8. The course of thought in this stanza is not at once obvious. It is something like this: On account of rebellions, God did not permit the Israelites to reach an abiding city. But their story is our story. Nothing which has moved men widely is an individual affair ; each step in a divine transaction is typical and for all time. So God's justice to the Jews will be proved his justice to us.

9. It is in the isolation of Bemerton, his desert, far from London and Cambridge, that Herbert feels the hardship of the march toward Canaan, i. e. the priesthood. The sacred wine - his priestly work must be his comfort.

10. Spann'd=have journeys of the same span or length. 1 Corinthians x, 11.

24. Herbert gathers together the notable cases of grapes: the grapes of Eshcol, 1. 19; the vineyard of Noah, fruitful to his injury (Genesis ix, 20, and The Church Militant, III, 359, 1. 15); the winepress of Isaiah (Isaiah lxiii, 3); and Christ the true vine (John $\mathrm{xv}, 1)$.

28. Mark xiv, 24. 
For as the Jews of old by God's command

Travell'd and saw no town, 9

So now each Christian hath his journeys spann'd.

Their storie pennes and sets us down.

A single deed is small renown.

God's works are wide, and let in future times.

His ancient justice overflows our crimes.

Then have we too our guardian fires and clouds.

Our Scripture-dew drops fast.

We have our sands and serpents, tents and shrowds.

Alas! Our murmurings come not last.

But where's the cluster? Where's the taste

Of mine inheritance? Lord, if I must borrow, 20

Let me as well take up their joy as sorrow.

But can he want the grape who hath the wine?

I have their fruit and more.

Blessed be God, who prosper'd Noah's vine And made it bring forth grapes good store. 25 But much more him I must adore Who of the law's sowre juice sweet wine did make, Ev'n God himself being pressed for my sake. 
Date:

Not found in W.

Metre:

Unique.

SubJeCt:

"Oh that I knew where I might find him!" Job xxiii, 3.

Notes:

3. Psalm xlii, 3.

4. $P$ rove $=$ reach certainty and success.

6. The sphere is the skie of 1.5 , and the centre the earth, as in Prayer, II, 183, 1. 9.

8. The opposite of Psalm cxxxix, 8.

14. Simper $=$ change countenance, twinkle. In THE Church-Porch, II, 29, 1. 123, and Affliction, II, $343,1.44$, as here, a simper is the smile worn when one meets his superiors.

20. Genesis viii, 9. 


\section{THE SEARCH}

Whither, O, whither art thou fled,

My Lord, my Love?

My searches are my daily bread,

Yet never prove.

My knees pierce th' earth, mine eies the skie,

And yet the sphere

And centre both to me denie

That thou art there.

Yet can I mark how herbs below

Grow green and gay,

As if to meet thee they did know,

While I decay.

Yet can I mark how starres above

Simper and shine,

As having keyes unto thy love,

While poore I pine.

I sent a sigh to seek thee out,

Deep drawn in pain,

Wing'd like an arrow; but my scout

Returns in vain. 
25. Dost thou withhold thy visits because somewhere thou art making a new, good world, and abandoning the old bad.one?

29. Psalm lxxvii, 7-9.

33. Let not that, -i. e. thy will, - of all things, be what cuts me off from thee. The next three stanzas call upon God to exercise that will in Herbert's behalf. 35. Ring = fence, barrier.

36. Passe $=$ overcome, surmount them. 
I tun'd another (having store)

Into a grone,

Because the search was dumbe before;

But all was one.

Lord, dost thou some new fabrick mold, 25

Which favour winnes

And keeps thee present, leaving th' old

Unto their sinnes?

Where is my God? What hidden place

Conceals thee still?

What covert dare eclipse thy face?

Is it thy will?

$O$ let not that of any thing!

Let rather brasse,

Or steel, or mountains be thy ring,

And I will passe.

Thy will such an intrenching is

As passeth thought.

To it all strength, all subtilties

Are things of nought. 
41. As this stanza partially repeats the thought of the preceding, so the rhyme of that is partially repeated.

47. Charge $=$ burden.

52. Cf. Justice, III, 117, 1. 24.

55. Romans viii, 35.

58. Referring to 1.41.

59. Excels all else. Cf. Сhurch-Рorch, II, 37, 1. 187.

60. So Antiphon, II, 107, 1. 23. 
Thy will such a strange distance is

As that to it

East and West touch, the poles do kisse, And parallels meet.

Since then my grief must be as large

As is thy space,

Thy distance, from me; see my charge,

Lord, see my case.

O take these barres, these lengths away! Turn, and restore me.

Be not Almightie, let me say,

Against, but for me.

When thou dost turn and wilt be neare,

What edge so keen,

What point so piercing, can appeare

To come between?

For as thy absence doth excell

All distance known, So doth thy nearenesse bear the bell,

Making two one. 
INTRODUCTORY :

ASSURANCE $=$ The ground of confidence. Cf. Aaron, III, 11.

DAte:

Not found in W. $\mathrm{He}$ is failing in his work as a priest.

Metre:

Used also in Affliction, II, 247.

SUBJECT:

From suspicious thoughts about God's favor I take refuge in Himself.

Notes:

6. There is no poison so deadly as the inventions of distrust.

9-12. All this is the allegation of his spitefull thought.

In 1. 11 and elsewhere in this poem there seems to be allusion to the covenant of OBEDIENCE, II, 385 .

13. Can anything be worse than this? 


\section{ASSURANCE}

O SPITEFULL bitter thought!

Bitterly spitefull thought! Couldst thou invent So high a torture? Is such poyson bought?

Doubtlesse but in the way of punishment,

When wit contrives to meet with thee, 5 No such rank poyson can there be.

Thou said'st but even now

That all was not so fair as I conceiv'd

Betwixt my God and me: that I allow 9 And coin large hopes, but that I was deceiv'd; Either the league was broke or neare it, And that I had great cause to fear it.

And what to this? What more 13

Could poyson, if it had a tongue, expresse?

What is thy aim? Wouldst thou unlock the doore

To cold despairs and gnawing pensivenesse? Wouldst thou raise devils? I see, I know, I writ thy purpose long ago. 
22. If the ground of my confidence were myself and not thee, 1. 25.

24. The foes are inner foes, sins.

28. Does the league here and in 1.11 refer to the priesthood? Cf. Obedience, II, 387, 1. 32-35.

35. Psalm xxxi, 3; Mark xiii, 31.

38. This fancy that God is against thee, a fancy which merely hides thy own shame, - that thou art against God. Genesis iii, 7.

39-40. "Thou hast cast a bone of contention which has rebounded on thyself and chokes thee:" A. B. Grosart. Cf. The Country Parson, XXVIII: He that throws a stone at another hits himselfe. In a letter dated 1622, J. Howell, describing the former English alliance with the Netherlands, writes: "This was the Bone that Secretary Walsingham told Queen Elizabeth he would cast the King of Spain, that should last him twenty years and perhaps make his teeth shake in his head."

41, 42. To satisfy his own nature God went forth to man, and He will not fail to finish his work. John xiii, 1. 
But I will to my Father,

Who heard thee say it. O most gracious Lord, 20 If all the hope and comfort that I gather Were from my self, I had not half a word,

Not half a letter to oppose

What is objected by my foes.

But thou art my desert, 25

And in this league, which now my foes invade,

Thou art not onely to perform thy part,

But also mine; as when the league was made

Thou didst at once thy self indite,

And hold my hand while I did write.

Wherefore if thou canst fail,

Then can thy truth and I. But while rocks stand, And rivers stirre, thou canst not shrink or quail. Yea, when both rocks and all things shall disband, Then shalt thou be my rock and tower, 35 And make their ruine praise thy power.

Now foolish thought go on, Spin out thy thread and make thereof a coat

To hide thy shame; for thou hast cast a bone Which bounds on thee, and will not down thy throat.

What for it self love once began,

Now love and truth will end in man. 
Date:

Not found in W.

Metre:

Unique.

SUBJECT:

The stern exactions of Conscience stilled by Christ.

Notes:

5. Chatting = chattering.

6. All that I see or hear is distorted.

10. The rhyme there and sphere had already been used in Prayer, II, 183, 1. 11.

13-24. Not only does the blood of Christ, accepted in the Communion wine, cleanse us (my physick, l. 15) so that conscience can no longer accuse, but the love of Christ as a moral principle is sc at issue with the self-conscious calculations of the Law that it may be said to be a bill-hook or staff capable of turning the attack against conscience itself ( $m y$ sword, 1. 24). 


\section{CONSCIENCE}

Peace pratler, do not lowre!

Not a fair look but thou dost call it foul.

Not a sweet dish but thou dost call it sowre.

Musick to thee doth howl.

By listning to thy chatting fears

I have both lost mine eyes and eares.

Pratler, no more, I say!

My thoughts must work, but like a noiselesse sphere;

Harmonious peace must rock them all the day.

No room for pratlers there.

If thou persistest, I will tell thee

That I have physick to expell thee.

And the receit shall be

My Saviour's bloud. Whenever at his board

I do but taste it, straight it cleanseth me

And leaves thee not a word;

No, not a tooth or nail to scratch, And at my actions carp or catch.

Yet if thou talkest still,

Besides my physick know there's some for thee; Some wood and nails to make a staffe or bill

For those that trouble me.

The bloudie crosse of my deare Lord Is both my physick and my sword. 
Date:

Not found in W.

Metre:

Used also in The Agonie, III, 153.

SuBJECT:

What I have obtained after years of desire I am now powerless to use. With this poem compare the close of Love Unknown, III, 183, and of The Pilgrimage, III, 239.

Notes:

5,6 . These lines give some of the reasons which induced Herbert to accept the living of Bemerton from his great kinsman. He hoped through the influence of the neighboring Pembroke family at Wilton House to strengthen his work as a parish priest.

8. This deare end = the priesthood, the aim described in 1.3.

10. For myself, dear mother, I alwaies fear'd sickness more then death; because sickness hath made me. unable to perform those offices for which I came into the world: Herbert's letter, 1622.

13. Cf. Affliction, II, 341, 1. 27.

16. Cf. Gratefulnesse, III, 43, 1. 22.

18. I still retain a strong desire for thy work, embittering my feebleness. 


\section{THE CROSSE}

WhAT is this strange and uncouth thing?

To make me sigh, and seek, and faint, and die, Untill I had some place where I might sing,

And serve thee; and not onely I,

But all my wealth and familie might combine 5 To set thy honour up as our designe.

And then when after much delay,

Much wrastling, many a combate, this deare end,

So much desir'd, is giv'n, to take away

My power to serve thee! To unbend

All my abilities, my designes confound,

And lay my threatnings bleeding on the ground!

One ague dwelleth in my bones,

Another in my soul (the memorie

What I would do for thee if once my grones 15

Could be allow'd for harmonie).

I am in all a weak disabled thing,

Save in the sight thereof where strength doth sting. 
21. On $m e=$ against me. The edge is the means of wounding. Cf. Affliction, II, 343, 1. 33.

22. Psalm cii, 10. So Donne, Hymn to God in My Sickness, 1. 30:

"Be this my text, my sermon to mine own:

Therefore, that he may raise, the Lord throws down."

30. $A$ weed, as in Employment, II, 349, 1. 22, instead of such a flower as is described in The Flower, III, 307, 1. 23. At present he is in Paradise (III, 39), but suffers from lack of occupation. Cf. THE Country Parson, XXXII: Even in Paradise man had a calling, and how much more out of Paradise, when the evills which he is now subject unto may be prevented, or diverted by reasonable imployment.

36. My words = thy words made mine. 
Besides, things sort not to my will

Ev'n when my will doth studie thy renown. 20 Thou turnest th' edge of all things on me still,

Taking me up to throw me down.

So that ev'n when my hopes seem to be sped

I am to grief alive, to them as dead.

To have my aim, and yet to be

Farther from it then when I bent my bow;

To make my hopes my torture and the fee

Of all my woes another wo,

Is in the midst of delicates to need,

And ev'n in Paradise to be a weed.

Ah my deare Father, ease my smart!

These contrarieties crush me. These crosse actions

Doe winde a rope about, and cut my heart.

And yet since these thy contradictions

Are properly a crosse felt by thy sonne -

With but foure words, my words, Thy will be done. 


\section{THE PILGRIMAGE}

\section{INTRODUCTORY :}

Hebrews xi, 14. “The characteristic of Herbert's fancy is fruitfulness. The poetry, like the theology, of that age, put all learning into an abridgement. A course of lectures flowed into the rich essence of a single sermon. A month's seed bloomed in an ode. The 17th was the contradiction of the 19th century; the object being then to give the most thought in the smallest space, as now to sow the widest field with the frugallest corn. Herbert's Pilgrimage is an example. Written, probably, before Bunyan was born, - certainly while he was an infant, - it contains all the Progress of the Pilgrim in outline. We are shown the gloomy cave. of Desperation, the Rock of Pride, the Mead of Fancy, the Copse of Care, the Wild Heath where the traveller is robbed of his gold, and the gladsome Hill that promises a fair prospect, but only yields a lake of brackish water on the top. Such a composition would hardly escape the notice of that Spenser of the people, who afterwards gave breadth and animation and figures to the scene:" R. A. Willmott. 


\section{Date:}

Not found in W. I place this later than Love UNkNown because that contains no mention of coming death, and advances no farther than the fifth stanza of this. Bunyan's Pilgrim's Progress was published in 1678.

Metre:

Used only here, but it closely resembles that of Peace, II, 377.

\section{SUBJECT:}

Herbert's autobiography, such as he had given before in Affliction, II, 339, and in Love UNKNOwN, III, 179 ; and such as Tennyson gave in Merlin and the Gleam. 
Notes:

1. The hill=the priesthood, which, from a boy, he expected to attain.

4. Desperation = distrust of himself, as shown in THE Priesthood, II, 373.

5. At one time he doubts whether he is fit for the priesthood; at another whether the priesthood is fit for a man of his high breeding.

7. He was Reader in Rhetoric at Trinity College, Orator of the University, and had already acquired a name in poetry and fine letters.

10. Life was passing.

11. Care's cops = bewildering woods. This and the following stanza refer to the period which I have called The Crisis, and particularly to the experiences described in Vanitie, II, 357, and Frailtie, II, 359.

17. A play on the double meaning of $A n g e l l=a$ coin worth ten shillings, and a heavenly guardian. In the latter sense it may refer to his marriage, whish immediately preceded his taking orders. The work of a friend in saving Herbert is also alluded to in Love UnkNown, III, 181, 1. 43, and possibly in Peace, II, 379, 1. 19. 


\section{THE PILGRIMAGE}

I TRAVELL'D on, seeing the hill where lay

My expectation.

A long it was and weary way.

The gloomy cave of Desperation

I left on th' one, and on the other side

The rock of Pride.

And so I came to phansie's medow strow'd

With many a flower.

Fain would I here have made abode,

But I was quicken'd by my houre. 10

So to care's cops I came, and there got through

With much ado.

That led me to the wilde of passion, which

Some call the wold;

A wasted place, but sometimes rich. 15

Here I was robb'd of all my gold

Save one good Angell, which a friend had ti'd

Close to my side. 
19. The priesthood at Bemerton, which he found disappointing ; cf. Love Unknown, III, 181, 183, 1. 50-53, and The Crosse, III, 233, 1. 19-31.

23. His parish life was stagnant and tasteless.

28. It had not proved what he had imagined in THE Call, III, 9, 1. 2.

31. The heavenly priesthood.

33. Cf. The Discharge, III, 189, 1. 38-40.

36. A chair = the sedan-chair, a noble mode of conveyance, which was being introduced into England in Herbert's later years. Cf. Montification, II,261, 1. 29. 
At length I got unto the gladsome hill,

Where lay my hope,

Where lay my heart. And climbing still, When I had gain'd the brow and top,

A lake of brackish waters on the ground Was all I found.

With that abash'd and struck with many a sting Of swarming fears,

I fell and cry'd, Alas my King!

Can both the way and end be tears?

Yet taking heart I rose, and then perceiv'd

I was deceiv'd;

My hill was further. So I flung away, Yet heard a crie

Just as I went, None goes that way And lives! If that be all, said I,

After so foul a journey death is fair,

And but a chair. 



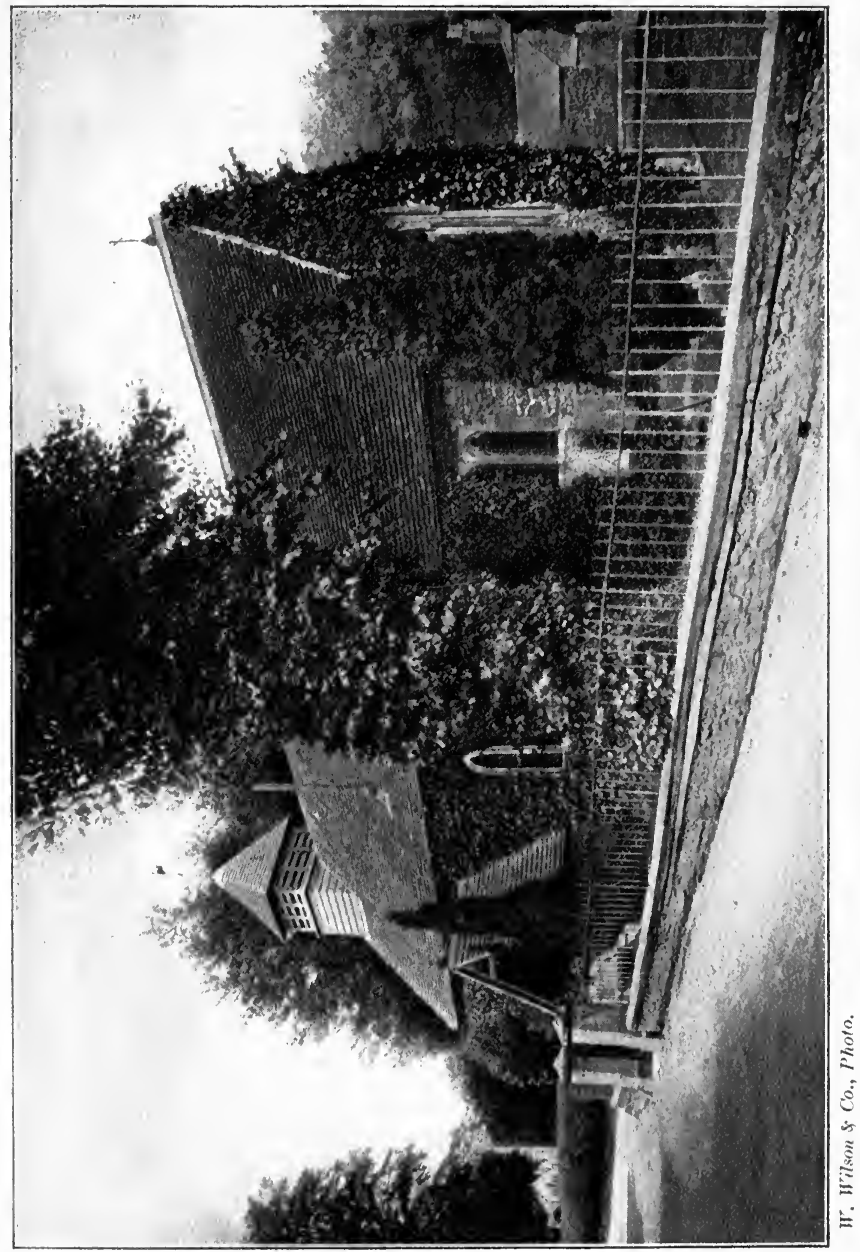





\section{X}

\section{SUFFERING}




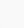




\section{PREFACE}

T $\mathrm{N}$ one of the closing poems of the preceding 1 Group, The Crosse, Herbert complains that ill health is crippling his powers and rendering him unfit for work. Undoubtedly illness had much to do with the restlessness and despondency which the poems of Group IX describe. The fear of it had long been in his mind, and was expressed as early as 1622 in that letter to his mother from which I have already quoted. During the Crisis period it comes out in The Priesthood as another reason for hesitation when he is just coming to a decision.

\section{Should I presume}

To wear thy habit, the severe attire

My slender compositions might consume.

I am both foul and brittle.

Herbert's constitution was naturally frail. Speaking of his sicknesses in EASTER Wings he says, My tender age in sorrow did beginne. In the letter of 1610 to his mother he mentions my late ague. In 1617 he writes his stepfather: You know I was sick last vacation, neither am I yet recovered, so that I am fain ever and anon to buy somewhat tending towards my health. Walton says that "He had often de- 
sign'd to leave the University and decline all Study, which he thought did impair his health, for he had a body apt to a Consumption and to Fevers and other infirmities." Later, Walton writes: "About the year $1629 \mathrm{Mr}$. Herbert was seiz'd with a sharp Quotidian Ague. He became his own Physitian and cur'd himself of his Ague by forbearing Drink, and not eating any Meat, no not Mutton nor a Hen or Pidgeon, unless they were salted. And by such a constant Dyet he remov'd his Ague, but with inconveniencies that were worse; for he brought upon himself a disposition to Rheumes and other weaknesses and a supposed Consumption."

Probably this severe illness occurred somewhat earlier in the Crisis period than Walton here states; for Herbert married in March, 1629, and Walton in another passage says that before "he declar'd his resolution both to marry and to enter into the Sacred Orders of Priesthood ... his health was apparently improv'd to a good degree of strength and chearfulness." In any case, it was but a few years later that he undertook his work at Bemerton with consumption well under way. The seeds of it were provided by his natural constitution; its development was advanced by the physical and mental experiences of the Crisis; and its end was assured by his taking up a new and anxious form of life under circumstances where introspection and depression were inevitable. 
There is no sharp dividing line parting this Group of poems from the preceding. They are separated rather by the varying degrees of emphasis laid on motives common to the two. Throughout them both ring notes of disappointment over the priesthood, despondency, rebellion, dulness, self-reproach, penitence, mental perplexity, bodily pain, fear of God's alienation, and the bitterness of lifelong purposes coming to an end. This sad material I have tried to set in order. The poems which are chiefly dominated by the earlier emotions mentioned, I place in Group IX; those ruled by the later, in Group X. In the former, the mental side of his distress is uppermost, - his intellectual discontent. In the second, physical suffering declares itself, which still, after the manner of the love-poets, he attributes to some possible fault in himself and negligence on the part of the great Friend.

It is noticeable how comparatively slight a place in these laments Herbert gives to regrets for the broken priesthood. While it seems certain that two clear purposes ran together throughout Herbert's life, the purpose to be a priest and that to be a poet, the former remained only a purpose until twelve thirteenths of his short life were gone. The latter passed out of the stage of resolution and became a diligently prosecuted reality as early as 1610 . That his poetic work is to end he mourns in Grief, Dulnesse, and The Forerunners, and to it he 
alludes at the close of The Flower. But there is little direct mention of the cessation of his priestly work. I think this must be explained by the highly individualistic conception of religion which he held. * Repeatedly I have pointed out how his holy aspirations confine themselves to drawing close the ties between God and his own soul. Possibly he may have regarded these essentially personal relations as those best fitted for expression in poetry. At any . rate, it is of his own salvation that he regularly speaks. He will be God's child; will love Him and be loved. The desire to sanctify himself for the sake of others rarely appears. We cannot comprehend a great nature unless we are willing to observe its limitations. Herbert shared those of his age. Its noblest work was to take the single soul and set it before God. Piety as personal allegiance was its special Gospel, a partial Gospel no doubt, as are the thoughts about religion of each succeeding age. But partial as it was, it was a real and weighty part, and it made a permanent contribution to the spiritual resources of our race. His priesthood Herbert accordingly thought of as primarily the dedication of himself to God. When it appeared that God wanted him not here, but above, he experienced few regrets over priestly work left undone. Regrets he has. Sighs and groans abound. But they are those of the lover conscious of his own lack of desert, and uncertain whether at last he may find favor in the loved one's sight. 
On the other hand, Herbert has for more than twenty years been studious of poetry. In it he has been conscious of something more like public ser- vice than even the priesthood yielded. The latter has been principally a means of effecting his own salvation; the former, of obeying the laws of beauty, and counteracting certain evil tendencies of his time. To its delicate demands he still steadily holds himself. These closing cries of pain are guarded, and given as beautiful a form as ever The Euixer or Mortification had in the proud Cambridge days. I find no falling off, no slovenliness, in all this preoccupied period. THE Flower is one of his most subtly beautiful pieces, though declaring itself to be very late. And The Forerunners, Vertue, Life, and The Glance, which I believe must stand in the Death Group, stand also in the very front rank of Herbert's performance.

I have already indicated the scheme of my arrangement. It follows the gradually increasing prominence of the consciousness of bodily ill. There runs through the early poems of the Group - Grieve Not, Confession, The Storm, ComPLAINING - a fear that God has withdrawn Himself. This changes in the Afrlictions, Sighs AND Grones, and Longing, to a sense of physical pain, a pain which he believes, though sent by God, is sent in love. In The Glimpse, A Parodie, JoSEPH'S COAT, and JESU, there springs up a kind of 


\section{PREFACE}

tender playfulness between him, the sufferer, and the Friend who brings the bitter gift. And in one of the sweet intervals of suffering, reported in The Flower, full joy and peace are felt in the presence of the loved one. 
SUFFERING 
INTRODUCTORY :

In contrast with Revelation $\mathbf{x}, 9$, God's dealings with us, if bitter at first, are sweet afterwards. A poem similarly paradoxical is CLASPING of HANDs, III, 37.

Date:

Not found in W.

Metre:

Unique.

SUBJECT :

Contradictions involved in the life of love. 2 Corinthians iv, 8-10, and vi, 10. 


\section{BITTER-SWEET}

Aн my deare angrie Lord, Since thou dost love, yet strike, Cast down, yet help afford, Sure I will do the like.

I will complain, yet praise;

I will bewail, approve; And all my sowre-sweet dayes

I will lament, and love. 
INTRODUCTORY :

Another poem with this title is given, III, 117. Date:

Not found in W.

\section{Metre:}

Unique, but differs only in rhyming system from The Jews, III, 109. Equally wide rhymes are found in Ungratefulnesse, II, 243; ComplainING, III, 267; Sighs AND Grones, III, 277.

SubJECT:

God's ways are incomprehensible, made so by the incomprehensibility of our own. The first stanza describes God's ways, the second ours. As God's are always connected, the lines are inwoven (as in A Wreath, II, 319). But ours are essentially disjointed and contradictory. Ezekiel xviii, 25, 29.

Notes:

7. Thou givest me a fitting return for my own waywardness. The former four paradoxes seemed, these four are, insoluble.

9. Mean=intend, aim at. So The Church-Porch, II, 53, 1. 334. For the thought, cf. Love UNKNown, III, 183, 1. 59; The Method, III, 197, 1. 15.

11. Cf. Affliction, II, 343, 1. 48, and The Answer, II, 351, 1. 7 . 


\section{JUSTICE}

I CANNoT skill of these thy wayes.

Lord, thou didst make me, yet thou woundest me;

Lord, thou dost wound me, yet thou dost relieve me;

Lord, thou relievest, yet I die by thee;

Lord, thou dost kill me, yet thou dost reprieve me.

But when I mark my life and praise, Thy justice me most fitly payes;

For I do praise thee, yet I praise thee not;

$M y$ prayers mean thee, yet my prayers stray;

I would do well, yet sinne the hand hath got; 10 My soul doth love thee, yet it loves delay.

I cannot skill of these my wayes. 


\section{GRIEVE NOT THE HOLY SPIRIT}

INTRODUCTORY :

Cf. Vaughan's Jesus Weeping. One other poem Herbert has entitled with a verse of Scripture, Our Life is Hid with Christ in Grod, II, 283.

\section{DATE:}

Not found in W.

Metre:

Unique.

SubJect :

That God is grieved over my sins shall make me grieve the more. Cf. Affliction, III, 271, 1. 15. The Holy Spirit is addressed in the first stanza, himself in the next three, God in the last two.

\section{Notes :}

1. Dove, the emblem of the Holy Spirit, as in WhITSUNDAY, II, 157, 1. 1.

5. I, emphatic, in contrast with God. - In three other passages in which a worm is mentioned (THE Сhurch-Porch, II, 55, 1. 339; Peace, II, 377, 1. 17; Church-Rents and Schismes, III, 105, 1. 3) it appears as a destructive creature. Here and in The Church-Porch, II, 45, 1. 261, and in Sighs AND Grones, III, $277,1.5$, it is a type of insignifcance. Psalm xxii, 6.

10. Tears being impossible in death (DEATH, II, 263, 1. 12), as long as you weep you may live. Or if, my heart, you do separate from the body, then melt 
GRIEVE NOT THE HOLY SPIRIT, \&C.

(EPHESIANS VI, 30)

AND art thou grieved, sweet and sacred Dove,

When I am sowre

And crosse thy love?

Grieved for me? The God of strength and power Griev'd for a worm, which when I tread 5 I passe away and leave it dead?

Then weep mine eyes, the God of love doth grieve. Weep foolish heart,

And weeping live.

For death is drie as dust. Yet if ye part, 10

End as the night whose sable hue Your sinnes expresse: melt into dew. 


\section{GRIEVE NOT THE HOLY SPIRIT}

into such drops as mark the close of night. The same allusion in Church-Rents and Schismes, III, 107, 1. 30.

15. As punctuated here and in ed. 1633 this must mean, "Give mirth no answer."

19. The lute was the favorite musical instrument of Herbert's day, chiefly employed, like our guitar, to furnish accompaniment to song. It was pearshaped, with a rounded back and many strings. In The Temple Herbert names it four times and alludes to it as many more.

23. So The Church-Floore, III, 167, 1. 15.

24. Bowels=pity, sympathy.

28. If water never ceases to run from a spring, and run not merely to relieve thirst, what shall I do who have much greater need to cleanse myself by continual flowing? Deniall, II, 299, 1. 27, has Deferre no time.

30. I am no Crystall = not clear and free from stain.

31. Still=always. 
When sawcie mirth shall knock or call at doore,

Cry out, Get hence,

Or cry no more.

Almightie God doth grieve, he puts on sense.

I sinne not to my grief alone,

But to my God's too; he doth grone.

Oh take thy lute, and tune it to a strain Which may with thee

All day complain.

There can no discord but in ceasing be.

Marbles can weep; and surely strings

More bowels have then such hard things.

Lord, ' $I$ adjudge my self to tears and grief, 25 Ev'n endlesse tears

Without relief.

If a cleare spring for me no time forbears, But runnes although $I$ be not drie, I am no Crystall, what shall I ?

Yet if I wail not still, since still to wail Nature denies, And flesh would fail

If my deserts were masters of mine eyes, $\quad 34$ Lord, pardon, for thy sonne makes good My want of tears with store of bloud. 
DAte:

Not found in W.

Metre:

Unique.

SUBJECT:

No peace in secret sin.

Notes:

5. Till=a compartment within a drawer, usually for money. Cf. Ungratefulnesse, II, 245, 1. 29.

8. Work and winde. Herbert uses this combination twice elsewhere, Jordan, II, 93, 1. 13, and The WorLD, II, 227, 1. 13, and characteristically modified in Businesse, III, 139, 1. 9.

12. A curious parallel in Jacula Prudentum: Wealth is like rheum; it falls on the weakest part. 


\section{CONFESSION}

O what a cunning guest

Is this same grief! Within my heart I made

Closets; and in them many a chest;

And like a master in my trade,

In those chests, boxes; in each box, a till: 5

Yet grief knows all, and enters when he will.

No scrue, no piercer can

Into a piece of timber work and winde

As God's afflictions into man,

When he a torture hath design'd.

They are too subtill for the subt'llest hearts, And fall, like rheumes, upon the tendrest parts. 
14. The mole is again mentioned in Grace, II, 311, 1. 13.

15. Cf. The Agonie, III, 153, 1. 12.

17. Keyes. 'This is Herbert's regular pronunciation (Easter, II, 153, 1. 11; H. Communion, II, 195, 1. 21). He may seem to give it our sound in The Pearl, II, 381, 1. 9, and Longing, III, 285, 1. 48, but probably does not.

19. All his house knowes that there is no help for a fault done but confession: Country Parson, $\mathbf{X}$.

22. This rhyme occurs again in Content, II, 353, 1. 20. 29. Them =day and diamond.

30. $T o=$ compared to. 
We are the earth, and they,

Like moles within us, heave, and cast about;

And till they foot and clutch their prey 15

They never cool, much lesse give out.

No smith can make such locks but they have keyes.

Closets are halls to them; and hearts, high-wayes.

Onely an open breast

Doth shut them out, so that they cannot enter. 20

Or, if they enter, cannot rest

But quickly seek some new adventure.

Smooth open hearts no fastning have, but fiction

Doth give a hold and handle to affliction.

Wherefore my faults and sinnes,

Lord, I acknowledge. Take thy plagues away.

For since confession pardon winnes,

I challenge here the brightest day,

The clearest diamond. Let them do their best, They shall be thick and cloudie to my breast. 30 
Date:

The natural place for this poem seems to be here, because it pictures distresses of the inner life, and is not included in W. But it may have been written shortly after Artillerie, II, 361, and The Starre, II, 365, and still not have been copied into W.

Metre:

Used also in EAster, II, 153.

SUBJECT:

The calm of God's abode invaded by human supplication.

Notes:

6. Object=objectify, set before their faces.

7. Storms $=$ meteor showers, like those which give occasion to the poems, Artillerie, II, 361, and The Starre, II, 365. The reason for mentioning them here, however, is not very plain. Perhaps having spoken in the previous verse of tempests of wind and rain as storms here below, his thought passes on to the celestial storms as more nearly resembling those with which he proposes to assail high heaven.

12. So reversed thunder of Prayer, II, 181, 1. 6.

13. The musick here may be that musick in the spheres mentioned in Artillerie, II, 361, 1. 9, or the tunes mentioned in Gratefulnesse, III, 43, 1. 22, or most probably the acclamations of Revelation v, 13. 


\section{THE STORM}

IF as the windes and waters here below

Do flie and flow,

My sighs and tears as busie were above,

Sure they would move

And much affect thee, as tempestuous times 5 Amaze poore mortals and object their crimes.

Starres have their storms, ev'n in a high degree, As well as we.

A throbbing conscience spurred by remorse $\quad 9$

Hath a strange force.

It quits the earth, and mounting more and more, Dares to assault thee and besiege thy doore.

There it stands knocking, to thy musick's wrong, And drowns the song.

Glorie and honour are set by till it

An answer get.

Poets have wrong'd poore storms. Such dayes are best;

They purge the aire without, within the breast. 
Date:

Not found in W.

Metre:

Unique.

SUBJECT:

The Christian Temple, in contrast with the Jewish, is built within the heart, and has human aspirations for its liturgy. 1 Corinthians iii, 16; 2 Corinthians vi, 16; Revelation xxi, 22; John ii, 21. For other places where Herbert uses the word temple, see note on The Windows, III, 15, 1. 3.

Notes:

9. Habakkuk i, 3, 4.

17. 1 Kings vii, 23, 51; Acts vii, 47, 48.

21. Quick=living in contrast with dead, 1. 20. The thought occurs again in GRATEFULNESSE, III, 43, 1. 19. 


\section{SION}

LoRD, with what glorie wast thou serv'd of old, When Solomon's temple stood and flourished!

Where most things were of purest gold.

The wood was all embellished With flowers and carvings, mysticall and rare. 5 All show'd the builder's, crav'd the seer's care.

Yet all this glorie, all this pomp and state Did not affect thee much, was not thy aim;

Something there was that sow'd debate.

Wherefore thou quitt'st thy ancient claim, 10 And now thy Architecture meets with sinne; For all thy frame and fabrick is within.

There thou art struggling with a peevish heart, Which sometimes crosseth thee, thou sometimes it.

The fight is hard on either part.

Great God doth fight, he doth submit. All Solomon's sea of brasse and world of stone Is not so deare to thee as one good grone.

And truly brasse and stones are heavie things, Tombes for the dead, not temples fit for thee. 20 But grones are quick and full of wings, And all their motions upward be. And ever as they mount, like larks they sing. The note is sad, yet musick for a king. 
Date:

Not found in W.

Metre:

Unique. In each pair of verses the last lines rhyme together, while the third line of each stanza is broken in the middle.

SUBJECT :

Why so severe,- great as thou art and I so small? Notes:

3. So Submission, III, 205, 1. 1, and 1 Corinthians i, 24.

5. So in Deniall, II, 299, 1. 16.

7. The deed and storie $=$ all that has ever been done and said, corresponding with power and wisdome of 1.3.

13. Shall I have but a single attribute, grief, corresponding to thine only one, justice?

16. Feeble and brief as $I$ am, make me less so or more. So Grace, II, 311, 1. 22. The rhyming of the stanza expresses these alternatives. 


\section{COMPLAINING}

Do not beguile my heart,

Because thou art

My power and wisdome. Put me not to shame,

Because I am

Thy clay that weeps, thy dust that calls.

Thou art the Lord of glorie.

The deed and storie

Are both thy due. But I a silly flie,

That live or die

According as the weather falls.

Art thou all justice, Lord?

Shows not thy word

More attributes? Am I all throat or eye,

To weep or crie?

Have I no parts but those of grief? 15

Let not thy wrathfull power

Afflict my houre,

My inch of life. Or let thy gracious power

Contract my houre,

That I may climbe and finde relief. 20 
INTRODUCTORY :

Besides the poems which follow, two others with this title are given, II, 247 and 339.

Date:

Not found in W.

Metre:

Unique.

SúBJECT:

The same as that of The Thanksgiving, II, 287, the impossibility of matching Christ's sufferings with our own. Only the turn is added here: Why, then, should I have these perpetual and useless griefs?

Notes:

5. 1 Corinthians $\mathrm{xv}, 31$. In partial payment of thy death, I die daily during a life as long as Methuselah's.

10. They would show a color less vivid than thy bloodstained sweat. Luke xxii, 44. Cf. Justice, III, 117, 1. 5 .

15. Imprest = earnest-money. From the French prêt $=$ ready. "Earnest-money was called prest-money, and to give a man such money was to imprest him:" Skeat. 


\section{AFFLICTION}

KiLl me not ev'ry day,

Thou Lord of life; since thy one death for me

Is more then all my deaths can be,

Though $I$ in broken pay

Die over each houre of Methusalem's stay. $\quad 5$

If all men's tears were let

Into one common sewer, sea, and brine,

What were they all compar'd to thine?

Wherein if they were set, 9

They would discolour thy most bloudy sweat.

Thou art my grief alone, Thou Lord, conceal it not. And as thou art All my delight, so all my smart. Thy crosse took up in one, By way of imprest, all my future mone. $\quad 15$ 
Date:

Not found in W.

Metre:

Unique.

SuBJect :

Fellowship of Christ in our sufferings. Cf. Grieve Not, III, 255.

Notes:

7. Job xxxiii, 4.

8. $M y$ tallies $=$ my measure, how much breath I can spare.

9. What's then behinde?= what is there left ?

10. Referring to the popular belief that strength is impaired by sighing. So H. Communion, II, 197, 1. 31, L'Evvoy, III, 381, 1. 14, and Shakespeare, Hamlet, iv, 7: "Like a spendthrift sigh that hurts by easing."

17. Those who bemoan thy sufferings on the cross disparage what thou art doing for us now; for thou diest daily. 1 Corinthians xv, 31. 


\section{AFFLICTION}

My heart did heave, and there came forth, $O$ God!

By that I knew that thou wast in the grief,

To guide and govern it to my relief,

Making a scepter of the rod.

Hadst thou not had thy part,

Sure the unruly sigh had broke my heart.

But since thy breath gave me both life and shape, Thou knowst my tallies; and when there's assign'd So much breath to a sigh, what's then behinde?

Or if some yeares with it escape,

The sigh then onely is

A gale to bring me sooner to my blisse.

Thy life on earth was grief, and thou art still Constant unto it, making it to be A point of honour now to grieve in me,

And in thy members suffer ill.

They who lament one crosse,

Thou dying dayly, praise thee to thy losse. 
INTRODUCTORY :

In W. this poem is entitled Tentation.

Date:

Not found in W. Possibly 1. 25-28 allude to his being in the priesthood.

Metre:

Unique.

SuBJECT:

"Unite my heart to fear thy name:" Psalm lxxxvi, 11.

Notes:

3. Psalm xxxi, 12.

4. Psalm lxxi, 7.

9. Scatter'd. My thoughts sprinkle my heart with piercing pains, as watering-pots do flowers with life-giving drops. 


\section{AFFLICTION}

Broken in pieces all asunder,

Lord, hunt me not,

A thing forgot,

Once a poore creature, now a wonder,

A wonder tortur'd in the space

Betwixt this world and that of grace.

My thoughts are all a case of knives,

Wounding my heart

With scatter'd smart,

As watring pots give flowers their lives. 10 Nothing their furie can controll While they do wound and prick my soul. 
13. All my attendants = the many physical functions which wait upon my life. He rightly connects his melancholy with bodily disturbance.

15. Before my very face.

18. Contend with one another.

25. As described in 1. 13.

30. And - what is better still - reach thee. 
All my attendants are at strife,

Quitting their place

Unto my face.

Nothing performs the task of life.

The elements are let loose to fight,

And while I live trie out their right.

Oh help, my God! Let not their plot

Kill them and me,

And also thee,

Who art my life. Dissolve the knot,

As the sunne scatters by his light

All the rebellions of the night.

Then shall those powers which work for grief Enter thy pay,

And day by day

Labour thy praise and my relief;

With care and courage building me, Till I reach heav'n, and much more thee. 
Date:

Not found in W. Is thy steward of 1.8 a priest? Metre:

Unique. Equally wide rhymes are found in UNGRATEFulness, II, 243, in Justice, III, 253, and. in Complaining, III, 267.

SubJect :

An appeal for mercy on grounds of insignificance. Notes:

9. Stock may mean tree trunk, as in Grace, II, 311, 1. 1. But more probably it has its agricultural meaning, of cattle on a farm. 


\section{SIGHS AND GRONES}

O Do not use me

After my sinnes! Look not on my desert,

But on thy glorie! Then thou wilt reform And not refuse me; for thou onely art

The mightie God, but I a sillie worm. 5

O do not bruise me!

O do not urge me!

For what account can thy ill steward make?

I have abus'd thy stock, destroy'd thy woods, Suckt all thy magazens. My head did ake, 10

Till it found out how to consume thy goods.

$O$ do not scourge me! 
14. Exodus x, 22.

16. Sow'd fig-leaves. Genesis iii, 7.

17. Cf. The Priesthood, II, 373, 1. 11.

20. Turn' $d=$ "up-turned, that the dregs may be drunk. The word full shows this is the allusion:" A. B. Grosart. But there is also a recollection of Revelation xvi, 1.

28. Cordiall and Corrosive $=$ that which renews the life or wastes it away. So Shakespeare: "Care is no cure, but rather corrosive:" 1 Henry VI, iii, 3.

29. The bitter box=that which contains death, judgment, the rod, the corrosive. 
O do not blinde me!

I have deserv'd that an Egyptian night Should thicken all my powers, because my lust Hath still sow'd fig-leaves to exclude thy light. 16 But I am frailtie, and already dust.

$O$ do not grinde me!

O do not fill me

With the turn'd viall of thy bitter wrath!

For thou hast other vessels full of bloud,

A part whereof my Saviour empti'd hath, Ev'n unto death. Since he di'd for my good, O do not kill me!

But $\mathrm{O}$ reprieve me!

For thou hast life and death at thy command.

Thou art both Judge and Saviour, feast and rod,

Cordiall and Corrosive. Put not thy hand

Into the bitter box, but $\mathrm{O}$ my God,

My God, relieve me! 30 
INTRODUCTORY :

Set to music by Henry Purcell (1658-1695) in the Treasury of Music.

Date:

Not found in W.

Metre:

Unique.

SubJeCt :

The plan of the poem is to have no plan, but to be only a succession of disjointed cries, lamenting absence. The poem bears throughout a general resemblance to Psalm cii.

Notes:

9. Genesis iii, 17. 


\section{SUFFERING}

\section{LONGING}

WITH sick and famisht eyes, With doubling knees and weary bones,

To thee my cries,

To thee my grones,

To thee my sighs, my tears ascend.

No end?

My throat, my soul is hoarse.

My heart is wither'd like a ground

Which thou dost curse.

My thoughts turn round

And make me giddie. Lord, I fall, Yet call.

From thee all pitie flows.

Mothers are kinde because thou art, And dost dispose

To them a part.

Their infants them; and they suck thee More free. 
21. Psalm xxxi, 2.

26. Isaiah xlviii, 10. A furnace is also mentioned in Love Unknown, III, 181, 1. 26.

35. Psalm xciv, 9. Cf. Deniall, II, 297, 1. 14.

41. So in The Temper, II, 317, 1. 14, derived from Genesis ii, 7. 
Bowels of pitie, heare!

Lord of my soul, love of my minde,

Bow down thine eare!

Let not the winde

Scatter my words, and in the same

Thy name!

Look on my sorrows round!

Mark well my furnace! $O$ what flames,

What heats abound!

What griefs, what shames!

Consider, Lord! Lord, bow thine eare And heare!

Lord Jesu, thou didst bow

Thy dying head upon the tree;

$\mathrm{O}$ be not now

More dead to me!

Lord heare! Shall he that made the eare,

Behold, thy dust doth stirre,

It moves, it creeps, it aims at thee.

Wilt thou deferre

To succour me,

Thy pile of dust, wherein each crumme Sayes, Come? 
45-48. To things hast thou given free rein, locking thyself from all appeal against their course? So in The Country Parson, XXXIV: Those that he findes in the peaceable state, he adviseth to be very vigilant and not to let go the raines as soon as the horse goes easie. 49-52. In the divine order of the world, thought of as a kind of book of contracts which assigns to each thing its own procedure, the appealing look of a humble soul has been known to intervene. So Prayer, II, 181, 1. 7.

53. Cf. Providence, III, 93, 1. 133. The figure of life as a banquet with human beings as the guests was first brought forward by Lucretius, Bk. III, 938:

"Cur non ut plenus vitae conviva recedis Aequo animoque capis securam, stulte, quietem?" 
To thee help appertains.

Hast thou left all things to their course,

And laid the reins

Upon the horse?

Is all lockt? Hath a sinner's plea

No key?

Indeed the world's thy book,

Where all things have their lease assign'd;

Yet a meek look

Hath interlin'd.

Thy board is full, yet humble guests

Finde nests.

Thou tarriest, while I die

And fall to nothing. Thou dost reigne

And rule on high,

While I remain

In bitter grief. Yet am I stil'd

Thy childe.

Lord, didst thou leave thy throne

Not to relieve? How can it be

That thou art grown

Thus hard to me?

Were sinne alive, good cause there were 65 To bear. 


\section{LONGING}

67. Romans vi, 11.

69. $T h a t=\sin$.

70. These $=$ thy promises.

79. This iterated rhyme occurs also in $1.19,30$, and 36. 
But now both sinne is dead, And all thy promises live and bide. That wants his head; These speak and chide,

And in thy bosome poure my tears As theirs.

Lord JESu, heare my heart, Which hath been broken now so long,

That ev'ry part

Hath got a tongue!

Thy beggars grow; rid them away

To day.

My love, my sweetnesse, heare!

By these thy feet, at which my heart

Lies all the yeare,

Pluck out thy dart

And heal my troubled breast which cryes, Which dyes. 
Date:

Not found in W. See also 1. 30.

Metre:

Unique.

SUBJECT:

The tantalizing shortness of delight. In contrast to the full-ey'd love of The Grance, III, 331, 1. 20.

Notes:

8-10. Be not like winds and waves which quickly pass, though hardly blamable. Be rather like flowers which linger. Herbert usually views the flower as a type of fragility. See The Flower, III, 305.

15. So delight, which should refresh like water, makes me burn the more. 


\section{$\sqrt{\text { THE GLIMPSE }}$}

WhITHER away delight?

Thou cam'st but now; wilt thou so soon depart, And give me up to night?

For many weeks of lingring pain and smart

But one half houre of comfort for my heart? 5

Me thinks delight should have

More skill in musick and keep better time.

Wert thou a winde or wave,

They quickly go and come with lesser crime. $\quad 9$ Flowers look about, and die not in their prime.

Thy short abode and stay

Feeds not, but addes to the desire of meat.

Lime begg'd of old (they say)

A neighbour spring to cool his inward heat, Which by the spring's accesse grew much more great 
19. $T h i s=$ the probable brevity of thy stay.

23-25. Though fulness of delight is stored in the world to come, yet bliss-bringing glimpses need not too much disclose what rightly is kept sealed.

26-28. Do not think thy coming will interfere with work of mine. Grief and sin interfere. While thou art with me, I will keep my wheel in motion, making indeed thy stay seem short, 1. 11. If, however, stay is used, as frequently by Herbert (HoME, III, 325, $327,329,1.2,31,76)$, in the sense of be absent, then the meaning must be, " $\mathrm{My}$ wheel is of no importance, if only thy absence be short."

30. Court =a place of festival; and probably there is in Herbert's mind the farther suggestion, I shall be borne away from Bemerton to where I formerly was gay. 
In hope of thee my heart

Pickt here and there a crumme, and would not die;

But constant to his part

Whenas my fears foretold this, did replie,

A slender thread a gentle guest will tie.

Yet if the heart that wept

Must let thee go, return when it doth knock.

Although thy heap be kept

For future times, the droppings of the stock 24 May oft break forth, and never break the lock.

If I have more to spinne, The wheel shall go so that thy stay be short.

Thou knowst how grief and sinne

Disturb the work. Oे make me not their sport, Who by thy coming may be made a court! 30 


\section{INTRODUCTORY :}

In modern parody a serious poem is given a comic turn. The word originally did not imply this debasement. Any readjustment of a poem to a new meaning was a parody. Herbert has here taken one of Donne's exquisite love-songs and recast it in a religious sense. The subject of both poems is the same, - the pain of absence. The first half of Donne's poem, which Herbert copies most closely, runs thus:

“Soul's joy, now I am gone, And you alone Which cannot be, Since I must leave myself with thee, And carry thee with me Yet when unto our eyes

Absence denies

Each other's sight, And makes to us a constant night,

When others change to light;

$\mathrm{O}$, give no way to grief, But let relief

Of mutual love

This wonder to the vulgar prove,

Our bodies, not we, move."

Vaughan has parodied Herbert in more than twenty poems. 


\section{A PARODIE}

SouL's joy, when thou art gone,

And I alone -

Which cannot be,

Because thou dost abide with me

And I depend on thee -

Yet when thou dost suppresse

The cheerfulnesse

Of thy abode,

And in my powers not stirre abroad,

But leave me to my load;

$O$ what a damp and shade

Doth me invade!

No stormie night

Can so afflict or so affright

As thy eclipsed light. 
Date:

Not found in W. The date of Donne's poem is not known.

Metre:

Unique.

SuBJECT:

The pain of absence.

Notes:

8. Abode: see 1. 4.

20. The subject of say is Sinne. Cf. 1. 24, 29.

23. Cf. Assurance, III, 225, 1. 7. 
Ah Lord! Do not withdraw,

Lest want of aw

Make Sinne appeare,

And when thou dost but shine lesse cleare,

Say that thou art not here.

And then what life I have,

While Sinne doth rave,

And falsly boast

That I may seek but thou art lost,

Thou, and alone thou, know'st.

O what a deadly cold

Doth me infold!

I half beleeve

That Sinne sayes true. But while I grieve, Thou com'st and dost relieve. 
Date:

Not found in W.

Metre:

Unique.

SUBJECT:

Love is more effective than anger, and more worthy of thee.

Notes:

2. Jeremiah $\mathrm{x}, 24$.

12. Thy book=the H. Scriptures; see II, 187. 


\section{DISCIPLINE}

Throw away thy rod, Throw away thy wrath. O my Grod,

Take the gentle path.

For my heart's desire

Unto thine is bent.

I aspire

To a full consent.

Not a word or look

I affect to own,

But by book,

And thy book alone.

Though I fail, I weep.

Though $I$ halt in pace,

Yet I creep

To the throne of grace. 
22. I believe this is the only case where Herbert figures Love as a man.

27. Love brought Christ from heaven to earth. 
Then let wrath remove.

Love will do the deed:

For with love

Stonie hearts will bleed.

Love is swift of foot.

Love's a man of warre, And can shoot,

And can hit from farre.

Who can scape his bow?

That which wrought on thee,

Brought thee low,

Needs must work on me.

Throw away thy rod.

Though man frailties hath,

Thou art God.

Throw away thy wrath. 
INTRODUCTORY :

Joseph's coat was of many colors. Genesis xxxvii, 3 . In 1640 Thomas Fuller published a volume of sermons under the title of Joseph's Party-Coloured Coat.

Date:

Not found in W. Last two lines show that it is late. Metre:

Of seventeen sonnets, six - like this - are in the Shakespearian form.

SubJECT:

My grief is diverse. If single, it would destroy me; but since God gives it the changefulness of joy, I can even sing it.

Notes:

3. I would suggest that in the place of will we read right. There is no other case in Herbert of a pair of unrhymed lines in a sonnet.

6. $H i s=$ its.

8. Both = grief and smart, mental and physical distress. These, having seized my heart, would find means to carry off my body too, claiming both heart and body as theirs.

10. The race $=$ same as runne of 1.8 .

11. Herbert frequently abbreviates entice to tice; so The Forerunners, III, 319, 1. 21. 


\section{JOSEPH'S COAT}

Wounded I sing, tormented I indite, Thrown down I fall into a bed and rest.

Sorrow hath chang'd its note; such is his will

Who changeth all things as him pleaseth best. For well he knows if but one grief and smart 5 Among my many had his full career, Sure it would carrie with it ev'n my heart, And both would runne untill they found a biere To fetch the bodie, both being due to grief. But he hath spoil'd the race, and giv'n to anguish

One of Joye's coats, ticing it with relief

To linger in me, and together languish.

I live to shew his power who once did bring My joyes to weep, and now my griefs to sing. 
Date:

Not found in W.

Metre:

Unique.

SUBJECT:

Even when broken by calamity, my heart finds rest in Christ. The reverse of this theme is played with

- in The Altar, II, 121, where the unorganized but sacred parcels of the heart are seeking unity.

Notes:

9. Herbert rarely puns. With all his readiness to trace remote intellectual relations, he has no fondness for word-play as has Shakespeare and the majority of his contemporaries. Perhaps in this strange poem he has in mind Donne's Broken Heart, especially its last verse with the lines:

"I think my breast hath all

Those pieces still, though they be not unite."

Queen Mary said when dying that if her heart were opened, the word Calais would be found there. Browning refers to this saying of Queen Mary's when writing in De Gustibus:

"Open my heart and you will see Graved inside of it, "Italy.", 


\section{JESU}

JeSU is in my heart, his sacred name

Is deeply carved there. But th' other week

A great affliction broke the little frame, Ev'n all to pieces; which I went to seek.

And first $I$ found the corner where was $J, 5$

After where $E S$, and next where $U$ was graved.

When I had got these parcels, instantly

I sat me down to spell them; and perceived That to my broken heart he was I ease you, And to my whole is $J E S U . \quad 10$ 


\section{INTRODUCTORY :}

First sketches of this poem may be found in $\mathrm{RE}$ pentance, II, 305, and Employment, II, 347. Imitated by Vaughan in his Unprofitableness.

Date:

Not found in W. See also 1. 36.

Metre:

Unique.

SuBJECT:

In liability to change, my soul is like a flower. Job xiv, 2; Psalm ciii, 15; Isaiah xl, 6.

\section{Notes:}

3. Demean. Dr. Grosart thinks this equivalent to demesne or domain. I cannot join it to the context in this sense. May it not be another form of demeanor = bearing, or carriage? The passage would then signify: Flowers give positive pleasure by their own gay show, but a negative pleasure also when we recall the wintry time preceding. Cf. Psalm $\mathrm{xc}, 15$. So God's coming gives pleasure, through presence felt and absence remembered.

4. Coleridge, speaking of this whole poem as "delicious," calls attention to the beautiful succession of delayed syllables in the first half of this line. 


\section{THE FLOWER}

How fresh, O Lord, how sweet and clean Are thy returns! Ev'n as the flowers in spring,

To which, besides their own demean, The late-past frosts tributes of pleasure bring.

Grief melts away

Like snow in May,

As if there were no such cold thing.

Who would have thought my shrivel'd heart Could have recover'd greennesse? It was gone

Quite under ground, as flowers depart 10 To see their mother-root when they have blown;

Where they together

All the hard weather,

Dead to the world, keep house unknown.

These are thy wonders, Lord of power, 15 Killing and quickning, bringing down to hell

And up to heaven in an houre; Making a chiming of a passing-bell.

We say amisse,

This or that is;

Thy word is all, if we could spell. 
10. So in Parentalia, V, 13, describing his mother's garden after she has left it, he bids the flowers Cuncta ad radices redeant, tumulosque paternos.

16. So Wisdom xvi, 13.

18. Turning a funeral knell into a bridal peal.

21. Spell=interpret. So The Temper, II, 317, 1. 16, and A Dialogue-Antheme, III, 343, 1. 4.

25. Off'ring = uplifting itself toward.

28. Joining to produce tears.

34. The coldest experience on earth is warm compared with thy chilling frown. Same phrase in The SEARCH, III, 223, 1. 53.

36. In age. The poem was written late.

39. "The poem, The Flower, is especially affecting, and to me such a phrase as and relish versing expresses a sincerity, a reality which I would unwillingly exchange for the more dignified 'and once more love the muse:"' S. T. Coleridge in a letter to W. Collins.

45. Which=this knowledge.

48. Store, a favorite word with Herbert=abundance, superfluity. Proud through prosperity. Shakespeare in Sonnet LXIV pictures the land bordering the ocean as "Increasing store with loss and loss with store." 
$O$ that $I$ once past changing were,

Fast in thy Paradise, where no flower can wither!

Many a spring I shoot up fair,

Off'ring at heav'n, growing and groning thither;

Nor doth my flower

Want a spring-showre,

My sinnes and I joining together.

But while I grow in a straight line,

Still upwards bent, as if heav'n were mine own,

Thy anger comes, and I decline.

What frost to that? What pole is not the zone

Where all things burn,

When thou dost turn,

And the least frown of thine is shown?

And now in age $I$ bud again,

After so many deaths I live and write;

I once more smell the dew and rain,

And relish versing. $O$ my onely light,

It cannot be

That I am he

On whom thy tempests fell all night.

These are thy wonders, Lord of love,

To make us see we are but flowers that glide.

Which when we once can finde and prove,

Thou hast a garden for us where to bide.

Who would be more,

Swelling through store,

Forfeit their Paradise by their pride. 



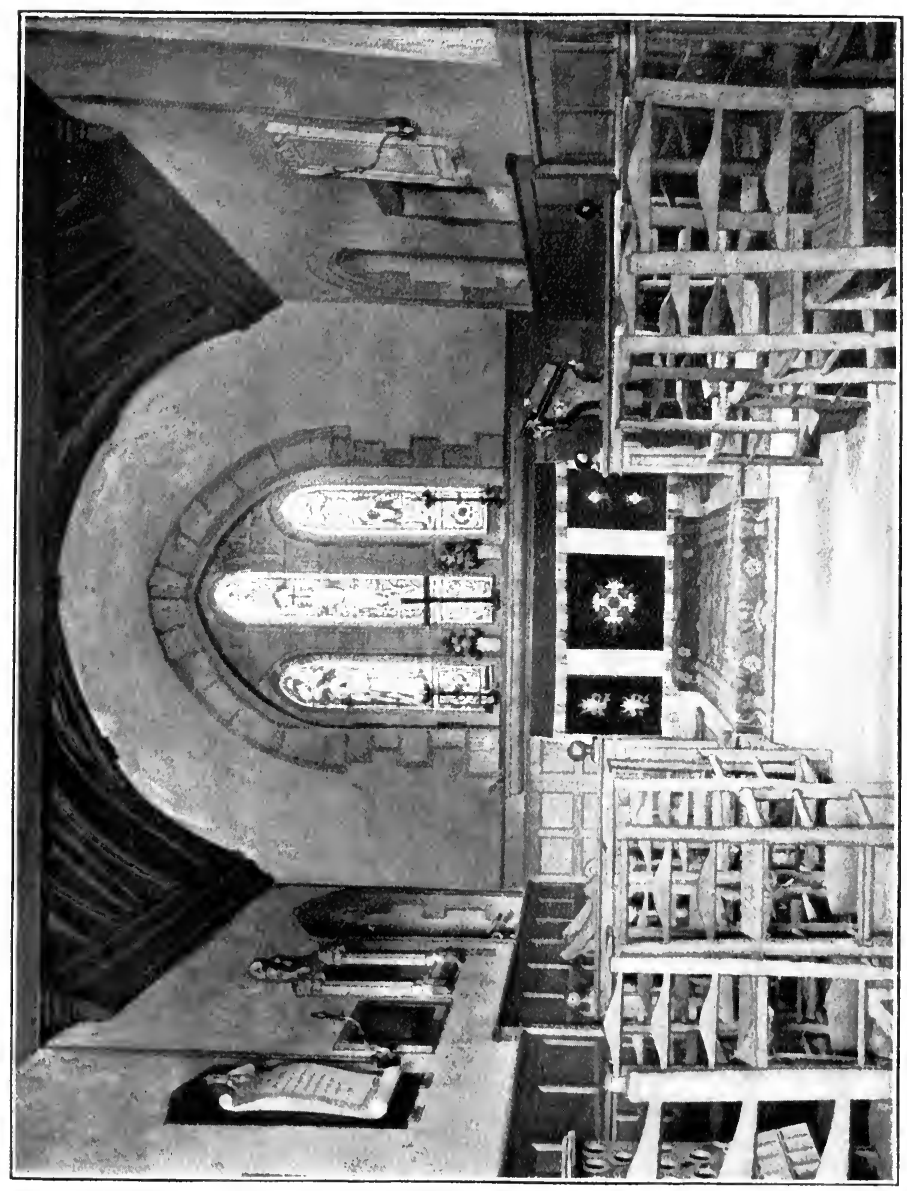





\section{XI}

\section{DEATH}





\section{PREFACE}

$\mathrm{T}$ the parish record of Bemerton appears this entry: "Mr. George Herbert Esq., Parson of Fuggleston and Bemerton, was buried 3 day of March 1632." This record is confirmed by Herbert's will, which was proved on March 12, 1632. As the new year then began on Lady Day, March 25, the year would be our 1633. This date is confirmed by Herbert's letter to Ferrar, inclosing his Notes on Valdesso, which bears date of September 29, 1632; and by the will of his niece, which was proved by Herbert in October, 1632. Herbert was instituted on April 26, 1630, so that the life at Bemerton covered almost exactly three years. Aubrey tells how Herbert "was buried (according to his own desire) with the singing service for the burial of the dead, by the singing men of Sarum." He was laid, according to Walton, "in his own Church under the Altar, and cover'd with a Gravestone without any inscription." He died without issue. His wife, whom Aubrey thought a strikingly handsome woman, a few years later married Sir Robert Cook, and by him had children.

Herbert had long notice of death. Consumption overcame him slowly, and allowed him to retain his mental powers to the last. Until within a few 
months of the end, he read Prayers each day in the little chapel opposite his house. And though a month before his death Mr. Duncon, sent by Ferrar, found him unable to sit up, his discourse was such, Mr. Duncon told Walton, "that after almost forty years it remained still fresh in his memory." The Sunday before he died he sang his own songs, accompanying himself as usual on the lute. According to Walton he died without pain, in his last hour speaking with his family and friend about religion, business, and the care of those he was to leave.

To this fact, that Herbert's long dying was a life in death, we owe the splendid series of his deathsongs. A few of those included in the preceding Group may possibly belong to the period of Crisis; but the great body of them, and probably all that appear in the present Group, spring from the last year or two of Herbert's life. As we have seen, every phase of his inner moods was interesting to him, and easily became a poetic subject out of which something beautiful might be fashioned. If because our distresses do not so readily put on a coat of joy, we sometimes hold it half a sin that Herbert should put in words the grief he feels, we should remember that he published none of his poems, and that in poetry he probably found one of his few defences against pain. Wounded $I$ sing; tormented I indite, he says. By objectifying his experiences he detaches himself from them. 
Donne in his Triple Fool had tried this palliative:

“As th' earth's inward narrow crooked lanes

Do purge sea-water's fretful salt away,

$I$ thought if I could draw my pains

Through rhyme's vexation, I should them allay.

Grief brought to numbers cannot be so fierce,

For he tames it that fetters it in verse."

I have thought it well to gather into a brief final Group Herbert's poems which refer to approaching death. How unlike they are to the clever verses written at Cambridge on the same subject! All the , poems of this Group have in them the note of reality, whether like The Forerunners and Life they mourn the cessation of his verse, like GrIEF and Home utter an anguished cry, like The Glance and The Dawning turn to the sweet originall joy of God's love, or like Vertue, Time, and A Dialogue-Antheme, sport with the impotence of death. In all of them there is veritable experience carried up into well-ordered beauty. The methods of Herbert's Life did not forsake him in the leaving of it. 



\section{DEATH}




\section{INTRODUCTORY :}

"Though God had magnified him with extraordinary Gifts, yet said he, God hath broken into my study and taken off my Chariot wheels. I have nothing worthy of God:" Oley's Life of Herbert. Cf. Dulnesse, III, 207.

DAte:

Not found in W. He looks back on his work.

Metre:

Unique.

SubJECT:

The King's messengers have affixed their mark and seized my beautiful estate. For the King I cultivated it, and I alone offered him such beauty. If he will now take it and me, I am content.

\section{Notes:}

1. Harbingers (as in The Church Militant, III, 365,1 . 84), messengers sent before to prepare lodging and announce the coming of the King. The mark here and in 1.35 is the chalking of the door with the royal letters. "Alexander Borgia said of the expedition of the French into Italy that they came with chalk in their hands to mark up their lodgings and not with weapons to force their passage:" Bacon, Novum Organum, Bk. I, XXXV.

"Before him a great prophet, to proclaim

His coming, is sent harbinger."

Milton, Par. Reg. 1. 70.

2. The hair turned gray. 


\section{THE FORERUNNERS}

The harbingers are come. See, see their mark!

White is their colour, and behold my head.

But must they have my brain? Must they dispark

Those sparkling notions, which therein were bred?

Must dulnesse turn me to a clod?

Yet have they left me, Thou art still my God.

Good men ye be to leave me my best room, Ev'n all my heart, and what is lodged there.

I passe not, I, what of the rest become, So Thou art still my God be out of fear. $\quad 10$

He will be pleased with that dittie; And if I please him, I write fine and wittie. 
3. Dispark; according to The Church Mulitant, III, 369, 1. 147, dispark cannot mean extinguish sparks, as might erroneously be inferred from the play on the word sparkling in 1.4 , but must mean drive from the inclosure.

6. Psalm xxxi, 14. A comforting phrase, like those in the note to A True Hymne, III, 27.

9. I passe not=I care not. So Drayton, Elegy of Poets and Poesy, 1. 185 (1627):

"Let such pieces be

Spoke of by those that shall come after me, I pass not for them."

Herbert has three other senses of pass, i. e. (1) to go beyond, as in The Search, III, 221, 1. 38; (2) to go over, as in The Search, III, 221, 1. 36; (3) to deliver over, as in Obedience, $\Pi, 385,1$. 8. The thought of these two lines is repeated in JAcuLA Prudentum : He loseth nothing that loseth not God.

11. Dittie=words, not music; as in The Banquet, III, 57, 1. 50, and Providence, III, 79, 1. 9.

13. For the value Herbert set on beautiful diction, see the longer account in Jordan, II, 91.

15, 16. For his early resolve, see Two Sonnets to HIS Mother, II, 79.

23. The broider'd coat again in Peace, II, 377, 1. 9.

26. Arras, the most beautiful of decorations, as canvas is the coarsest. So The Church-Porch, II, 47, 1. 270, and Dotage, III, 137, 1. 3. 
Farewell sweet phrases, lovely metaphors.

But will ye leave me thus? When ye before Of stews and brothels onely knew the doores, 15 Then did I wash you with my tears, and more, Brought you to Church well drest and clad. My God must have my best, ev'n all I had.

Lovely enchanting language, sugar-cane,

Hony of roses, whither wilt thou flie?

Hath some fond lover tic'd thee to thy bane?

And wilt thou leave the Church and love a stie?

Fie, thou wilt soil thy broider'd coat,

And hurt thy self and him that sings the note.

Let foolish lovers, if they will love dung,

With canvas, not with arras clothe their shame.

Let follie speak in her own native tongue.

True beautie dwells on high. Ours is a flame

But borrow'd thence to light us thither. 29

Beautie and beauteous words should go together.

Yet if you go, I passe not. Take your way!

For, Thou art still my God, is all that ye

Perhaps with more embellishment can say.

Go birds of spring! Let winter have his fee!

Let a bleak palenesse chalk the doore, 35

So all within be livelier then before. 
Date:

Not found in W. See also 1.10 and 11. Metre:

Used also in LeNT, II, 171.

SUBJECT:

The same as that of Vertue, III, 335. Perhaps like the previous poem, a lament that his beautiful work in poetry has been so incomplete. Notes:

1. Posie = nosegay, as in The Thanksgiving, II, 287, 1. 14, but with a double meaning.

7. Hand and heart=employment and love.

12. Sweetening the sourness of death by the suggestions of the next stanza.

15. Where the A pothecary useth either for loosing, Rubarb, or for binding, Bolearmena, the Parson useth damask or white Roses for the one, and plantaine, shepherd's purse, knot-grasse for the other, and that with better successe : The Country Parson, XXIII. So The Rose, II, 391, 1. 18, and Providence, III, 87, 1. 78. 


\section{LIFE}

I MADE a posie while the day ran by.

Here will I smell my remnant out, and tie

My life within this band.

But time did becken to the flowers, and they

By noon most cunningly did steal away

And wither'd in my hand.

My hand was next to them, and then my heart.

I took, without more thinking, in good part

Time's gentle admonition;

Who did so sweetly death's sad taste convey, 10 Making my minde to smell my fatall day,

Yet sugring the suspicion.

Farewell deare flowers! Sweetly your time ye spent, Fit, while ye liv'd, for smell or ornament,

And after death for cures.

I follow straight without complaints or grief, Since if my sent be good, I care not if

It be as short as yours. 
INTRODUCTORY

Compare with the first half of this poem the last part of The Country Parson, XXXIII.

DATE:

Not found in W.

Metre:

Used also in A Wreath, II, 319, The Answer, II, 351, and Love UnKNown, III, 179.

SuBJECT:

Distress so great should have had greater means of expression. Cf. Grieve Not, III, 257, 1. 31-36.

Notes :

1, 2. Jeremiah ix, 1; Lamentations ii, 18.

3. Herbert includes in grief bodily as well as mental suffering. Writing to Ferrar four months before his death, he speaks of himself as in the midst of my griefes.

5. Cf. Church-Rents and Schismes, III, 107, 1. 29. 10. The lesse world - man - is contrasted with the greater world. So MaN, II, 223, 1. 47.

15. Let my eyes do the running.

19. Accordingly this line is left without measure, tune, and time. For other cases see A True Hrmne, III, 27, 1. 20. 


\section{GRIEF}

O wно will give me tears? Come all ye springs,

Dwell in my head and eyes. Come clouds, and rain.

My grief hath need of all the watry things

That nature hath produc'd. Let ev'ry vein Suck up a river to supply mine eyes,

My weary weeping eyes, too drie for me

Unlesse they get new conduits, new supplies

To bear them out, and with my state agree. What are two shallow foords, two little spouts

Of a lesse world? The greater is but small, 10

A narrow cupboard for my griefs and doubts, Which want provision in the midst of all.

Verses, ye are too fine a thing, too wise

For my rough sorrows. Cease, be dumbe and mute,

Give up your feet and running to mine eyes, 15 And keep your measures for some lover's lute, Whose grief allows him musick and a ryme. For mine excludes both measure, tune, and time. Alas, my God! 
INTRODUCTORY :

The place of rest.

Date:

Not found in W. Probably written during the last Lenten Season (1. 61 and 73) of his life.

Metre:

Used also in Church-Musick, II, 199; Content, II, 353; Divinitie, III, 97; but without refrain.

SUBJECT:

A cry for union: Thou with me here, or I with thee there! The first five stanzas expand the first line of the refrain; the remainder, the second.

Notes:

2. Stay $=$ delay to come.

5. The only double refrain employed by Herbert.

14. Isaiah lxiii, 5 .

20. Cf. The Starre, II, 367, 1. 31.

22. Cf. Miserie, II, 251, 1. 8. Perhaps an allusion to Adam and Eve (as in the Prayer Before SerмON), and also to the apple as the sign of earthly love. 


\section{HOME}

Come Lord, my head doth burn, my heart is sick,

While thou dost ever, ever stay.

Thy long deferrings wound me to the quick.

My spirit gaspeth night and day.

O show thy self to me,

Or take me up to thee!

How canst thou stay, considering the pace

The bloud did make which thou didst waste?

When I behold it trickling down thy face,

I never saw thing make such haste. 10

O show thy, \&c.

When man was lost, thy pitie lookt about

To see what help in th' earth or skie.

But there was none, at least no help without;

The help did in thy bosome lie.

O show thy, \&c.

There lay thy sonne. And must he leave that nest,

That hive of sweetnesse, to remove

20

Thraldome from those who would not at a feast

Leave one poore apple for thy love?

O show thy, \&c. 
27. To me, so long ago baptized, wilt thou not appear? 31. Referring back to 1.2 and 7. If thou abidest absent from me, yet why should I from thee?

39. For Herbert's use of wink see Miserie, II, 257, 1. 62, and The Collar, III, 213, 1. 26. - Womankinde for him always represents temptation.

51. Men may forget themselves in pleasure; but when they come to their senses, it is to thee they turn. 
He did, he came. O my Redeemer deare,

After all this canst thou be strange?

So many yeares baptiz'd, and not appeare?

As if thy love could fail or change?

O show thy, \&c.

Yet if thou stayest still, why must I stay?

My God, what is this world to me,

This world of wo? Hence all ye clouds, away,

Away! I must get up and see.

O show thy, \&c.

What is this weary world, this meat and drink,

That chains us by the teeth so fast?

What is this woman-kinde, which I can wink

Into a blacknesse and distaste?

O show thy, \&c.

With one small sigh thou gav'st me th' other day

I blasted all the joyes about me,

And scouling on them as they pin'd away,

Now come again, said I, and flout me.

O show thy, \&c.

Nothing but drought and dearth, but bush and brake,

Which way so-e're I look, I see.

Some may dream merrily, but when they wake,

They dresse themselves and come to thee.

O show thy, \&c. 
55. "The harvest is the end of the world:" Matthew xiii, 39. In the next line leave, i. e. cease thinking about, is the emphatic word.

61. 2 Corinthians v, 8; Psalm lv, 6.

70. They beg that the rest of me also may accompany them.

76. The rhyme demands stay (1. 2), but I demand come. A somewhat similar break at the end of Denialu, II, 297, and A True Hymne, III, 27. Nine of the thirteen stanzas of this poem have a rhyme in $a$. 
We talk of harvests; there are no such things

But when we leave our corn and hay.

There is no fruitfull yeare but that which brings

The last and lov'd, though dreadfull day.

O show thy, \&c.

Oh loose this frame, this knot of man untie!

That my free soul may use her wing,

Which now is pinion'd with mortalitie,

As an intangled, hamper'd thing.

O show thy, \&c.

What have I left that I should stay and grone?

The most of me to heav'n is fled.

My thoughts and joyes are all packt up and gone,

And for their old acquaintance plead. $\quad 70$

O show thy, \&c.

Come dearest Lord, passe not this holy season,

My flesh and bones and joynts do pray.

And ev'n my verse, when by the ryme and reason

The word is, Stay, sayes ever, Come! 76

$O$ show thy self to me,

Or take me up to thee! 
Date:

Not found in W. A long period of life has passed, 1. 9.

Metre:

Unique.

SUBJECT:

The joy I felt when my Love first looked on me has been my stay in every ill.

Notes:

4. Probably the self-condemnation is excessive, but that it is not without ground is seen in such poems as Vanitie, II, 357, and Frailtie, II, 359.

5-8. The period here mentioned is described at greater length in the first three stanzas of Affuction, II, 339.

5. Sugred is used again in The Rose, II, 389, 1. 2, and Dulnesse, III, 209, 1. 21.

7. Embalme= bring balm or balsam to. Cf. Sunday, II, $175,1.5$.

18. $A$ mirth = that of 1.5 and 13.

20. Full-ey'd refers back to 1 . 1. The word is used again in VANitie, III, 133, i. 7.

21. The line is so splendid that Vaughan has borrowed it for his Misery:

"And with one glance, could he that gain To look him out of all his pain." 


\section{THE GLANCE}

When first thy sweet and gracious eye Vouchsaf'd ev'n in the midst of youth and night To look upon me, who before did lie

Weltring in sinne,

I felt a sugred strange delight,

Passing all cordials made by any art,

Bedew, embalme, and overrunne my heart,

And take it in.

Since that time many a bitter storm My soul hath felt, ev'n able to destroy,

Had the malicious and ill-meaning harm

His swing and sway.

But still thy sweet originall joy, Sprung from thine eye, did work within my soul, And surging griefs, when they grew bold, controll, And got the day.

If thy first glance so powerfull be, A mirth but open'd and seal'd up again, What wonders shall we feel when we shall see

Thy full-ey'd love!

When thou shalt look us out of pain, And one aspect of thine spend in delight More then a thousand sunnes disburse in light, In heav'n above. 
INTRODUCTORY :

Vaughan has imitated this poem in his Easter Day. Date:

Not found in W. Probably written on the last Easter of his life, 1. 2, 8, 10.

Metre:

Unique.

SuBJECT:

On Easter Day the habit of sadness must be abandoned.

Notes:

9. Unless thou opposest, thou mayst rise with Christ into newness of life.

11. Cf. Easter, II, 153, 1. 3.

12. An opposite word-play to that of The Temper, II, $313,1.7$. 


\section{$\checkmark$ THE DAWNING}

Awake sad heart, whom sorrow ever drowns!

Take up thine eyes, which feed on earth. Unfold thy forehead gather'd into frowns. Thy Saviour comes, and with him mirth, Awake, awake!

And with a thankfull heart his comforts take. But thou dost still lament, and pine, and crie, And feel his death, but not his victorie.

Arise sad heart! If thou dost not withstand,

Christ's resurrection thine may be,

Do not by hanging down break from the hand Which as it riseth, raiseth thee.

Arise, arise!

And with his buriall-linen drie thine eyes.

Christ left his grave-clothes that we might, when grief

Braws tears or bloud, not want an handkerchief. 


\section{INTRODUCTORY :}

This poem has been rewritten by Bishop Horne and by John Wesley. The latter, omitting the poetic audacities of Herbert, has made out of his poem a popular hymn. - "Piscator. And now, scholar, my direction for thy fishing is ended with this shower, for it has done raining. And now look about you and see how pleasently that meadow looks; nay, and the earth smells so sweetly too. Come, let me tell you what holy Herbert says of such days and showers as these, and then we will thank God that we enjoy them:" Walton's Angler, Ch. V.

\section{Date:}

Not found in W. Calm meditations on death. Metre:

Used also in Grace, II, 311.

SubJeCt:

The perpetuity of goodness; which is bright as the day, sweet as the rose, lovely as the spring, but excels them all in never fading.

\section{Notes:}

1. Sweet is repeated in each stanza. SUNDAY, II, 175, has a similar opening.

6. A color too bright will sometimes make the eyes blink. There may be an allusion to the same fact in Faith, II, 235, 1. 38, and in Frailtie, II, 359, 1. 16. 


\section{VERTUE}

SweET day, so cool, so calm, so bright,

The bridall of the earth and skie;

The dew shall weep thy fall to night,

For thou must die.

Sweet rose, whose hue angrie and brave 5

Bids the rash gazer wipe his eye;

Thy root is ever in its grave,

And thou must die. 
7. The Church-Porch, II, 47, 1. 266, and Joseph's CoAT, III, 301, 1. 3, are the only other passages where Herbert uses its.

11. $Y e=$ days and roses. - Close is the technical name for a cadence or conclusion of a musical phrase. So Milton, On the Morning of Christ's Nativity, 1. 90:

"The air such pleasure loth to lose, With thousand echoes still prolongs each heavenly close."

13. In the first three stanzas time is shown to be destructive; then suddenly the whole purpose of the poem appears in the last stanza, where time leaves virtue firm.

14. Gives = yields, bends, gives way. The New English Dictionary quotes a case of this usage from B. Googe, 1586: "The olive will give and bend, and so will the poplar, the willow."

15. Coal=live coals, i. e. the final conflagration. 2 Peter iii, 10. 
Sweet spring, full of sweet dayes and roses, A box where sweets compacted lie; 10 My musick shows ye have your closes, And all must die.

Onely a sweet and vertuous soul, Like season'd timber, never gives; But though the whole world turn to coal, 15 Then chiefly lives. 
INTRODUCTORY :

With this poem compare Death, II, 263.

Date:

Not found in W.

Metre:

Unique.

SubJECT:

Length of days, parting us from Grod, can never be the Christian's desire.

Notes:

4. It has become dulled by use.

10. Cf. Paradise, III, 39, 1. 11. 


\section{TIME}

Meeting with Time, slack thing, said I,

Thy sithe is dull, whet it for shame.

No marvell, Sir, he did replie,

If it at length deserve some blame.

But where one man would have me grinde it, Twentie for one too sharp do finde it.

Perhaps some such of old did passe, Who above all things lov'd this life;

To whom thy sithe a hatchet was,

Which now is but a pruning-knife.

Christ's coming hath made man thy debter, Since by thy cutting he grows better. 
13. The same thought in DeAth, II, 265, 1. 13-17.

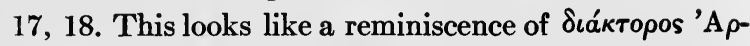
$\gamma \epsilon \iota o^{\prime} \tau \eta \mathbf{~}:$ Odyssey, XXIV, 1-14.

19. That = that which, the full subject being the following line.

20. Philippians i, 23.

22. We should write lengthens.

23. Wants =lacks, misses. The punishment of hell is twofold, - banishment from God, and positive suffering.

26. Herbert complains of the length of time, figuring it as portentously long since it lies outside eternity. See Revelation $x, 6$. But the mention of eternity shows Herbert to be seeking something never-ending. The last part of his desire contradicts the first (1. 2), and Time will parley no more. A similar discord is developed in Milton's lines On Time, written about the same date. 
And in his blessing thou art blest.

For where thou onely wert before An executioner at best,

Thou art a gard'ner now, and more An usher to convey our souls Beyond the utmost starres and poles.

And this is that makes life so long,

While it detains us from our God. 20

Ev'n pleasures here increase the wrong,

And length of dayes lengthen the rod.

Who wants the place where God doth dwell, Partakes already half of hell.

Of what strange length must that needs be Which ev'n eternitie excludes! 26

Thus farre Time heard me patiently, Then chafing said, This man deludes:

What do I hear before his doore?

He doth not crave lesse time, but more. 30 


\section{DAte:}

Not found in W.

Metre:

Unique.

SuBJECT :

The impotence of death.

Notes:

1, 2. 1 Corinthians $\mathrm{xv}, 55$.

3. Of history, fame, as in Self-Condemnation, III, 111, 1. 6. The same thought as in Content, II, 355, 1. 25.

6. Hebrews ii, 15. 


\section{A DIALOGUE-ANTHEME}

\section{Christian. Death}

Chr. Alas, poore Death, where is thy glorie?

Where is thy famous force, thy ancient sting?

Dea. Alas poore mortall, void of storie, 3

Go spell and reade how I have kill'd thy King. Chr. Poore death! And who was hurt thereby?

Thy curse being laid on him, makes thee accurst.

Dea. Let losers talk! Yet thou shalt die;

These arms shall crush thee. Chr. Spare not, do thy worst.

I shall be one day better then before;

Thou so much worse that thou shalt be no more. 


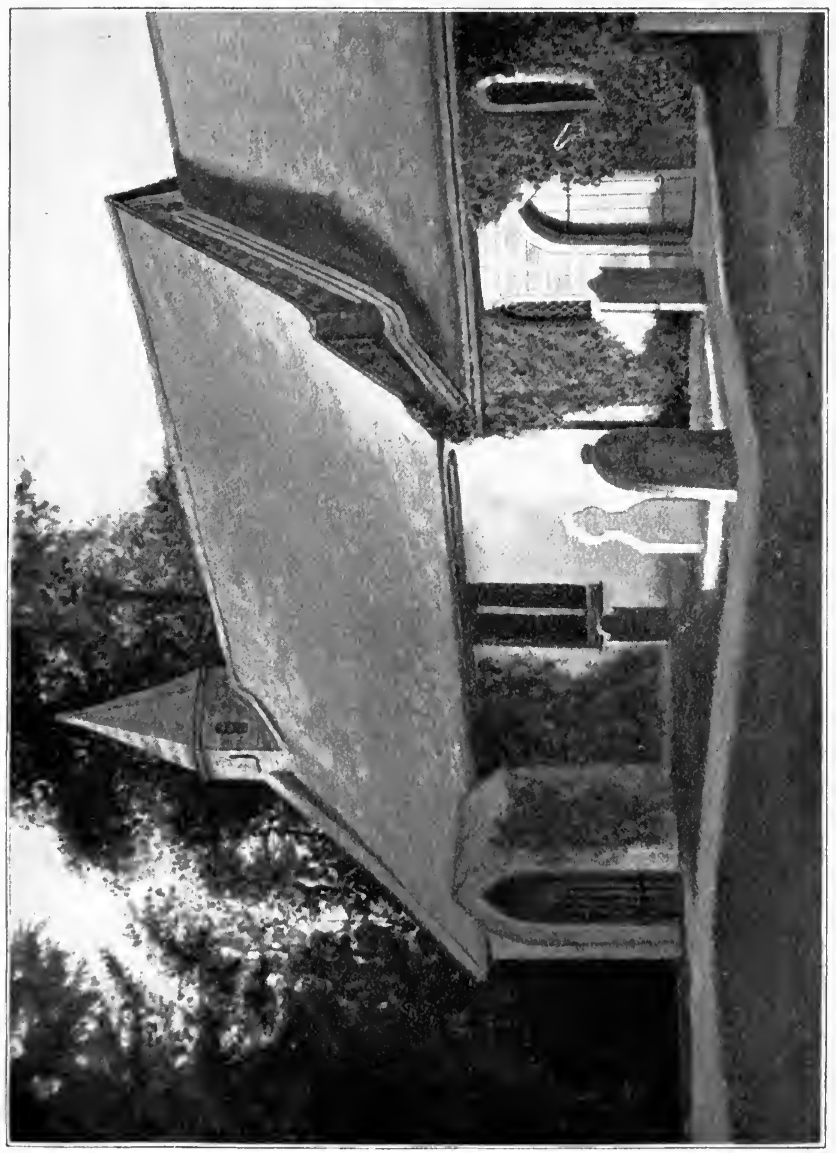





\section{XII}

ADDITIONAL AND DOUBTFUL POEMS 



\section{PREFACE}

RESIDES the poems composing The Temple, Herbert wrote other verse. That there was a considerable body of this, and that it was of a secular sort, has often been asserted. But the assertion rests on no evidence, and in my third Essay I have shown that it is inherently improbable. There are, however, a few additional poems which evidence of varying degrees of worth connects with Herbert's name, and these I gather into a final Group.

For some of them the evidence is very slight. As is shown in the notes, it is improbable that Herbert ever saw the lines to the Queen of Bohemia, or those to Lord Danvers and Sir John Danvers. Some of the Psalms here printed he may have written; but if so, they were justly rejected as unworthy to stand beside his beautiful rendering of The Twenty-Third Psalm. The Paradox has his name written upon it by an unknown copyist, and Nahum Tate thought The ConverT his. But none of these can be traced directly to his hand.

The case is different with The Holy Commu- nion, Love, Trinitie-Sunday, Even-Song, The • Knell, and Perseverance. These appear in the • Williams Manuscript, intermingled with its other 
poems. That manuscript, containing nearly half of the poems subsequently published in The Tem$\mathrm{PLF}_{\mathrm{w}}$ certainly originated in Herbert's study. Its general handwriting is that of a copyist; but its many corrections and its large body of Latin poems are in Herbert's hand. We must therefore accept these poems as his, or else suppose that, though composed by some one else, he had them copied as favorites into a book of his own verse. But their inferiority of style is quite as grave an objection to this supposition as to his own authorship. 'They must then be classed among his refuse work. In the years that intervened between the composition of the Williams Manuscript and his death his taste had ripened. Having already written other poems on The Holy Communion, Love, and TrinitieSunday, he rejected these, wrote later a substitute for the Even-Song, and struck out The Knell and Perseverance altogether. While these poems in themselves are youthful and of sinall aesthetic value, they are of importance as showing that Herbert did not preserve all his verse, but finally left for the printer only such as his critical taste approved.

Only one of the poems in this Group was so approved, The Church Militant. It is one of his four long and labored poems, and may have been designed as a kind of counterpart to THE Church-Porch. Ferrar printed it as an appendix or third part of The Temple. The name, The 
Temple, does not appear in the Williams Manuscript, which has no title-page. The running-title at the head of the pages is The Church. This is also the running-title of the central portion of the book as finally printed. Perhaps, then, Herbert's plan - or Ferrar's - was to call the total work The Temple, and to let it consist of three parts: the main structure, conceived as The ChuRch itself, with two adjuncts, - The Снurch-Porch, and The Church Militant. Yet the first two divisions are related so much more closely to each other than is either to the third that The CHURCH Militant may probably better be regarded as an altogether detached piece. Between The ChurchPorch and The Church the lines of SuperlimiNARE are inserted as a connecting link, while at the close of The Church stands the word FINIS and a Gloria. There seems, therefore, to be an intended detachment of The Church Militant from the whole framework of The Temple. The Envoy after The Church Militant must mark the close of this poem, and not of the entire book.

To preserve this detachment, I adopt the traditional arrangement and place The Church MiliTANT after the other authenticated poems. But it might well stand before them. To make plain the course of Herbert's development we should place it just after the Sonnens to His Mother. I, at least, have no doubt that it is his earliest considerable piece. Its style is more influenced by Donne than । 
is that of any of his other poems except the two Sonnets of 1610 . There is an indication, too, of youth in the fact that while no half-page of THE Church Militant shows sustained ease and mastery, one comes upon single lines of exceptional depth and promise, e. g.:

\section{Doing nought}

Which doth not meet with an eternall thought.

The sunne, though forward be his flight, Listens behinde him and allows some light Till all depart.

How low is he, If God and man be sever'd infinitely !

Setting affliction to encounter pleasure.

In vice the copie still exceeds

The pattern, but not so in vertuous deeds.

Bits of poetry like these, shining among lines which are too often declamatory, forced, and obscure, declare the age and promise of their author. Nor is objective evidence of an early date lacking. In line 242 the Thames is said to be in danger of pollution through mingling its stream with the Seine. Herbert was too good a courtier to have written so after 1624, when Prince Charles was betrothed to Henrietta Maria, the French Princess. The allusion, too, to America as the land of gold (l. 250) would be more natural at the time when the Virginia Trading Company was in full activity 
and hope than in the years after its dissolution in 1623.

But although The Church Militant is early, ${ }^{\circ}$ immature, and difficult in style, in its subject and . method of treatment it is of marked originality; for it is, so far as I can discover, the first sketch of general Church history in our language. Single periods of that history had been already treated, as by Bede in his account of the English Church. Lives of the Saints had been written, and studies of Christian Antiquity. Of controversial works, like Bishop Jewel's Apology, there was no lack. But hitherto no Englishman had attempted to survey the progress of the Church as it came forth from little Judaea and mightily overran all the lands of the West. This dramatic theme Herbert seized, treated it in bold outline, and made of his poem a veritable landmark in English ecclesiastical history. In this, as in religious poetry, he is the pioneer of a large company. But he could not bring his experiments in this field so near perfection as he did in that of the religious love-lyric. There he needed only to explore his own soul, while for even a good outline of Church history a solid body of scholarship was necessary; and this at that time was inaccessible. Herbert's account is accordingly, like all early history, inaccurate, partisan, and often credulous. It is an astonishing evidence of the independence of his mind that it was written at all, and in all probability written before he was thirty years 
of age. That this priority of Herbert in Church history has not been remarked shows how superficial has been the attention bestowed on his widely circulated little book.

Original, however, as Herbert is in the choice of a historical subject, he is no less original in his . treatment of it. Most historians of the Church conceive it as an ecclesiastical organization, whose construction and vicissitudes they explore, the development of whose power and ritual they trace, and whose scheme of doctrine they vindicate. The enemies of the Church are accordingly unbelievers, persecuting sovereigns, or nations which refuse to accept its sway.

With the progress of the Church in this sense Herbert is in no way concerned. What interests . him is the coming of righteousness on earth. The contests of the Church are not with those who question priestly authority. He never alludes to heretics, or creeds, or forms of worship; and when he mentions splendid outward organizations and the consolidation of ecclesiastical power, it is as a sign of danger, if not of decay. $\mathrm{He}$ is, in short, true to that conception of the Church continually announced in his poems, notably in SIoN, the conception which gave a name to his volume, and which I have abundantly discussed in my second and third Essays. He means by the Church the loving, temptable, aspiring, and ill-harmonized soul of man. It is no external institution. All its frame 
and fabrick is within. The Church history which he would write is a description of the way in which the new mode of affectionate holiness revealed by Jesus Christ has been intermittently adopted and rejected by the nations of Europe. His Church history is accordingly, like that of Jonathan Edwards afterwards, a genuine History of . Redemption.

It would be an error to claim for Herbert entire originality in this ethical idea of Church history. The greatest of the Fathers had thought of it in somewhat the same way. Augustine's City of God is a spiritual society of the righteous united by allegiance to a common divine Lord. It is true that, while Herbert is a man of piety, Augustine is also a statesman, with a range of vision, a complexity of interests, an acquaintance with men, and a philosophic grasp denied to Herbert. But all the more striking on this account becomes Herbert's independence. He knew and honored Augustine. He bequeathed a set of his works to his Fuggleston curate, Mr. Bostock. Undoubtedly his thoughts about The Church Militant were initiated by Augustine. But he did not allow himself to be dominated. He took from the City of God only what harmonized with his own individualistic genius, and under the name of The Church Militant pictured the world's growth in personal holiness.

The poem is divided into five parts, separated from one another by a refrain exalting the wisdom 
of God. Part I describes the migration of Religion from its early home in the East to its settlement in Egypt; Part II, the advance of Religion through Greece to establish its empire in the West; Part III, the parallel advance of Sin; Part IV, the conquest of Religion by Sin at Rome; Part V, the ineffective attempts through reformation to set Religion free from Sin, and the probability of farther struggle in future as the two move together through America westward.

In my fifth Essay is related the curious refusal of the Vice-Chancellor to license Herbert's book on account of lines 235 and 236 of The Church Militant:

Religion stands on tip-toe in our land, Readie to passe to the American strand.

This passage, as also line 247 , might suggest that Herbert was thinking of the Puritan migration, the only colonization ever undertaken from England with religious aims. Such thoughts are natural for us in looking back, but not for him when looking forward. Even if the dates allowed, we cannot suppose that he would have sympathized with companies of obscure and wilful sectaries. That was not his disposition. The Pilgrims, however, did not sail till 1620; the Puritans not till 1628. This latter date was just about the time when the Williams Manuscript was probably drawn up, and in it was included The Church Militant. At the time 
when the poem was written the Puritan migration was a small affair, and had attracted little attention. It is the Virginia Colony to which Herbert refers, that aristocratic colony with which his friend Ferrar was connected. What he has in mind is made clearer by a passage of The Country Parson, XXXII, in which he is planning work for younger sons: If the young Gallant think these Courses dull and phlegmatick, where can he busie himself better than in those new Plantations and discoveryes which are not only a noble but also, as they may be handled, a religious imployment? He simply means that on fresh soil religion has fresh opportunities. No other reference to America in The Temple speaks of it as religious ground; $\mathrm{cf}$. The Church-Porch, II, 25, 1. 100; The Pearl, II, 381, 1. 7; The Sonne, III, 161, 1. 10.

From this Group of Additional Poems I have withdrawn three as having special importance elsewhere. The lines reported by Walton as inscribed in the Bemerton Parsonage I have placed at the beginning of Group VIII. The Sonnets of 1610 mark the rise of that RESOLve which is set forth with early ardor, assurance, and comprehensiveness in the poems of Group II. 

ADDITIONAL AND DOUBTFUL POEMS 
INTRODUCTORY :

This and The SAcrifice are Herbert's only narrative poems. But efements of narrative enter into the first Affliction, The Bag, Humilitie, Love Unknown, The Pilgrimage, Peace, and The Pulley.

Date:

Found in W.

Metre:

Used also in Our Life is Hid, II, 283, and AN ANagram, III, 165.

SuBJECT:

A history of the Church from the earliest times to Herbert's own day, maintaining - as did Bishop Berkeley a hundred years later - that "Westward the tide of empire takes its way."

Notes:

1-4. Cf. Providence, III, 83, 1. 41-44.

11. Psalm lxxx, 8.

12. The more, i. e. because so early.

14. Trimme = refined, exquisite, cf. 1. 151 .

15. Genesis ix, 20, and The Bunch of Grapes, III, 217, 1. 24. 


\section{THE CHURCH MILITANT}

Almightie Lord, who from thy glorious throne Seest and rulest all things ev'n as one, The smallest ant or atome knows thy power, Known also to each minute of an houre.

Much more do Common-weals acknowledge thee And wrap their policies in thy decree, Complying with thy counsels, doing nought Which doth not meet with an eternall thought. But above all, thy Church and Spouse doth prove Not the decrees of power, but bands of love. 10 Early didst thou arise to plant this vine, Which might the more indeare it to be thine. Spices come from the East; so did thy Spouse, Trimme as the light, sweet as the laden boughs Of Noah's shadie vine, chaste as the dove,

Prepar'd and fitted to receive thy love.

The course was westward, that the sunne might light

As well our understanding as our sight. Where th' Ark did rest, there Abraham began To bring the other Ark from Canaan. 
19. The progress of the Church traced here I suppose to be as follows: Ur of Genesis xi, 31, is identified with Ararat of Genesis viii, 4; and the covenant with Noah, Genesis vi, 18, with that with Abraham, Genesis xvii, 19. I should think the reading would be to Canaan rather than from Canaan, as it is in W. and Genesis xii, 5. But the reference may be to Abraham's going into Egypt (Genesis xii, 10), out of which Moses subsequently led the Israelites, building that Ark of the Covenant (Exodus xxxvii, 1; Deuteronomy xxxi, 26) which Solomon finally placed in the Temple erected at Jerusalem.

24. When the old faith was shaken, the Jews hoped to confirm it by suppressing the new.

26. Ephesians ii, 14; Matthew xxvii, 51.

37. They $=$ its people.

38. The rise of monasticism in the Thebaid of Egypt.

41. These leaders of Egyptian monasticism in the fourth century Herbert reckons to be the real rulers of the country.

44. The river, which in ancient times produced a plague of frogs (Exodus viii, 3), now as a place of baptism produces Israelites indeed.

47. Psalm cxxxix, 17, Prayer-Book version. Perhaps also suggested by the refrain of Psalm cvii, 8 ? A similar partition of a poem by refrains occurs in Love Unknown, III, 179. 
Moses pursu'd this, but King Solomon

Finish'd and fixt the old religion.

When it grew loose, the Jews did hope in vain

By nailing Christ to fasten it again;

But to the Gentiles he bore crosse and all,

Rending with earthquakes the partition-wall.

Onely whereas the Ark in glorie shone,

Now with the crosse, as with a staffe, alone,

Religion, like a pilgrime, westward bent,

Knocking at all doores ever as she went.

Yet as the sunne, though forward be his flight,

Listens behinde him and allows some light

Till all depart; so went the Church her way,

Letting, while one foot stept, the other stay

Among the eastern nations for a time,

Till both removed to the western clime.

To Egypt first she came, where they did prove

Wonders of anger once, but now of love.

The ten Commandments there did flourish more

Then the ten bitter plagues had done before. 40

Holy Macarius and great Anthonie

Made Pharaoh Moses, changing th' historie.

Goshen was darknesse, Egypt full of lights,

Nilus for monsters brought forth Israelites.

Such power hath mightie Baptisme to produce

For things misshapen, things of highest use.

How deare to me, $O$ God, thy counsels are!

Who may with thee compare? 
51. $P o s^{\prime} d=$ brought to a stand, as in The ChurchPorch, II, 41, 1. 223.

54. There is a play here on learning one's letters and submitting to Christianity. They were sent back to learn the alphabet, then called Chriss-Crosse from the figure which stood at the beginning. Samuel Speed (1677) has the same play in his poem On Christ's Cross:

"Can we spell Chris-cross-row, and yet not read That Christ for us was dead?"

57. Took horse, i. e. religion took its departure from Greece.

59. Prefixed = foreordained.

64. Yeeld=grant, allow. So Milton: "I yield it just, said Adam, and submit:” Par. Lost, XI, 526.

65. To work the salvation of man, who was once allured to his ruin.

67. The great heart, i. e. of the Roman warrior, l. 63.

71. The pastoral staff became the Papal sceptre.

72. The Gregorian Calendar and the substitution of Christian holidays for pagan.

73. Alexander the Great hoped to establish a wide Grecian empire. 'These hopes were cut off by the quarrels of his successors, and were only finally realized when Constantine founded Constantinople. 
Religion thence fled into Greece, where arts

Gave her the highest place in all men's hearts. 50 Learning was pos'd, Philosophie was set,

Sophisters taken in a fisher's net.

Plato and Aristotle were at a losse

And wheel'd about again to spell Christ-Crosse.

Prayers chas'd syllogismes into their den,

And Ergo was transform'd into Amen.

Though Greece took horse as soon as Egypt did, And Rome as both, yet Egypt faster rid, And spent her period and prefixed time

Before the other. Greece being past her prime, Religion went to Rome, subduing those

Who, that they might subdue, made all their foes. The Warrier his deere skarres no more resounds, But seems to yeeld Christ hath the greater wounds, Wounds willingly endur'd to work his blisse 65 Who by an ambush lost his Paradise.

The great heart stoops and taketh from the dust

A sad repentance, not the spoils of lust,

Quitting his spear, lest it should pierce again

Him in his members who for him was slain.

The Shepherd's hook grew to a scepter here,

Giving new names and numbers to the yeare. But th' Empire dwelt in Greece, to comfort them Who were cut short in Alexander's stemme. 
77. $T h$ ' one and $t h$ ' other $=$ Arts and Prowesse.

84. Harbingers; see The Forenunners, III, 317, 1. 1.

85. Arts might in our time and country glorify the Church.

88. Religion waters the soil. In commenting on this passage an earlier editor, “R. S.," writes: "It is remarkable that Herbert should think of Germany, rather than Italy, in connection with religious art; but if he knew the engravings of Albert Dürer, it would cease to be surprising."

93. "The thought is here obscure and probably farfetched. When Constantius Chlorus Caesar in Britain died at York, his son Constantine was proclaimed and eventually became Emperor, and on his conversion gave, so to speak, a crown to the Church. Thus his rise in Britain, and his giving a crown to the Church, foreshadowed, says Herbert, or was a type, that hereafter Britain should give the Church a crown; meaning that at the Reformation Henry VIII would put down the usurped authority of the Church, and make it a national Church, and the State's head its supreme head:" A. B. Grosart. According to one tradition Helena, the mother of Constantine, was of British stock.

95. Sheet of paper. Is the Nicene Creed here intended? 
In both of these Prowesse and Arts did tame 75 And tune men's hearts against the Gospel came; Which using, and not fearing skill in th' one, Or strength in th' other, did erect her throne. Many a rent and struggling th' Empire knew, (As dying things are wont) untill it flew

At length to Germanie, still westward bending, And there the Churches festivall attending; That as before Empire and Arts made way, (For no lesse Harbingers would serve then they) So they might still, and point us out the place Where first the Church should raise her downcast face.

Strength levels grounds, Art makes a garden there, Then showres Religion and makes all to bear. Spain in the Empire shar'd with Germanie, But England in the higher victorie;

Giving the Church a crown to keep her state And not go lesse then she had done of late. Constantine's British line meant this of old, And did this mysterie wrap up and fold Within a sheet of paper, which was rent

From time's great Chronicle and hither sent.

Thus both the Church and Sunne together ran

Unto the farthest old meridian.

How deare to me, $O$ God, thy counsels are!

Who may with thee compare? 
103. In contrast with the western Babylon of 1. 182.

108. The onion was one of the most important foods of Egypt (Numbers xi, 5). Herbert had evidently heard that it was worshipped there. So had Donne, Anatomy of the World, 428: "For as the wine and corn and onions are Gods unto them." Probably both derived their information from Juvenal, Satire XV, 9-11. Compare also Pliny, Natural History, XIX, 6.

110. Their onions, devoted to God, being lost to diet.

120. We also worship that which is a mere means of life. Cf. Avarice, III, 113.

126. Make good=make permanent, hold.

127. For $=$ instead of. 
Much about one and the same time and place Both where and when the Church began her race, Sinne did set out of Eastern Babylon

And travell'd westward also. Journeying on

He chid the Church away where e're he came, 105

Breaking her peace and tainting her good name.

At first he got to Egypt and did sow

Gardens of gods, which ev'ry yeare did grow

Fresh and fine deities. They were at great cost

Who for a god clearely a sallet lost.

$\mathrm{Ah}$, what a thing is man devoid of grace,

Adoring garlick with an humble face,

Begging his food of that which he may eat,

Starving the while he worshippeth his meat!

Who makes a root his god, how low is he,

If God and man be sever'd infinitely!

What wretchednesse can give him any room

Whose house is foul, while he adores his broom?

None will beleeve this now, though money be

In us the same transplanted foolerie.

Thus Sinne in Egypt sneaked for a while;

His highest was an ox or crocodile

And such poore game. Thence he to Greece doth passe ;

And being craftier much then Goodnesse was,

He left behinde him garrisons of sinnes

To make good that which ev'ry day he winnes.

Here Sinne took heart, and for a garden-bed

Rich shrines and oracles he purchased. 
132. "The oracular response being in verse, Herbert says they hide their poison in the sweetness of verse:" A. B. Grosart. Cf. The Church-Porch, II, 15, 1. 5 .

134. Pull=draw; so Jordan, II, 89, 1. 12.

137. Him = Sinne.

138. Besides the mischief wrought by Sinne in false oracles, he created distrust in oracles of every kind, so that when near the Christian era the Sibyls prophesied the coming of the Messiah, they were only half believed. The so-called Sibylline Oracles were throughout the Middle Ages and for a long time after thought to be authentic Greek prophecies and consequently a testimony of heathenism to Christianity. In 1512 Michelangelo painted the Sibyls on the ceiling of the Sistine Chapel, side by side with the prophets.

147. Disparking=expelling from the park, as in THE Forerunners, III, 317, 1. 3. Cf. Milton's Hymn on the Morning of Christ's Nativity, xix.

149. Mohammed.

151. Trimme; cf. 1. 14.

152. $F o r=$ on account of.

154. Prodigies = too much to believe. 
He grew a gallant and would needs foretell As well what should befall as what befell.

Nay, he became a poet, and would serve

His pills of sublimate in that conserve.

The world came both with hands and purses full To this great lotterie, and all would pull.

But all was glorious cheating, brave deceit, 135

Where some poore truths were shuffled for a bait

To credit him, and to discredit those

Who after him should braver truths disclose.

From Greece he went to Rome; and as before

He was a God, now he's an Emperour.

Nero and others lodg'd him bravely there,

Put him in trust to rule the Romane sphere.

Glorie was his chief instrument of old,

Pleasure succeeded straight when that grew cold.

Which soon was blown to such a mightie flame 145

That though our Saviour did destroy the game,

Disparking oracles and all their treasure,

Setting affliction to encounter pleasure,

Yet did a rogue with hope of carnall joy

Cheat the most subtill nations. Who so coy, 150 So trimme, as Greece and Egypt? Yet their hearts Are given over, for their curious arts,

To such Mahometan stupidities

As the old heathen would deem prodigies.

How deare to me, $O$ God, thy counsels are! 155

Who may with thee compare? 
159. The negative virtue of keeping clear of infidelity is all that the Romish Church can show of its original divine foundation. Matthew xvi, 18.

169. Handsome $=$ seductive. Herbert distrusts the purity of Romish priests.

171. By the pretended oracles.

174. Christ as prophet, priest, and king. The three corresponding offices of Sinne are named in 1. 177179.

176. Inspiration was now confined to the Pope's utterances at Rome.

180. Dispensations and indulgences.

182. Revelation xvii, 5 . 
Onely the West and Rome do keep them free From this contagious infidelitie.

And this is all the Rock whereof they boast, As Rome will one day finde unto her cost. 160 Sinne being not able to extirpate quite The Churches here, bravely resolv'd one night To be a Church-man too and wear a Mitre; The old debauched ruffian would turn writer.

I saw him in his studie, where he sate 165

Busie in controversies sprung of late.

A gown and pen became him wondrous well. His grave aspect had more of heav'n then hell:

Onely there was a handsome picture by, To which he lent a corner of his eye.

As Sinne in Greece a Prophet was before, And in old Rome a mightie Emperour, So now being Priest he plainly did professe To make a jest of Christ's three offices;

The rather since his scatter'd jugglings were $175^{\star}$ United now in one, both time and sphere. From Egypt he took pettie deities, From Greece oracular infallibilities, And from old Rome the libertie of pleasure By free dispensings of the Churches treasure. 180 Then in memoriall of his ancient throne He did surname his palace, Babylon. 
184. As men of every speech were once obliged to migrate in all directions from Babel, Genesis xi, 9, so in reverse all nations flock to the new Babylon, 1 . 194.

190. His victories $=$ the victories of Sinne.

192. When they were carried captive to Babylon.

196. When in 1177 the Emperor Frederick Barbarossa submitted himself to Pope Alexander III, popular legend declares that the Pope set his foot on the Emperor's neck.

197. The Pope never leaves Rome.

200. Monks in appearance, but in reality statesmen. 204. He rode upon it as if it were the dullest of beasts. 
Yet that he might the better gain all nations, And make that name good by their transmigrations

From all these places, but at divers times, 185 He took fine vizards to conceal his crimes. From Egypt Anchorisme and retirednesse, Learning from Greece, from old Rome statelinesse; And blending these he carri'd all men's eyes, While Truth sat by counting his victories. 190 Whereby he grew apace and scorn'd to use Such force as once did captivate the Jews, But did bewitch and finely work each nation Into a voluntarie transmigration.

All poste to Rome. Princes submit their necks Either t' his publick foot or private tricks. 196 It did not fit his gravitie to stirre, Nor his long journey, nor his gout and furre. Therefore he sent out able ministers, Statesmen within, without doores cloisterers, 200 Who without spear, or sword, or other drumme Then what was in their tongue, did overcome; And having conquer'd, did so strangely rule, That the whole world did seem but the Pope's mule.

As new and old Rome did one Empire twist, 205 So both together are one Antichrist, Yet with two faces, as their Janus was, Being in this their old crackt looking-glasse. How deare to me, $O$ God, thy counsels are! Who may with thee compare? 
214. Made the latter throne to defray.

216. I. e. the constant accompaniments.

223. The better = the more complete.

224: The Church in our time falls as far short of the excellence of the early Church as modern sins exceed ancient.

228. The late Reformation should make us weep, as the second Temple did the Jews. Ezra iii, 12.

230. Isaiah $\mathrm{lx}, 2$.

233,234 . Widely as religion has extended itself since Judaean days, so great will be its contraction hereafter. 
Thus Sinne triumphs in Western Babylon,

Yet not as Sinne, but as Religion.

Of his two thrones he made the latter best, And to defray his journey from the east.

Old and new Babylon are to hell and night 215

As is the moon and sunne to heav'n and light.

When th' one did set, the other did take place,

Confronting equally the law and grace.

They are hell's land-marks, Satan's double crest,

They are Sinne's nipples, feeding th' east and west.

But as in vice the copie still exceeds

The pattern, but not so in vertuous deeds;

So though Sinne made his latter seat the better,

The latter Church is to the first a debter.

The second Temple could not reach the first,

And the late reformation never durst

Compare with ancient times and purer yeares, But in the Jews and us deserveth tears.

Nay, it shall ev'ry yeare decrease and fade, Till such a darknesse do the world invade

At Christ's last coming as his first did finde.

Yet must there such proportions be assign'd

To these diminishings as is between

The spacious world and Jurie to be seen. 
235, 236. "When Mr. Ferrar sent this Book to Cambridge to be Licensed for the Press, the Vice-Chancellor would by no means allow the two so much noted Verses,

Religion sts a Tip-toe in our Land, Ready to pass to the American Strand,

to be printed; and Mr. Ferrar would by no means allow the Book to be printed and want them. But after some time and some arguments for and against their being made publick, the Vice-Chancellor said: I knew Mr. Herbert well, and know that he had many heavenly Speculations, and was a Divine Poet; but I hope the World will not take him to be an inspired Prophet, and therefore I License the whole Book:" Walton's Life. In 1636 a piece by Ferrar himself, a translation of Carbo on the Instruction of Children, was refused License by the Cambridge authorities, as Oley mentions in his Life of Herbert.

246. Like fashions from Italy, sins travel; so that what was current in Italy this year may be expected to appear in France and England the next.

255. Giving them thy grace in return for what we have stolen from them. 
Religion stands on tip-toe in our land,

Readie to passe to the American strand.

When height of malice and prodigious lusts,

Impudent sinning, witchcrafts, and distrusts

(The marks of future bane) shall fill our cup

Unto the brimme and make our measure up;

When Sein shall swallow Tiber, and the Thames

By letting in them both pollutes her streams,

When Italie of us shall have her will,

243

And all her calender of sinnes fulfill ;

Whereby one may fortell what sinnes next yeare

Shall both in France and England domineer;

Then shall Religion to America flee.

They have their times of Gospel ev'n as we.

My God, thou dost prepare for them a way

By carrying first their gold from them away; 250

For gold and grace did never yet agree.

Religion alwaies sides with povertie.

We think we rob them, but we think amisse;

We are more poore, and they more rich by this.

Thou wilt revenge their quarrell, making grace

To pay our debts, and leave our ancient place

To go to them, while that which now their nation

But lends to us shall be our desolation. 
261. $T h e y=$ the Western nations.

263-266. Cf. 1. 75-88. All know the sort of Gospel which imperial Spain has championed. If that taught by the arts proves equally base, the Church will be crushed.

267. When they have gone round the world and find in the East once more the harbor from which they originally set forth.

270. The light of day and the light of truth both advance by going west. Cf. 1. 17, 97. This identification of Christ's progress and that of the sun is worked over in The Sonne, III, 161.

274. Encircles the globe. 
Yet as the Church shall thither westward flie, So Sinne shall trace and dog her instantly. $\quad 260$ They have their period also and set times Both for their vertuous actions and their crimes. And where of old the Empire and the Arts Usher'd the Gospel ever in men's hearts, Spain hath done one; when Arts perform the other, 265

The Church shall come, and Sinne the Church shall smother.

That when they haue accomplished the round, And met in th' east their first and ancient sound, Judgement may meet them both and search them round. 269

Thus do both lights, as well in Church as Sunne, Light one another and together runne.

Thus also Sinne and Darknesse follow still The Church and Sunne with all their power and skill.

But as the Sunne still goes both west and east, So also did the Church by going west 275 Still eastward go; because it drew more neare To time and place where judgement shall appeare. How deare to me, $O$ God, thy counsels are! Who may with thee compare? 
INTRODUCTORY :

This is the Envoy of The Church Minitant, not of the whole collection of poems.

Date:

Found in W., and early in style.

Metre:

Unique.

SubJect :

A Prayer that the evils of the Church may cease. Notes:

1. Repeated from Praise, II, 397, 1. 1.

9. His food=its power of nourishment. In the previous line $h i s=$ Sinne's.

14. It $=$ all the breath he possesses.

11-16. What is behind=what is still lacking. Cf. A True Hymne, III, 27, 1. 14, and Colossians i, 24. The meaning is: After being conquered by the cross, Sinne should reserve a store of breath for sighs. But Sinne's own breath will be insufficient. He will need to borrow from the wind in order to obtain enough for endless sighing. As regards the effect of sighs in exhausting breath, see AFFuicTION, III, 271, 1. 9. 


\section{L'ENVOY}

KING of glorie, King of peace, With the one make warre to cease;

With the other blesse thy sheep,

Thee to love, in thee to sleep.

Let not Sinne devoure thy fold,

Bragging that thy bloud is cold,

That thy death is also dead,

While his conquests dayly spread;

That thy flesh hath lost his food,

And thy Crosse is common wood.

Choke him, let him say no more,

But reserve his breath in store,

Till thy conquests and his fall

Make his sighs to use it all,

And then bargain with the winde

To discharge what is behinde.

Blessed be God alone,

Thrice blessed Three in One.

FINIS 
INTRODUCTORY :

Another poem with this title is given, II, 195. DATE:

This and the following five poems are found in W., but not in B. They are scattered throughout the manuscript, no two of them occurring together. In no one of them is there a single erasure or correction.

Metre:

Unique, but closely resembles The British Church, III, 101.

SUBJECT:

The question whether Christ enters into the communion bread is unimportant, if only he enter into the believer.

Notes:

9. Dr. Gibson quotes from Hooker, Eccles. Pol. V, LXVII, 12: "What these elements are in themselves it skilleth not, it is enough that to me which take them they are the body and blood of Christ."

13,18 . Whether thou enterest not into the bread but only into me, or into both bread and me, is only a question of a shorter or longer road. 


\section{THE HOLY COMMUNION}

O GRATIOUs Lord, how shall I know

Whether in these gifts thou bee so

As thou art everywhere?

Or rather so as thou alone

Tak'st all the Lodging, leaving none

For thy poore creature there.

First I am sure, whether Bread stay,

Or whether Bread doe fly away,

Concerneth Bread, not mee;

But that both thou and all thy traine

Bee there, to thy truth and my gaine,

Concerneth mee and Thee.

And if in comming to thy foes

Thou dost come first to them, that showes

The hast of thy good will.

Or if that thou two stations makest,

In Bread and mee, the way thou takest

Is more, but for mee still.

Then of this also I am sure,

That thou didst all those pains endure

To abolish Sinn, not Wheat.

Creatures are good and have their place.

Sinn onely, which did all deface,

Thou drivest from his seat. 
25. Impanation = God embodying himself in bread.

33. Eyesight.

38. "I. e. keeps that natural substance which is in the grass and herbs, from which all flesh is immediately or intermediately derived:" A. B. Grosart. 41. Meres $=$ limits. 
I could beleeve an Impanation

At the rate of an Incarnation,

If thou hadst dyde for Bread.

But that which made my soule to dye,

My flesh and fleshly villany,

That allso made thee dead.

That Flesh is there mine eyes deny.

And what should flesh but flesh discry,

The noblest sence of five?

If glorious bodies pass the sight,

Shall they be food and strength and might,

Even there where they deceive?

Into my soule this cannot pass.

Flesh (though exalted) keeps his grass,

And cannot turn to soule.

Bodyes and Minds are different spheres, 40

Nor can they change their bounds and meres,

But keep a constant pole.

This gift of all gifts is the best, Thy flesh the least that $I$ request.

Thou took'st that pledge from mee. 45

Give mee not that $I$ had before,

Or give mee that so $I$ have more.

My God, give mee all Thee. 
INTRODUCTORY :

Two other poems with this title are given, II, 83, 401.

Date:

Found in W., and early in style.

Metre:

Unique.

SubJect :

Similar to that of The Reprisall, II, 293; i. e. however we try to find God needy and ourselves givers, closer knowledge always proves the contrary. Notes:

8. Shrodely = shrewdly.

20. The matter =this matter, i. e. love. I shall then have conquered thee altogether.

24. I should have done what these three have failed to do. 


\section{LOVE}

Thou art too hard for me in Love.

There is no dealing wth thee in that Art.

That is thy Masterpeece, I see.

When I contrive and plott to prove Something that may be conquest on my part, 5 Thou still, O Lord, outstrippest mee.

Sometimes, whenas I wash, I say, And shrodely as I think, Lord wash my soule,

More spotted then my flesh can bee.

But then there comes into my way 10

Thy ancient baptism, which when I was foule

And knew it not, yet cleansed mee.

I took a time when thou didst sleep, Great waves of trouble combating my brest;

I thought it brave to praise thee then. 15 Yet then I found that thou didst creep Into my hart wth ioye, giving more rest Then flesh did lend thee back agen.

Let mee but once the conquest have Vpon the matter, 'twill thy conquest prove. 20 If Thou subdue mortalitie,

Thou dost no more then doth the grave. Whereas if I orecome thee and thy Love, Hell, Death, and Divel come short of mee. 


\section{INTRODUCTORY :}

Another poem with this title is given, II, 161 . Date:

Found in W., and early in style.

Metre:

Unique.

SubJECT:

Reality is everywhere threefold.

Notes:

2. Two, i. e. body and soul. Cf. MaN's Medley, III, 125.

11-18. The first Theefe, Satan, though he had a kind of belief in God (James ii, 19), did not acknowledge the threefold order of God, saints, and angels, or heaven, earth, and hell. He is consequently shut out from God or heaven, and confined to the last two. But whoever rightly confesses God has all. 


\section{TRINITIE-SUNDAY}

$\mathrm{He}$ that is one

Is none.

Two reacheth thee

In some degree.

Nature and Grace

With Glory may attaine thy Face.

Steele and a flint strike fire.

Witt and desire

Never to thee aspire

Except life catch and hold those fast.

That which beleefe

Did not confess in the first Theefe

His fall can tell

From Heaven through Earth to Hell.

Lett two of those alone

To them that fall,

Who God and Saints and Angels loose at last.

Hee that has one

Has all. 
DAte:

In W. this appears in place of the Even-Song (III, 59) of B. This fact alone might well prove W. to be an early draft of Herbert's verse.

Metre:

Unique, but differs only in rhyming system from The Temper, II, 315.

SubJeCT:

God the light of all his creatures. Notes :

15. Darker $=$ more difficult to see.

17. This, i. e. that thou art not to be seen. 


\section{EVEN-SONG}

The Day is spent, and hath his will on mee.

$I$ and the Sunn have runn our races.

I went the slower, yet more paces;

For I decay, not hee.

Lord, make my Losses up, and sett mee free;

That I, who cannot now by day 6

Look on his daring brightnes, may

Shine then more bright then hee.

If thou deferr this light, then shadow mee;

Least that the Night, earth's gloomy shade,

Fouling her nest, my earth invade,

As if shades knew not thee.

But thou art light and darknes both togeather.

If that bee dark we cannot see,

The sunn is darker than a tree, 15

And thou more dark then either.

Yet thou art not so dark since I know this But that my darknes may touch thine, And hope, that may teach it to shine, Since Light thy Darknes is.

O lett my soule, whose keyes I must deliver

Into the hands of senceles Dreams

Which know not thee, suck in thy beams

And wake with thee for ever. 
INTRODUCTORY :

The $K_{N E L L}$ would seem to be used in the sense of

a call to church rather than to a funeral.

Date:

Found in W.

Metre:

Unique.

SUBJECT:

Prayer for deliverance from worldly allurement. The poem may refer to Herbert's frequent subject, vacillation between the church and the world. Notes:

2. The perplexed soule cannot be the dead.

3. Wishly=wistfully.

14. The reverse of Affliction, III, 269, 1. 10. 


\section{THE KNELL}

The Bell doth tolle.

Lord, help thy servant whose perplexed soule

Doth wishly look

On either hand,

And sometimes offers, sometimes makes a stand,

Struggling on th' hook.

Now is the season,

Now the great combat of our flesh and reason.

O help, my God!

See, they breake in,

Disbanded humours, sorrows, troops of Sinn,

Each with his rodd.

\section{Lord make thy blood}

Convert and colour all the other flood

And streams of grief,

That they may bee

Julips and Cordials when wee call on thee

For some relief. 
Date:

Found in W.

Metre:

Unique.

SUBJECT:

What warrant have I that my highest moods shall be permanent? Only thy steadfastness. Cf. ThE Temper, II, 315.

Notes:

3. Move=intend to speak, as in The Method, III, 197, 1. 6.

6. $M y$ iudgement=the condemnation of me. 1 Corinthians ix, 27.

8. Remains concealed with thee.

16. Psalm xxviii, 1. 


\section{PERSEVERANCE}

My God the poore expressions of my Love,

Which warme these lines and serve them up to thee

Are so as for the present I did move,

Or rather as thou movedst mee.

But what shall issue, - whether these my words 5

Shall help another but my iudgment bee, As a burst fouling-peece doth save the birds

But kill the man, - is seal'd with thee.

For who can tell though thou hast dyde to winn

And wedd my soule in glorious paradise, 10

Whether my many crymes and use of sinn

May yet forbid the banns and bliss?

Onely my soule hangs on thy promisses,

Wth face and hands clinging unto thy brest;

Clinging and crying, crying without cease,

Thou art my rock, thou art my rest. 
Tithe:

"This piece is from Miscellanea Sacra, or Poems on Divine and Moral Subjects, collected by $\mathrm{N}$. Tate, second edition, 1698, p. 51, where it is headed The Convert, An Ode written by Mr. George Herbert. It is to be regretted that Tate does not inform us whence he derived this Ode. But as he was well circumstanced to procure Mss. and as others of eminent names first published by him have been authenticated, there is every probability that he had an autograph of this poem:" A. B. Grosart. Metre:

Unique.

SUBJECT:

My eyes, voice, and heart, which have hitherto been given over to women, shall henceforth be dedicated to God.

Notes:

7. In Vanitie, II, 357, 1. 3, an experience is hinted similar to that lamented here. Cf. also Frailutie, II, 359, 1. 3, and Номе, III, 327, 1. 39.

18. The Temple. This word is suspicious. An imitator, remembering the title of Herbert's book, would be likely to use it; but it is rarely used by Herbert himself. See note on Sron, III, 264. 


\section{THE CONVERT}

IF ever tears did flow from eyes, If ever voice was hoarse with cries, If ever heart was sore with sighs, Let now my eyes, my voice, my heart, Strive each to play their part.

My eyes, from whence these tears did spring, Where treach'rous Syrens us'd to sing, Shall flow no more, untill they bring A deluge on my sensual flame, And wash away my shame.

My voice, that oft with foolish lays, With vows and rants and senseless praise, Frail Beauty's charms to heav'n did raise, Henceforth shall only pierce the skies In penitential cryes.

My heart, that gave fond thoughts their food, Till now averse to all that's good, The Temple where an idol stood, Henceforth in sacred flames shall burn, And be that idol's urn. 


\section{INTRODUCTORY :}

"A little before his death Doctor Donne caused many Seals to be made, and in them to be ingraven the figure of Christ crucified on an Anchor (the emblem of hope) and of which Doctor Donne would often say, Crux mihi Anchora. These Seals he gave or sent to most of those friends on which he put a value; and at Mr. Herbert's death these Verses were found wrapt up with that Seal which was by the Doctor given to him:" Walton's Life.

Date:

Donne died in 1631. L. 2 refers to him as already dead.

Metre:

Used also in AN Anagram, III, 165, and The Church Militant,III, 359.

SuBJECT:

The Cross our stay.

Notes:

2. Rev. J. J. Daniell in his Life of Herbert, 222, says that this seal is now in the possession of Rev. W. Ayerst, of Cambridge.

4. Hebrews vi, 19. 


\section{ON AN ANCHOR-SEAL}

When my dear Friend could write no more, He gave this Seal, and so gave ore.

When winds and waves rise highest, I am sure This Anchor keeps my faith; that, me secure. 
INTRODUCTORY :

Herbert thanked Donne for his seal in some Latin verses, which he also translated into English.

Date:

These lines may have been written before the death of Donne in 1631. Yet not long before. According to the preceding poem, and according to Walton, too, Donne died soon after he sent the seal.

Notes :

14-17. Death sought to break up my friend's communications with me. This seal renders them forever secure. 


\section{TO JOHN DONNE, D. D.}

ON HIS SEAL OF CHRIST AND AN ANCHOR

Although the Cross could not Christ here detain, Though nail'd unto't, but He ascends again, Nor yet thy eloquence here keep Him still, But only while thou speakst, this Anchor will. Nor canst thou be content unless thou to

This certain Anchor add a Seal; and so The water and the earth both unto thee Do owe the symbole of their certainty.

When Love, being weary, made an end Of kind expressions to his friend,

He writ; when's hand could write no more,

He gave the Seal and so left o're.

How sweet a friend was he who, being griev'd

His letters were broke rudely up, believ'd 14

'T was more secure in great Love's commonweal,

Where nothing should be broke, to add a Seal!

Let the world reel. We and all ours stand sure.

This holy cable's of all storms secure. 
INTRODUCTORY :

From Rawlinson Manuscripts in the Bodleian Library, Oxford, signed G. Herbert. First printed by Pickering. Reprinted with corrections by Dr. Grosart, who calls attention to the poem of the same name and subject in the Synagogue of Christopher Harvey as evidence that Harvey supposed this poem to be by Herbert. With it compare Herbert's letter to his mother, I, 402.

Metre:

Unique.

SUBJECT:

That the sick are in better case than the whole. Notes:

6. The emphatic word is yourselves.

12. "Here used for one who is in the mean or middle state between the two; neither in perfect health nor under the full sway of sickness; one who was, in fact, in the state in which Herbert then was - failing:" A. B. Grosart.

14. "A curious ellipse of with. Can which be an error for where?" A. B. Grosart.

17. People sometimes weep for joy. 


\section{A PARADOX}

THAT THE SICK ARE IN BETTER CASE THAN THE WHOLE

You who admire yourselves because

You neither grone nor weepe,

And think it contrary to nature's laws

To want one ounce of sleepe,

Your strong beleife

Acquits yourselves and gives the sick all greife.

Your state to ours is contrary, That makes you thinke us poore;

So Black-Moores thinke us foule, and wee Are quit with them, and more.

Nothing can see

And judg of things but mediocrity.

The sick are in themselves a state

Which health hath naught to doe.

How know you that our tears p'ceed from woe,

And not from better fate? 16

Since that Mirth hath

Her waters alsoe and desyred bath. 
20. On the expenditure of sighing, see note on AFFLICTION, III, 271, 1. 10.

31. With this stanza compare the fourth of The Size, III, 193. 
How know you that the sighs wee send

From want of breath p'ceede,

Not from excesse? And therefore we do spend

That which we do not neede;

So trembling may

As well show inward warblings as decay.

Cease then to judge calamityes

By outward forme and shew;

But view yourselves and inward turn your eyes,

Then you shall fully know

That your estate

Is, of the two, the farre more desperate.

You allwayes feare to feele those smarts

Which we but sometimes prove;

Each little comfort much affects our hearts,

None but gross joyes you move.

Why then confesse

Your feares in number more, your joyes are lesse?

Then for yourselves not us embrace

Plaints to bad fortune due,

For though you visitt us and plaint our case,

Wee doubt much whether you

Come to our bed

To comfort us, or to be comforted. 


\section{INTRODUCTORY}

The following Psalms were collected and edited by

Dr. Grosart and accompanied by this note:

"These Psalms are taken from the following now extremely rare book:

\section{PSALMS AND HYMNS}

\section{IN SOLEMN MUSICK \\ Of Foure Parts,}

Or the common tunes to the Palus in Metre:

Used in Parish-Churches.

Also six Hymns for one Voice to the Organ.

For God is King of all the earth; sing ye praises with understanding.

Psalm xlvii, 7.

By John Playford.

[Picture of K. David playing, surrounded by a square margin containing the music of Gloria in excelsis, Deo Cantate, \&c.]

London: Printed by W. Godbid for J. Playford at his shop in the Inner-Temple, 1671. 


\section{PSALM II}

WHY are the heathen swell'd with rage, The people vain exploits devise? The kings and potentates of earth Combin'd in one great faction rise?

And taking councels 'gainst the Lord And 'gainst His Christ, presume to say, 'Let us in sunder break their bonds, And from us cast their cords away.'

But He that sits in heaven shall laugh, The Lord Himself shall them deride; Then shall He speak to them in wrath, And in sore anger vex their pride.

'But I am God, and seated King On Sion, His most holy hill;

I will declare the Lord's decree, Nor can I hide His sacred will.' 
The book is dedicated to William Sancroft, D. D., Dean of St. Paul's. In the Preface occur these explanations: 'To those which are Bishop King's there is H. K.; those of Mr. [Miles] Smith [yet living], M. S.; those with G. H. are supposed to be Mr. George Herbert's." ",

A Gloria and these five have the initials G. H. attached. Dr. Grosart prints two more which he thinks, on slender evidence, are by Herbert. 
He said to Me, 'Thou art My Son, This day have I begotten Thee; Make Thy request, and I will grant, The heathen shall Thy portion be.

Thou shalt possess earth's farthest bounds, And there an awful sceptre sway; Whose pow'r shall dash and break them all, Like vessels made of brittle clay.'

Now therefore, $\mathrm{O}$ ye kings, be wise; Be learnèd, ye that judge the earth; Serve our great God in fear; rejoice, And tremble in your highest mirth.

$\mathrm{O}$ kiss the Son, lest He be wroth, And straight ye perish from the way: When once His anger burns, thrice blest Are all that make the Son their stay. 


\section{PSALM III}

How are my foes increasèd, Lord!

many are they that rise

Against me, saying, for my soul no help in God there is.

But Thou, O Lord, ar't still the shield of my deliverance;

Thou art my glory, Lord, and $\mathrm{He}$ that doth my head advance.

I cry'd unto the Lord, He heard me from His holy hill;

I laid me down and slept, I wak't; for God sustain'd me still. Aided by Him, I will not fear ten thousand enemies, Nor all the people round about that can against me rise.

Arise, O Lord, and rescue me; save me, my God, from thrall;

' $T$ is Thou upon the cheek-bone smit'st mine adversaries all.

And Thou hast broke th' ungodly's teeth: salvation unto Thee Belongs, O Lord; Thy blessing shall upon Thy people be. 


\section{PSALM IV}

Lord, hear me when I call on Thee,

Lord of my righteousness;

$O$ Thou that hast enlargèd me when I was in distress.

Have mercy on me, Lord, and hear the prayer that I frame;

How long will ye, vain men, convert my glory into shame?

How long will ye seek after lies, and vanity approve?

But know the Lord Himself doth chuse the righteous man to love.

The Lord will hearken unto me when I his grace implore;

$\mathrm{O}$ learn to stand in awe of Him, and sin not any more. 
Within your chamber try your hearts; offer to God on high

The sacrifice of righteousness, and on His grace rely.

Many there are that say, ' $O$ who will show us good?' But, Lord,

Thy countenance's cheering light do Thou to us afford.

For that, O Lord, with perfect joy shall more replenish me

Than worldlings joy'd with all their store of corn and wine can be.

Therefore will I lie down in peace and take my restful sleep;

For Thy protection, Lord, alone shall me in safety keep. 


\section{PSALM VI}

REBUKE me not in wrath, O Lord, nor in Thine angè chasten me;

$\mathrm{O}$ pity me; for I, O Lord, am nothing but infirmitie.

O heal me, for my bones are vex'd, my soul is troubled very sore;

But, Lord, how long so much perplex'd shall $I$ in vain Thy grace implore?

Return, O God, and rescue me, my soul for Thy great mercy save;

For who in death remember Thee? or who shall praise Thee in the grave?

With groaning I am wearied, all night I make my couch to swim, And water with salt tears my bed; my sight with sorrow waxeth dim. 
My beauty wears and doth decay, because of all mine enemies; But now from me depart away, all ye that work iniquities.

For God Himself hath heard my cry; the Lord vouchsafes to weigh my tears; Yea, He my prayer from on high and humble supplication hears.

And now my foes the Lord will blame that e'rst so sorely vexèd me, And put them all to utter shame, and to confusion suddainly.

Glory, honour, power, and praise to the most glorious Trinity; As at the first beginning was, is now, and to eternity. 


\section{PSALM VII}

Save me, my Lord, my God, because

I put my trust in Thee;

From all that persecute my life,

O Lord, deliver me.

Lest like a lion swollen with rage he do devour my soul;

And piece-meal rent it, while there's none his malice to controul.

If I have done this thing, O Lord, if I so guilty be;

If I have ill rewarded him that was at peace with me;

Yea, have not oft deliver'd him that was my causeless foe, Then let mine enemie prevail unto mine overthrow. 
Let him pursue and take my soul; yea, let him to the clay

Tread down my life, and in the dust my slaughter'd honour lay.

Arise in wrath, $\mathrm{O}$ Lord, advance against my foes' disdain;

Wake and confirm that judgment now which Thou did'st foreordain.

So shall the people round about resort to give Thee praise;

For their sakes, Lord, return on high, and high Thy glory raise.

The Lord shall judge the people all;

O God, consider me

According to my righteousness

and mine integritie. 
The wicked's malice, Lord, confound, but just me ever guide;

Thou art that righteous God by whom the hearts and rains are try'd.

God is my shield, Who doth preserve those that in heart are right;

He judgeth both the good and those that do His justice slight.

Unless the wicked turn again, the Lord will whet His sword;

His bow is bent, His quiver is with shafts of vengeance stor'd.

The fatal instruments of death in that preparèd lie;

His arrows are ordain'd 'gainst him that persecuteth me. 
Behold the wicked travelleth with his iniquitie;

Exploits of mischief he conceives, but shall bring forth a lye.

The wicked diggèd, and a pit for others' ruine wrought; But in the pit which he hath made shall he himself be caught.

To his own head his wickedness shall be returned home; And on his own accursèd pate his cruelty shall come.

But I, for all His righteousness, the Lord will magnifie;

And ever praise the glorious Name of Him that is on high. 


\section{GLORIA TO PSALM XXIII}

To Father, Son, and Holy Ghost, one consubstantial Three, All highest praise, all humblest thanks, now and for ever be. 
INTRODUCTORY:

"By the same [George Herbert] Orator of [the] University at Cambridge: pinned on the curtaine of the picture of the old Sir John Danvers, who was both a handsome and a good man. Sir John Danvers, senior, married Elizabeth Nevill, fourth daughter and co-heiress of John, Lord Latimer. She re-married Sir Edmund Carey. George Herbert of Bemerton, having been in the first year of his age in 1594, when Sir John Danvers, senior, died, could only have known his character by report:" Aubrey and Jackson's Wiltshire, p. 224. There is nothing in the style of these lines to connect them with Herbert. 


\section{ON SIR JOHN DANVERS}

Passe not by;

Search, and you may

Find a treasure

Worth your stay.

What makes a Danvers

Would you find?

In a fayre body

A fayre mind.

Sir John Danvers' earthly part

Here is copied out by art;

But his heavenly and divine

In his progenie doth shine.

Had he only brought them forth,

Know that much had been his worth.

Ther's no monument to a sonne:

Read him there, and I have done. 
INTRODUCTORY :

From the monument in the church of Dauntsey. Date:

Dr. Grosart writes: "There was but one Lord Danvers, viz.: Henry Danvers, second son of Sir John Danvers, Kt. by Lady Elizabeth, daughter of John Nevil, Lord Latimer. He was born at Dauntsey, Wilts, 28th. of June, 1573; created Baron Danvers in 1603, and Earl of Danby, 7th. of February, 1625-6. He died 20th. of January 1643-4, and was buried at Dauntsey. The death of Lord Danvers in 1643-4 makes it clear that the lines inscribed on his monument, and to which contemporaneously was added the name of G. Herbert, must have been composed by him for some other and applied to Lord Danvers, he having predeceased the Earl in 1632-3." A simpler explanation of these opposing dates is that the lines were erroneously attributed to Herbert, of whose style they show little trace.

Notes:

5. Weares $=$ wears away.

7. "The tears which are shed for him by mourners dissolve thy frame:" A. B. Grosart. 


\section{ON LORD DANVERS}

SACRED marble, safely keepe

His dust, who under thee must sleepe

Untill the graves againe restore

Theire dead, and time shal be no more. 4

Meanewhile, if hee (which all thinges weares)

Doe ruine thee, or if the tears

Are shed for him dissolve thy frame, Thou art requited; for his fame, His vertues, and his worth shal bee Another monument for thee. 


\section{TO THE QUEENE OF BOHEMIA}

INTRODUCTORY:

The Princess Elizabeth, eldest daughter of James I, was born in Scotland, August 19, 1596. On February 14, 1612-13, she married Frederic V, Duke of Bavaria and Elector Palatine of the Rhine, who in 1619 was elected King of Bohemia. Defeated and driven from his domains by the Emperor Ferdinand, he died at Mainz, in 1632. Elizabeth died in London in 1661-2, and was buried in Westminster Abbey. She was the mother of Prince Rupert. Poems in honor of her were written by many poets of the day, among them Dr. Donne. That by Sir H. Wotton is probably the best known. Quarles was at one time in her service. In 1619 Sir Francis Nethersole resigned the Oratorship at Cambridge in order to become her Secretary, and Herbert was appointed Orator in his place. 


\section{TO THE QUEENE OF BOHEMIA}

BRIGHT soule, of whome if any countrey knowne Worthy had bin, thou hadst not lost thine owne; No Earth can bee thy Jointure, For the sunne And starres alone unto the pitch doe runne And pace of thy swift vertues; onely they 5 Are thy dominion. Those that rule in clay Stick fast therein, but thy transcendent soule Doth for two clods of earth ten spheres controule. And though starres shott from heaven loose their light,

Yet thy brave beames, excluded from their right, Maintaine their Lustre still, and shining cleare Turn watrish Holland to a chrystalline sphere. Mee thinkes, in that Dutch optick I doe see Thy curious vertues much more visibly.

There is thy best Throne, for afflictions are 15 A foile to sett of[f] worth and make it rare. Through that black tiffany thy vertues shine Fairer and richer. Now wee know what's thine, And what is fortune's. Thou hast singled out Sorrowes and griefs, to fight with them about 20 At their owne weapons, without pomp or state To second thee against their cunning hate. 
DAte:

Dr. Grosart has printed this, for the first time, from the Harleian Manuscript 3910, pp. 121-2, where it appears with the letters G. H. at its head. That it was written by Herbert there is no other evidence. It is not unlike Herbert's early style; but the allusions in the poem itself are suspicious. The Queen is represented as living in Holland after the overthrow of her cause. In Holland she did live at intervals during the last ten years of her husband's life ; but her residence there was more continuous after his death. The compliment, too, of 1. 34, that an undivided Majestye is still to be seen in her face, suggests that her husband is dead. If so, Herbert could not have written the poem, as he and Frederic died in the same year.

Metre:

The same as that of The Church Multant, III, 359. 
$O$ what a poore thing ' $t$ is to be a Queene, When scepters, state, Attendants are the screene Betwixt us and the people! When-as glory 25 Lyes round about us to helpe out the story; When all things pull and hale, that they may bring A slow behaviour to the style of king; When sense is made by Comments, but that face Whose native beauty needs not dresse or lace 30 To serve it forth, and being stript of all Is self-sufficient to bee the thrall Of thousand harts, that face doth figure thee And show thy undivided Majestye;

Which misery cannot untwist, but rather

Addes to the union, as lights doe gather

Splendour from darknes. So close sits the crowne About thy temples that the furious frowne Of opposition cannot place thee where

Thou shalt not be a Queene, and conquer there. Yet hast thou more dominions: God doth give Children for kingdomes to thee; they shall live To conquer new ones, and shall share the frame Of th' universe, like as the windes, and name The world anew. The sunne shall never rise 45 But it shall spy some of their victories.

Their hands shall clipp the Eagle's winges and chase 


\section{Notes:}

17. Tiffany=gauze.

20. About, probably a bout.

47. The Imperial Eagles.

53. Do not fear to let your sons engage in war.

56. Thence $=$ Bohemia.

62. Holland.

66. Meet theire tast $=$ fit for their taste. 
Those ravening Harpyes, which peck at thy face, At once to Hell without a baiting while At Purgatory, their inchanted Ile,

And Paris garden. Then let their perfume And Spanish sents, wisely layd up, presume To deale with brimstone, that untamed stench Whose fier, like their malice, nought can quench. But joyes are stor'd for thee; thou shalt returne Laden with comforts thence, where now to morne Is thy chief government, to manage woe, To curbe some Rebell teares which faine would flow,

Making a Head and spring against thy Reason.

This is thy empire yet, till better season 60

Call thee from out of that surrounded Land;

That habitable sea and brinish strand, Thy teares not needing. For that hand Divine, Which mingles water with thy Rhenish wine, Will power full joyes to thee; but dregs to those And meet theire tast who are thy bitter foes. 66 


\section{L'ENVOY}

Notes:

2. Psalm i, 3.

10. Maine $=$ the ocean. 


\section{L'ENVOY}

Shine on, Majestick soule, abide Like David's tree, planted beside The Flemmish rivers; in the end Thy fruite shall with their drops contend; Great God will surely dry those teares, 5 Which now that moist land to thee beares. Then shall thy Glory, fresh as flowers In water kept, maugre the powers Of Divell, Jesuitt, and Spaine, From Holland sail into the Maine:

Thence wheeling on, it compass shall This oure great Sublunary Ball, And with that Ring thy fame shall wedd Eternity into one Bedd. 



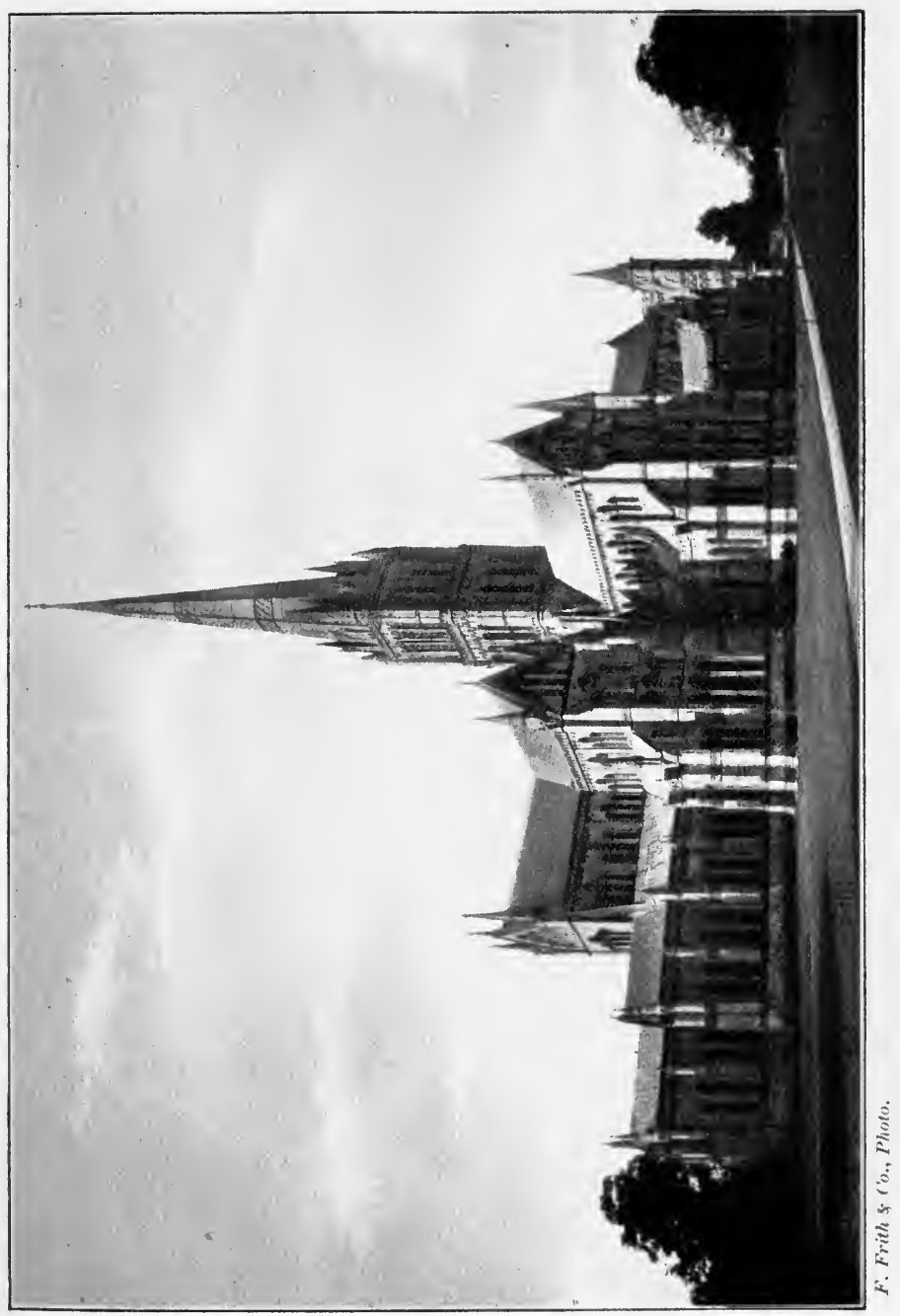



TEXTUAL VARIATIONS OF THE MANUSCRIPTS 



\section{TEXTUAL VARIATIONS}

The Call (p. 9):

4. I have adopted the reading of B. Ed. 1633 by a manifest error reads, And such a.

Providence (p. 79):

102. For furres $B$. reads furre.

Church-Rents and Schismes (p. 105):

$\therefore$ In the title B. reads Church-Rents or Schisms.

1. For chair B. reads place.

18. For faded B. reads vaded.

JUSTICE (p. 117):

10. For tort'ring B. reads torturing.

Businesse (p. 139):

29. For space B. reads spare.

The Pulley (p. 149):

3. For him B. reads his.

The Familie (p. 185):

3. For pulling $B$. reads puling.

The Size (p. 193):

5. For springs $\mathrm{B}$. reads strings.

JUSTICE (p. 253):

1. For thy B. reads $m y$.

Affuction (p. 273):

12. For prick B. reads pink.

The Guimpse (p. 289):

5. For for B. reads to. 
HoMe (p. 325):

On p. 570 of the Rawlinson Manuscript 213, in the Bodleian Library, stanzas i, xi, and xii of this poem are given, the twelfth stanza alone having the refrain.

The Dawning (p. 333):

9. For dost B. reads doe.

Vertue (p. 335):

7. For its B. reads his.

The Church Militant (p. 359):

11. For this line W. reads :

Thou didst rise early for to plant this vine.

16. For this line W. reads :

All emblems which thy Darling doth improve.

20. For from W. reads to.

32. For allows W. reads gives them.

33. For depart W. reads be gone.

49. For this line W. reads :

Thence into Greece she fled, where curious Arts.

52. For fisher's net W. reads fisher-nett.

59. For And spent W. reads Spending.

60-62. For these lines W. reads :

Before the other two were in their prime:

From Greece to Rome she went, subduing those

Who had subdued all the world for foes.

64. For hath W. reads had.

76. For tune W. reads cleanse.

78. For did erect her throne W. reads took possession. 
104. For Journeying W. reads Coasting.

123. For poore $\mathrm{W}$. reads small.

133. For both W. reads in.

137. For the second to $\mathrm{W}$. reads so.

148. For affiction W. reads affictions.

151. For trimme $\mathrm{W}$. reads spruse.

157. For Onely the West W. reads Europe alone, but this is then erased.

160. For this single line $W$. reads the following three:

Traditions are accounts without our host.

They who rely on them must reckon twice,

When written Truths shall censure man's devise.

168. For had more of W. reads was liker.

180. For free dispensings W. reads dispensations.

190. B. omits his.

193. For finely work each W. reads both kings and many a.

194. For into W. reads unto.

198. For and W. reads or.

201-204. For these lines $W$. reads:

Who brought his doctrines and his deeds from Rome:

But when they were unto the Sorbon come,

The waight was such they left the doctrines there,

Shipping the vices onely for our sphere.

229. For yeare $\mathrm{W}$. reads day.

232. For proportions W. reads proportion.

248. For times W. reads time.

256. For the second our B. and W. read her.

258. For But lends W. reads Lendeth.

267. For the W. reads their. 
271-273. For these lines $W$. reads:

Like comick lovers ever one way runn, Thus also sinne and darknes constantly Follow the Church and sunn where ere they fly.

L'Envoy (p. 381):

2. For warre W. reads warrs.

4. B. omits in.

11. For say W. reads speak.

17, 18. W. omits these lines. 


\section{INDEX TO POEMS}





\section{TITLES ALPHABETICALLY ARRANGED}

Aaron, III, 11.

Affliction, II, 247, 339, III, $269,271,273$.

Agonie, III, 153.

To All Angels and Saints, II, 163.

The Altar, II, 121.

Anagram, III, 165.

On an Anchor-Seal, III, 399.

The Answer, II, 351.

Antiphon, II, 107, III, 63.

Artillerie, II, 361.

Assurance, III, 225.

Avarice, III, 113.

The Bag, III, 157.

The Banquet, III, 53.

H. Baptisme, II, 191, 193.

Bitter-Sweet, III, 251.

The British Church, III, 101.

The Bunch of Grapes, III, 215.

Businesse, III, 139.

The Call, III, 9.

Charms and Knots, II, 211.

Christmas, II, 167.

Church-Floore, III, 167.

Church-Lock and Key, II, 301.

The Church Militant, III, 359.

Church-Monuments, II, 201.

Church-Musick, II, 199.

The Church-Porch, II, 15.

Church-Rents and Schismes, III, 105.

Clasping of Hands, III, 37.

The Collar, III, 211.

H. Communion, II, 195, III, 383.

Complaining, III, 267.

Confession, III, 259.

Conscience, III, 229.

Constancie, III, 119.

Content, II, 353.

The Convert, III, 397.

The Crosse, III, 231.

Lord Danvers, III, 423.

Sir John Danvers, III, 421.

The Dawning, III, 333.

Death, II, 263.

Decay, III, 115.

Dedication, II, ix.

Deniall, II, 297.

Dialogue, II, 369.

A Dialogue-Antheme, III, 343.

The Discharge, III, 187.

Discipline, III, 297.

Divinitie, III, 97.

To John Donne, D. D., III, 401.

Dooms-Day, II, 267.

Dotage, III, 137.

Dulnesse, III, 207.

Easter, II, 153.

Easter Wings, II, 335.

The Elixer, II, 99.

Employment, II, 103, 347.

L'Envoy, III, 381, 431.

Even-Song, III, 59, 391.

Faith, II, 233.

'The Familie, III, 185.

The Flower, III, 305.

The Foil, III, 123.

The Forerunners, III, 817.

Frailtie, II, 359. 
Giddinesse, III, 129.

The Glance, III, 331.

The Glimpse, III, 289.

Gloria to Psalm XXIII, III, 419.

Good Friday, II, 149.

Grace, II, 311.

Gratefulnesse, III, 41.

Grief, III, 323.

Grieve not the Holy Spirit, \&c., III, 255.

Heaven, II, 273.

The Holdfast, III, 17.

Home, III, 325.

Hope, III, 203.

Humilitie, II, 239.

A True Hymne, III, 27.

Inscription, III, 75.

The Invitation, III, 49.

Jesu, III, 303.

The Jews, III, 109.

Jordan, II, 87, 91.

Joseph's Coat, III, 301.

Judgement, II, 271.

Justice, III, 117, 253.

The Knell, III, 393.

Lent, II, 171.

Life, III, 321.

Longing, III, 281.

Love, II, 83, 401, III, 387.

Love-Joy, III, 163.

Love Unknown, III, 179.

Man, II, 215.

Man's Medley, III, 125.

Marie Magdalene, III, 151.

Mattens, II, 285.

The Method, III, 197.

Miserie, II, 251.

Mortification, II, 259.

Nature, II, 303.
Obedience, II, 385.

The Odour, III, 23.

An Offering, II, 393.

Our Life is Hid, \&c., II, 283.

Paradise, III, $3 \dot{9}$.

A Paradox, III, 403.

A Parodie, III, 293.

Peace, II, 377.

The Pearl, II, 381.

Perseverance, III, 395.

The Pilgrimage, III, 237.

The Posie, III, 29.

Praise, II, 95, 397, III, 45.

Prayer, II, 181, 183.

The Priesthood, II, 373.

Providence, III, 79.

'The 23 Psalme, III, 19.

Psalms, III, 407, 410, 411, 413, 415.

The Pulley, III, 149.

Queene of Bohemia, III, 425.

The Quidditie, II, 97.

The Quip, III, 33.

Redemption, II, 237.

Repentance, II, 305.

The Reprisall, II, 293.

The Rose, II, 389.

The Sacrifice, II, 123.

Saints, vide Angels.

Schismes, vide Church-Rents.

H. Scriptures, II, 187.

The Search, III, 219.

Self-Condemnation, III, 111.

Sepulchre, III, 155.

Sighs and Grones, III, 277.

Sinne, II, 229, 231.

The Sinner, II, 295.

Sinnes Round, III, 143.

Sion, III, 265.

The Size, III, 193.

The Sonne, III, 161.

Sonnets to his Mother, II, 79. 
The Starre, II, 365. The Storm, III, 263.

Submission, III, 205.

Sunday, II, 175.

Superliminare, II, 119.

The Temper, II, 313, 315.

The Thanksgiving, II, 287.

Time, III, 339.

Trinitie-Sunday, II, 161, III, 389.
Ungratefulnesse, II, 243.

Unkindnesse, II, 309.

Vanitie, II, 357, III, 133.

Vertue, III, 335.

The Water-Course, III, 147.

Whitsunday, II, 157.

The Windows, III, 15.

The World, II, 225.

A Wreath, II, 319. 



\section{TITLES ARRANGED IN THE TRADI- TIONAL ORDER}

The Dedication, II, ix. The Church-Porch, II, 15. Superliminare, II, 119. The Altar, II, 121. The Sacrifice, II, 123. The Thanksgiving, II, 287. The Reprisall, II, 293. The Agonie, III, 153. The Sinner, II, 295. Good Friday, II, 149. Redemption, II, 237. Sepulchre, III, 155. Easter, II, 153. Easter Wings, II, 335. H. Baptisme, II, 191. Nature, II, 303. Sinne, II, 229. Affliction, II, 247. Repentance, II, 305. Faith, II, 233. Prayer, II, 181. H. Communion, II, 195. Antiphon, II, 107. Love, II, 83.

The Temper, II, 313. The Temper, II, 315. Jordan, If, 87.

Employment, II, 103.

H. Scriptures, II, 187.

Whitsunday, II, 157.

Grace, II, 311.

Praise, II, 95.

Affliction, II, 339.

Mattens, II, 285.

Sinne, II, 231.

Even-Song, III, 59.

Church-Monuments, II, 201. Church-Musick, II, 199.
Church-Lock and Key, II, 301.

The Church Floore, III, 167.

The Windows, III, 15.

Trinitie-Sunday, II, 161.

Content, II, 353.

The Quidditie, II, 97.

Humilitie, II, 239.

Frailtie, II, 359.

Constancie, III, 119.

Affliction, III, 269.

The Starre, II, 365.

Sunday, II, 175.

Avarice, III, 113.

Anagram, III, 165.

To All Angels and Saints, II, 163.

Employment, II, 347.

Deniall, II, 297.

Christmas, II, 167.

Ungratefulnesse, II, 243.

Sighs and Grones, III, 277.

The World, II, 225.

Our Life is Hid, \&c., II, 283.

Vanitie, II, 357.

Lent, II, 171.

Vertue, III, 335.

The Pearl, II, 381.

Affliction, III, 271.

Man, II, 215.

Antiphon, III, 63.

Unkindnesse, II, 309.

Life, III, 321.

Submission, III, 205.

Justice, III, 253.

Charms and Knots, II, 211.

Affliction, III, 273.

Mortification. II, 259.

Decay, III, 115. 
Miserie, II, 251.

Jordan, II, 91.

Prayer, II, 183.

Obedience, II, 385.

Conscience, III, 229.

Sion, III, 265.

Home, III, 325.

The British Church, III, 101.

The Quip, III, 33.

Vanitie, III, 133.

The Dawning, III, 333.

Jesu, III, 303.

Businesse, III, 139.

Dialogue, II, 369.

Dulnesse, III, 207.

Love-Joy, III, 163.

Providence, III, 79.

Hope, III, 203.

Sinnes Round, III, 143.

Time, III, 339.

Gratefulnesse, III, 41.

Peace, II, 377.

Confession, III, 259.

Giddinesse, III, 129.

The Bunch of Grapes, III, 215.

Love Unknown, III, 179.

Man's Medley, III, 125.

The Storm, III, 263.

Paradise, III, 39.

The Method, III, 197.

Divinitie, III, 97.

Grieve Not the Holy Spirit, \&c., III, 255.

The Familie, III, 185.

The Size, III, 193.

Artillerie, II, 361.

Church-Rents and Schismes, III, 105.

Justice, III, 117.

The Pilgrimage, III, 237.

The Holdfast, III, 17.

Complaining, III, 267.

The Discharge, III, 187.

Praise, II, 397.

An Offering, II, 393.

Longing, III, 281.
The Bag, III, 157.

The Jews, III, 109.

The Collar, III, 211.

The Glimpse, III, 289.

Assurance, III, 225.

The Call, III, 9.

Clasping of Hands, III, 37.

Praise, III, 45.

Joseph's Coat, III, 301.

The Pulley, III, 149.

The Priesthood, II, 373.

The Search, III, 219.

Grief, III, 323.

The Crosse, III, 231.

The Flower, III, 305.

Dotage, III, 137.

The Sonne, III, 161.

A True Hymne, III, 27.

The Answer, II, 351.

A Dialogue-Antheme, III, 343.

The Water-Course, III, 147.

Self-Condemnation, III, 111.

Bitter-Sweet, III, 251.

The Glance, III, 331.

The 23 Psalme, III, 19.

Marie Magdalene, III, 151.

Aaron, III, 11.

The Odour, III, 23.

The Foil, III, 123.

The Forerunners, III, 317.

The Rose, II, 389.

Discipline, III, 297.

The Invitation, III, 49.

The Banquet, III, 53.

The Posie, III, 29.

A Parodie, III, 293.

The Elixer, II, 99.

A Wreath, II, 319.V

Death, II, 263.

Dooms-Day, II, 267.

Judgement, II, 271.

Heaven, II, 273.

Love, II, 401.

The Church Militant, III, 359.

L'Envoy, III, 381. 


\section{TITLES ARRANGED IN THE ORDER OF THIS EDITION}

Dedication, II, ix.

Group I: The ChurchPorch.

The Church-Porch, II, 15.

Group II: The Resolve.

Two Sonnets to his Mother, II, 79.

Love, II, 83.

Jordan, II, 87.

Jordan, II, 91.

Praise, II, 95.

The.Quidditie, II, 97.

The Elixer, II, 99.

Employment, II, 103.

Antiphon, II, 107.

Group III: The Church.

Superliminare, II, 119.

The Altar, II, 121.

The Sacrifice, II, 123.

Good Friday, II, 149.

Easter, II, 153.

Whitsunday, II, 157.

Trinitie-Sunday, II, 161.

To All Angels and Saints, II, 163.

Christmas, II, 167.

Lent, II, 171.

Sunday, II, 175.

Prayer, II, 181.

Prayer, II, 183.

The H. Scriptures, II, 187.

H. Baptisme, II, 191.

H. Baptisme, II, 193.

H. Communion, II, 195.

Church-Musick, II, 199.
Church - Monuments, II, 201.

Group IV: Meditation.

Charms and Knots, II, 211.

Man, II, 215.

The World, II, 225.

Sinne, II, 229.

Sinne, II, 231.

Faith, II, 233.

Redemption, II, 237.

Humilitie, II, 239.

Ungratefulnesse, II, 243.

Affliction, II, 247.

Miserie, II, 251.

Mortification, II, 259.

Death, II, 263.

Dooms-Day, II, 267.

Judgement, II, 271.

Heaven, II, 273.

Group V: The InNer Life.

Our Life is Hid, \&c.. II, 283.

Mattens, II, 285.

The Thanksgiving, II, 287.

The Reprisall, II, 293.

The Sinner, II, 295.

Deniall, II, 297.

Church-Lock and Key, II, 301.

Nature, II, 303.

Repentance, II, 305.

Unkindnesse, II, 309.

Grace, II, 311.

The Temper, II, 313. 
The Temper, II, 315.

A Wreath, II, 319.

Group VI: The Crisis.

Easter Wings, II, 335.

Affliction, II, 339.

Employment, II, 347.

The Answer, II, 351.

Content, II, 353.

Vanitie, II, 357.

Frailtie, II, 359.

Artillerie, II, 361.

The Starre, II, 365.

Dialogue, II, 369.

The Priesthood, II, 373.

Peace, II, 377.

The Pearl, II, 381.

Obedience, II, 385 .

The Rose, II, 389.

An Offering, II, 393.

Praise, II, 397.

Love, II, 401.

GrodP VII: The Happy Priest.

The Call, III, 9.

Aaron, III, 11.

The Windows, III, 15.

The Holdfast, III, 17.

The 23 Psalme, III, 19.

The Odour, III, 23.

A True Hymne, III, 27.

The Posie, III, 29.

The Quip, III, 33.

Clasping of Hands, III, 37.

Paradise, III, 39.

Gratefulnesse, III. 41.

Praise, III, 45.

The Invitation, III, 49.

The Banquet, III, 53.

Even-Song, III, 59.

Antiphon, III, 63.

GrotP VIII: BEMERTON STUdy.

To My Successor, III, 75.

Providence, III, 79.
Divinitie, III, 97.

The British Church, III, 101.

Church-Rents and Schismes, III, 105.

The Jews, III, 109.

Self-Condemnation,III,111.

Avarice, III, 113.

Decay, III, 115.

Justice, III, 117.

Constancie, III, 119.

The Foil, III, 123.

Man's Medley, III, 125.

Giddinesse, III, 129.

Vanitie, III, 133.

Dotage, III, 137.

Businesse, III, 139.

Sinnes Round, III, 143.

The Water-Course, III, 147.

The Pulley, III, 149.

Marie Magdalene, III, 151.

The Agonie, III, 153.

Sepulchre, III, 155.

The Bag, III, 157.

The Sonne, III, 161.

Love-Joy, III, 163.

Anagram, III, 165.

The Church-Floore, III, 167.

Group IX: Restuessness.

Love Unknown, III, 179.

The Familie, III, 185.

The Discharge, III, 187.

The Size, III, 193.

The Method, III, 197.

Hope, III, 203.

Submission, III, 205.

Dulnesse, III, 207.

The Collar, III, 211.

The Bunch of Grapes, III, 215.

The Search, III, 219.

Assurance, III, 225.

Conscience, III, 229.

The Crosse, III, 231.

The Pilgrimage, III, 237. 


\section{INDEX}

Group X: Suffering. Bitter-Sweet, III, 251. Justice, III, 253.

Grieve Not the Holy Spirit, \&c., III, 255.

Confession, III, 259.

The Storm, III, 263.

Sion, III, 265.

Complaining, III, 267.

Affliction, III, 269.

Affliction, III, 271.

Affliction, III, 273.

Sighs and Grones, III, 277.

Longing, III, 281.

The Glimpse, III, 289.

A Parodie, III, 293.

Discipline, III, 297.

Joseph's Coat, III, 301.

Jesu, III, 303.

The Flower, III, 305.

Group XI: Death.

The Forerunners, III, 317.

Life, III, 321.

Grief, III, 323.

Home, III, 325.

The Glance, III, 331.

The Dawning, III, 333.

Vertue, III, 335.

Time, III, 339.

A Dialogue-Antheme, III, 343.
Group XII: AdDitional AND Doubtrul Poems.

The Church-Militant, III, 359.

L'Envoy, III, 381.

H. Communion, III, 383.

Love, III, 387.

Trinitie-Sunday, III, 389.

Even-Song, III,, 391.

The Knell, III, 393.

Perseverance, III, 395.

The Convert, III, 397.

On an Anchor-Seal, III, 399.

To John Donne, D. D., III, 401.

A Paradox III, 403.

Psalm II, III, 407.

Psalm III, III, 410.

Psalm IV, III, 411.

Psalm VI, III, 413.

Psalm VII, III, 415.

Gloria to Psalm XXIII, III, 419.

On Sir John Danvers, III, 421.

On Lord Danvers, III, 423.

To the Queene of Bohemia, III, 425.

L'Envoy, III, 431. 



\section{INDEX OF FIRST LINES}

A broken Altar, Lord, thy servant reares, II, 121.

Ah my deare angrie Lord, III, 251.

Alas, poore Death, where is thy glorie? III, 343.

All after pleasures as I rid one day, II, 167.

Almightie Judge, how shall poore wretches brook, II, 271.

Almightie Lord, who from thy glorious throne, III, 359.

Although the Cross could not Christ here detain, HII, 401. And art thou grieved, sweet and sacred Dove, III, 255.

As he that sees a dark and shadie grove, II, 191.

As I one ev'ning sat before my cell, II, 361 .

As men, for fear the starres should sleep and nod, III, 97.

As on a window late I cast my eye, III, 163.

Awake sad heart, whom sorrow ever drowns! III, 333.

Away despair ! My gracious Lord doth heare, III, 157.

A wreathed garland of deserved praise, II, 319.

Blest be the God of love, III, 59 .

Blest Order, which in power dost so excell, II, 373.

Brave rose, (alas!) where art thou ? In the chair, III, 105.

Bright soule, of whome if any countrey knowne, III, 425.

Bright spark, shot from a brighter place, II, 365.

Broken in pieces all asunder, III, 273.

Busie enquiring heart, what wouldst thou know? III, 187.

But that Thou art my wisdome, Lord, III, 205.

Canst be idle ? Canst thou play, III, 139.

Come away, II, 267.

Come, bring thy gift. If blessings were as slow, II, 393 .

Come Lord, my head doth burn, my heart is sick, III, 325.

Come, my Way, my Truth, my Life, III, 9.

Come ye hither all whose taste, III, 49.

Content thee, greedie heart, III, 193.

Deare Friend, sit down, the tale is long and sad, III, 179.

Death, thou wast once an uncouth hideous thing, II, 263.

Do not beguile my heart, III, 267.

False glozing pleasures, casks of happinesse, III, 137.

Full of rebelion, I would die, II, 303.

Having been tenant long to a rich Lord, II, 237. 
Heark, how the birds do sing, III, 125.

He that is one, III, 389.

He that is weary, let him sit, II, 103.

Holinesse on the head, III, 11.

How are my foes increasèd, Lord! III, 410.

How fresh, O Lord, how sweet and clean, III, 305.

How should I praise thee, Lord! How should my rymes, II, 315.

How soon doth man decay! II, 259.

How sweetly doth My Master sound! My Master, III, 23.

How well her name an army doth present, III, 165.

I blesse thee, Lord, because I grow, III, 39.

I cannot ope mine eyes, II, 285.

I cannot skill of these thy wayes, III, 253.

If as a flowre doth spread and die, II, 347.

If as the windes and waters here below, III, 263.

If ever tears did flow from eyes, III, 397.

If thou chance for to find, III, 75.

If we could see below, III, 123 .

I gave to Hope a watch of mine; but he, III, 203.

I have consider'd it, and finde, II, 293.

I joy, deare Mother, when I view, III, 101.

I know it is my sinne which locks thine eares, II, 301.

I know the wayes of learning, both the head, II, 381.

I made a posie while the day ran by, III, 321 .

Immortall Heat, $\mathrm{O}$ let thy greater flame, II, 85.

Immortall Love, authour of this great frame, II, 83.

I saw the Vertues sitting hand in hand, II, 239.

I struck the board, and cry'd, No more, III, 211.

It cannot be. Where is that mightie joy, II, 313.

I threatned to observe the strict decree, III, 17.

I travell'd on, seeing the hill where lay, III, 237.

Jesu is in my heart, his sacred name, III, 303.

Joy, I did lock thee up, but some bad man, III, 215.

Kill me not ev'ry day, III, 269.

King of Glorie, King of Peace, II, 397.

King of glorie, King of peace, III, 381.

Let all the world in ev'ry corner sing, III, 63.

Let forrain nations of their language boast, III, 161.

Let wits contest, III, 29.

Listen, sweet Dove, unto my song, II, 157.

Lord, hear me when I call on Thee, III, 411.

Lord, how can man preach thy eternall word? III, 15. 
Lord, how couldst thou so much appease, II, 233.

Lord, how I am all ague when I seek, II, 295.

Lord, I confesse my sinne is great, II, 305.

Lord, in my silence how do I despise, II, 359.

Lord, I will mean and speak thy praise, III, 45.

Lord, let the Angels praise thy name, II, 251.

Lord, make me coy and tender to offend, II, 309.

Lord, my first fruits present themselves to thee, II, ix.

Lord, thou art mine, and I am thine, III, 37.

Lord, who createdst man in wealth and store, II, 335.

Lord, who hast form'd me out of mud, II, 161.

Lord, with what bountie and rare clemencie, II, 243.

Lord, with what care hast thou begirt us round! II, 231.

Lord, with what glorie wast thou serv'd of old, III, 265 .

Love bade me welcome; yet my soul drew back, II, 401 .

Love built a stately house; where Fortune came, II, 225.

Mark you the floore? That square and speckled stone, III, 167.

Meeting with Time, slack thing, said I, III, 339.

Money, thou bane of blisse and sourse of wo, III, 113.

My comforts drop and melt away like snow, II, 351 .

My God, a verse is not a crown, II, 97.

My God, if writings may, II, 385.

My God, I heard this day, II, 215.

My God, I read this day, II, 247.

My God the poore expressions of my Love, III, 395.

My God, where is that antient heat towards thee, II, 79.

My heart did heave, and there came forth, O God! III, 271.

My joy, my life, my crown! III, 27.

My stock lies dead, and no increase, II, 311.

My words and thoughts do both expresse this notion, II, 283.

Not in rich furniture or fine array, II, 195.

O blessed bodie! Whither art thou thrown? III, 155.

$\mathrm{O}$ day most calm, most bright, II, 175 .

$O$ do not use me, III, 277 .

$O$ dreadfull Justice, what a fright and terrour, III, 117.

Of what an easie quick accesse, II, 183.

O gratious Lord, how shall I know, III, 383.

Oh all ye who passe by, whose eyes and minde, II, 123.

Oh Book! Infinite sweetnesse! Let my heart, II, 187.

Oh glorious spirits, who after all your bands, II, 163.

Oh King of grief ! A title strange, yet true, II, 287.

Oh that I knew how all thy lights combine, II, 189.

$\mathrm{Oh}$, what a thing is man! How farre from power, III, 129. 
O my chief good, II, 149.

O sacred Providence, who from end to end, III, 79.

O spitefull bitter thought! III, 225.

O that I could a sinne once see! II, 229.

$O$ what a cunning guest, III, 259.

O who will give me tears? Come all ye springs, III, 323.

O who will show me those delights on high, II, 273.

Passe not by, III, 421.

Peace mutt'ring thoughts, and do not grudge to keep, II, 353.

Peace pratler, do not lowre! III, 229.

Philosophers have measur'd mountains, III, 153.

Poore heart, lament, III, 197.

Poore nation, whose sweet sap and juice, III, 109.

Poore silly soul, whose hope and head lies low, II, 357.

Praised be the God of love, II, 107.

Prayer the Churches banquet, Angel's age, II, 181.

Presse me not to take more pleasure, II, 389 .

Rebuke me not in wrath, O Lord, III, 413.

Rise, heart, thy Lord is risen. Sing his praise, II, 153.

Sacred marble, safely keepe, III, 423.

Save me, my Lord, my God, because, III, 415.

Shine on, Majestick soule, abide, III, 431.

Since, Lord, to thee, II, 193.

Sorrie I am, my God, sorrie I am, III, 143.

Soul's joy, when thou art gone, III, 293.

Sure, Lord, there is enough in thee to dry, II, 81.

Sweet day, so cool, so calm, so bright, III, 335 .

Sweetest of sweets, I thank you! When displeasure, II, 199.

Sweetest Saviour, if my soul, II, 369.

Sweet Peace, where dost thou dwell? I humbly crave, II, 377.

Sweet were the dayes when thou didst lodge with Lot, III, 115.

Teach me, my God and King, II, 99.

The Bell doth tolle, III, 393.

The Day is spent, and hath his will on mee, III, 391.

The fleet Astronomer can bore, III, 133.

The God of love my shepherd is, III, 19.

The harbingers are come. See, see their mark! III, 317.

The merrie world did on a day, III, 33.

Thou art too hard for me in Love, III, 387.

Thou that hast giv'n so much to me, III, 41.

Thou who condemnest Jewish hate, III, 111.

Thou who dost dwell and linger here below, III, 147.

Thou, whom the former precepts have, II, 119. 
Thou whose sweet youth and early hopes inhance, II, 15.

Throw away thy rod, III, 297.

To Father, Son, and Holy Ghost, III, 419

To write a verse or two is all the praise, II, 95.

Welcome, deare feast of Lent! Who loves not thee, II, 171 .

Welcome sweet and sacred cheer, III, 53.

What doth this noise of thoughts within my heart, III, 185.

What is this strange and uncouth thing! III, 231.

When blessed Marie wip'd her Saviour's feet, III, 151.

When first my lines of heav'nly joyes made mention, II, 91 .

When first thou didst entice to thee my heart, II, 339.

When first thy sweet and gracious eye, III, 331.

When God at first made man, III, 149.

When my dear Friend could write no more, III, 399.

When my devotions could not pierce, II, 297.

While that my soul repairs to her devotion, II, 201.

Whither away delight? III, 289.

Whither, O, whither art thou fled, III, 219.

Who is the honest man, III, 119.

Who reade a chapter when they rise, II, 211.

Who says that fictions onely and false hair, II, 87.

Why are the heathen swell'd with rage, III, 407.

Why do I languish thus, drooping and dull, III, 207.

With sick and famisht eyes, IfI, 281.

Wounded I sing, tormented I indite, III, 301.

You who admire yourselves because, III, 403. 
Che finergide presig

Electrotyped and printed by H.O. Houghton \& Co. Cambridge, Mass., U. S. A. 






\section{PLEASE DO NOT REMOVE CARDS OR SLIPS FROM THIS POCKET}

\section{UNIVERSITY OF TORONTO LIBRARY}

PR Herbert, George 3507 English works

A2P3 v.3 


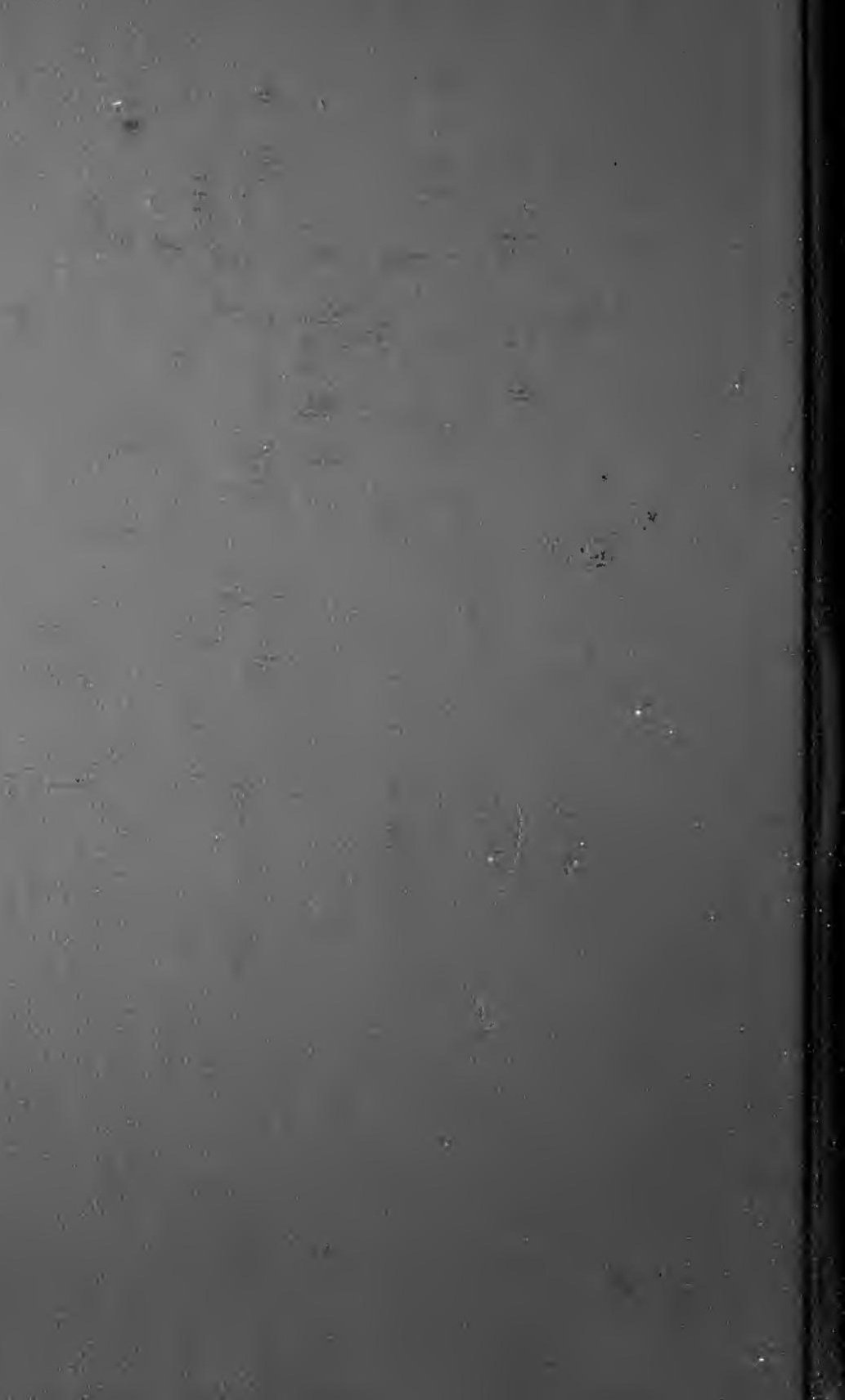

\section{ve.}
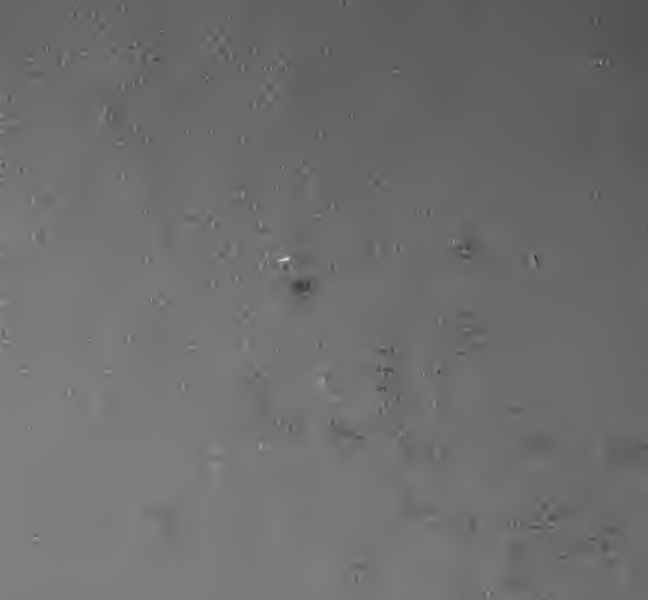